Universidade de São Paulo

Escola Superior de Agricultura "Luiz de Queiroz"

Caracterização fisiológica de plântulas de soja submetidas a diferentes tratamentos químicos

Maíra Paes Lacerda

Dissertação apresentada para obtenção

do título de Mestra em Ciências. Área de

concentração: Fitotecnia

Piracicaba

2014 
Maíra Paes Lacerda

Engenheira Agrônoma

\section{Caracterização fisiológica de plântulas de soja submetidas a diferentes tratamentos} químicos

Orientador:

Prof. Dr. DURVAL DOURADO NETO

Dissertação apresentada para obtenção do título de Mestra em Ciências. Área de concentração: Fitotecnia

\section{Piracicaba}




\section{Dados Internacionais de Catalogação na Publicação}

DIVISÃO DE BIBLIOTECA - ESALQ/USP

\section{Lacerda, Maíra Paes}

Caracterização fisiológica de plântulas de soja submetidas a diferentes tratamentos químicos / Maíra Paes Lacerda.- - Piracicaba, 2014.

95 p. : il.

Dissertação (Mestrado) - - Escola Superior de Agricultura “Luiz de Queiroz”, 2014.

Bibliografia.

1. Efeito fisiológico 2. Enzima antioxidante 3. Catalase 4. Germinação 5. Emergência 6. Vigor I. Título

CDD 633.34

L131C

"Permitida a cópia total ou parcial deste documento, desde que citada a fonte - 0 autor" 
Ao meu pai Nuno Álvarez Luz Lacerda (in memorian) inspiração para meus passos, à minha mãe Rosemeire Marques Paes, exemplo de dedicação e perseverança, e à minha irmã, Maria Emília.

Dedico 


\section{AGRADECIMENTOS}

A Deus, por guiar meus passos e iluminar meus pensamentos.

À Escola Superior de Agricultura "Luiz de Queiroz" da Universidade de São Paulo, Departamento de Produção Vegetal e Programa de Pós-Graduação em Fitotecnia, pela oportunidade de realizar o mestrado.

Ao Professor Dr. Durval Dourado Neto, pela orientação, aprendizado, confiança e apoio ao longo dos últimos anos.

Ao Engenheiro Agrônomo Dr. Marco Antônio Tavares Rodrigues, o qual, através dos ensinamentos e da confiança depositada ao longo de minha trajetória, contribuiu significativamente para despertar meu interesse pelos temas discutidos neste trabalho.

Ao Grupo de Fisiologia Aplicada a Sistemas de Produção - GFASP, principalmente Wendy van der Geest, Thamires Buranello e Ana Paula Schwantes, pela amizade e valiosa ajuda na condução dos experimentos.

À amiga Engenheira Agrônoma Karla Vilaça (M.Sc.), pela amizade e contribuição imprescindível ao longo de todo o trabalho.

Ao Professor Dr. Evandro Binotto Fagan, do Centro Universitário de Patos de Minas (UNIPAM), pelo auxílio nas discussões e ao amigo Tiago Tezotto (M.Sc.), pelas contribuições na definição e discussão das metodologias utilizadas.

Aos funcionários do Departamento de Produção Vegetal da ESALQ-USP que contribuíram para a realização deste trabalho.

À Engenheira Agrônoma Helena M. C. P. Chamma (Laboratório de Sementes Departamento de Produção Vegetal) pela constante disponibilidade em ajudar e pelas recomendações na condução dos experimentos.

Ao Professor Dr. Silvio Moure Cicero e ao Engenheiro Agrônomo Francisco Guilhien Gomes Júnior, pelo auxílio no Laboratório de Análise de Imagens do Departamento de Produção Vegetal da ESALQ-USP.

Ao Professor Dr. José Otávio Machado Menten e à Maria Heloísa D. Moraes (Laboratório de Patologia de Sementes - Departamento de Fitopatologia e Nematologia), pela realização dos testes de sanidade das sementes.

Ao Professor Dr. Ricardo Antunes Azevedo e à Manuella Nóbrega Dourado, pela contribuição e análises realizadas no Laboratório de Genética e Bioquímica de Plantas do Departamento de Genética (ESALQ-USP).

À Luciane aparecida Lopes Toledo, pela grande ajuda em todos os momentos. 
À Professora Dra. Simone Rodrigues da Silva, pelo apoio durante o início do curso de mestrado.

À Bibliotecária Súlvia Zinsly e aos demais funcionários, pela colaboração na padronização e auxílio na submissão desta Dissertação.

Aos colegas do Departamento de Registro da BASF S.A., sobretudo Tadashi Yotsumoto, Fábio Pevide e Moacir Hellmann, por possibilitarem o andamento e conclusão deste trabalho, pelo apoio e amizade.

Aos Engenheiros Agrônomos Renan Teixeira (BASF S.A.) e Sergio Zanon, pelo auxílio no tratamento das sementes.

Ao Engenheiro Agrônomo Dr. Reinaldo Bonnecarrère (BASF S.A.), pelas sugestões e discussões acerca dos resultados obtidos.

À Maga Donaire, por estarem sempre por perto e pelos momentos de alegria.

Ao Bruno Cocco Lago, cuja presença torna o caminho mais fácil, pelo apoio e compreensão.

À minha família, minha mãe, minha irmã, meus avós e tios, pelo grande incentivo, amor, compreensão, constante apoio e paciência ao longo destes dois anos. 


\section{SUMÁRIO}

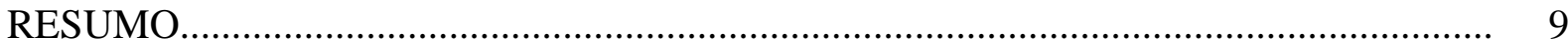

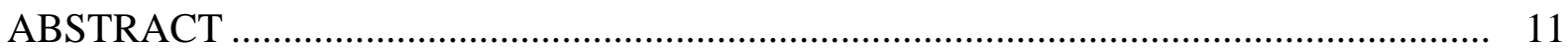

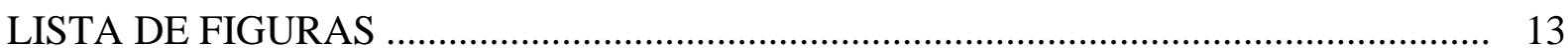

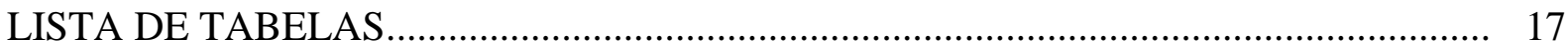

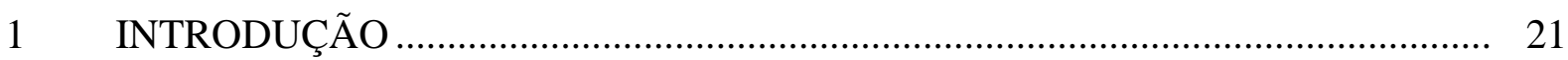

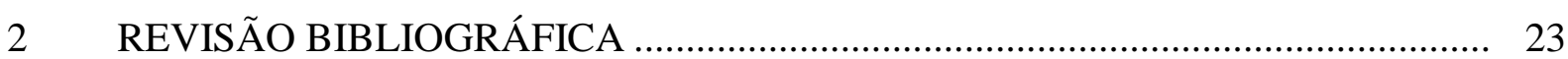

2.1 Produção mundial de soja ............................................................................... 23

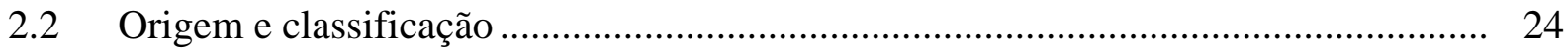

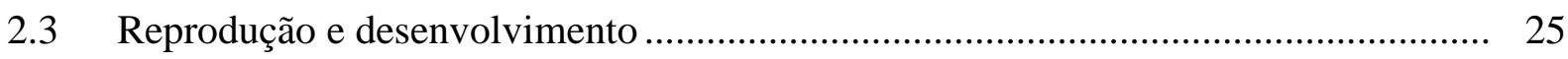

2.4 Vigor e estabelecimento da cultura no campo ................................................... 27

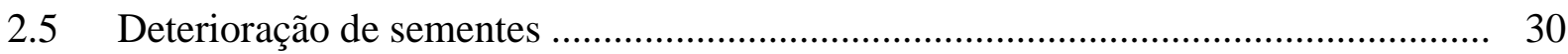

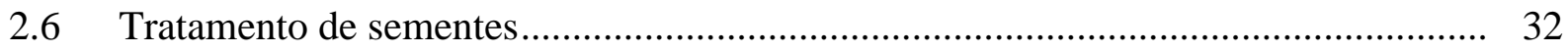

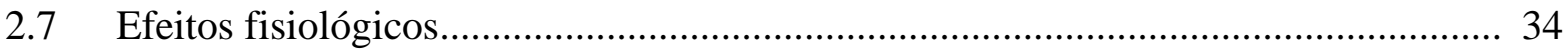

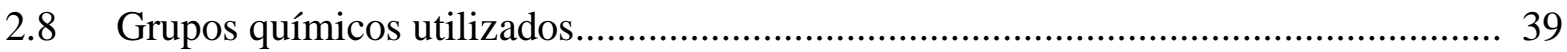

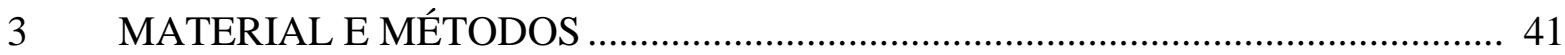

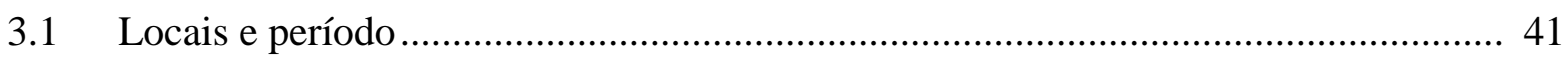

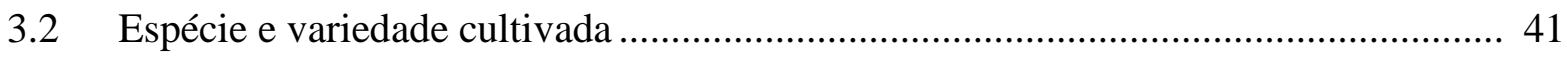

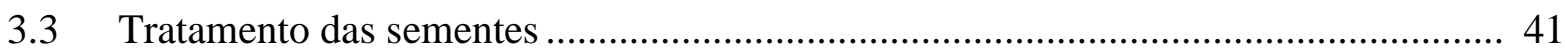

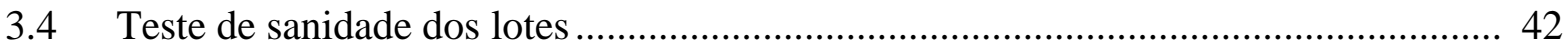

3.5 Determinação do teor de água $\quad 42$

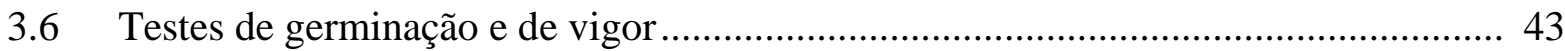

3.7 Valor SPAD e teor de clorofila da folha ............................................................. 46

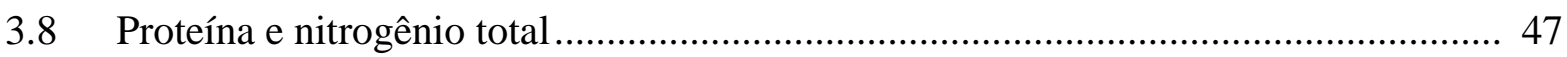

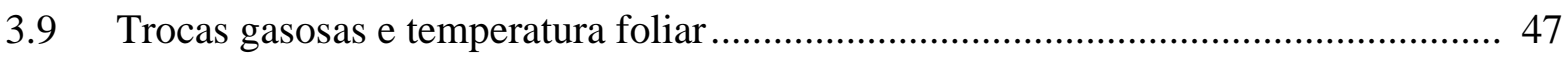

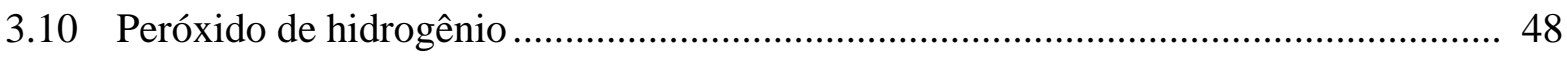

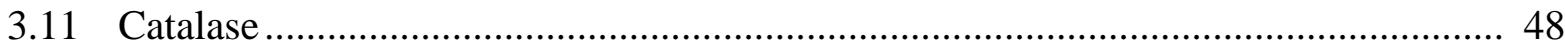

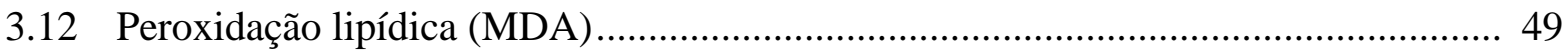

3.13 Delineamento experimental e análise estatística.................................................... 49

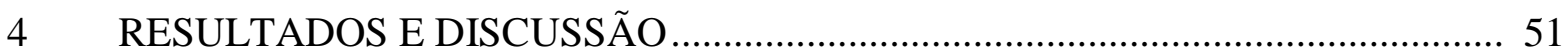

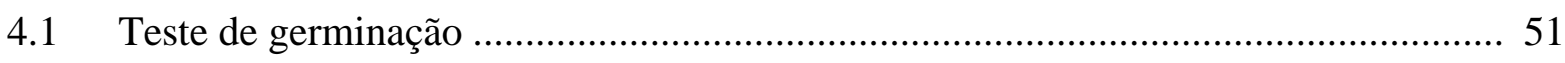

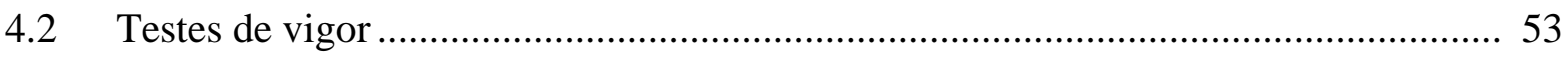

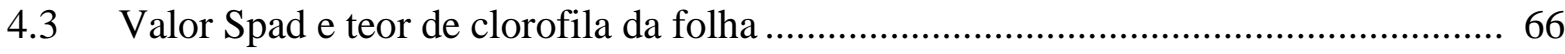




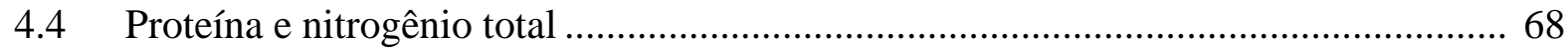

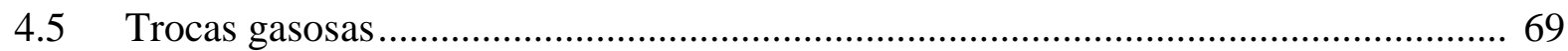

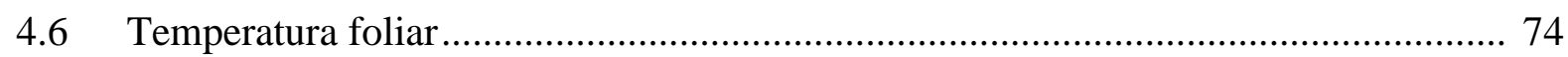

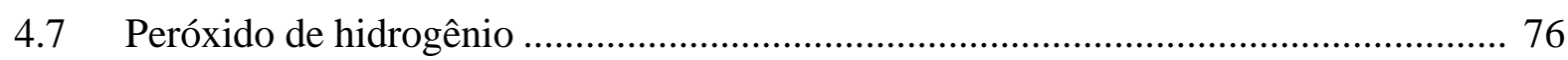

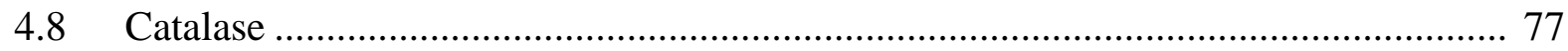

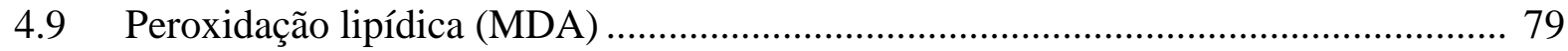

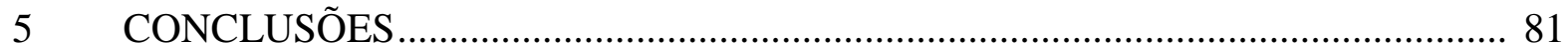

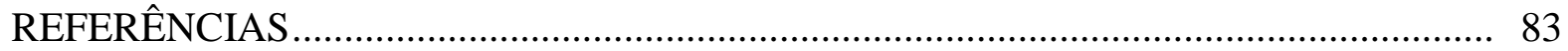

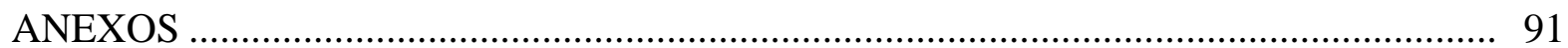




\section{RESUMO}

\section{Caracterização fisiológica de plântulas de soja submetidas a diferentes tratamentos}

\section{químicos}

Com o objetivo de avaliar o desempenho de diferentes doses e produtos fitossanitários utilizados no tratamento de sementes de soja, foi efetuada a caracterização do efeito fisiológico na germinação e no desenvolvimento das plântulas por intermédio dos testes de germinação e de vigor (índice de velocidade de germinação, envelhecimento acelerado, comprimento e massa de matéria seca de plântula, teste de frio e análise computadorizada de imagem) em laboratório, além da determinação do teor de clorofila (por intermédio do valor SPAD), fotossíntese líquida, condutância estomática, transpiração, temperatura foliar, conteúdo de peróxido de hidrogênio, peroxidação de lipídios, atividade da catalase (enzima antioxidante), e teor de proteína e de nitrogênio total. Com base nos resultados obtidos observou-se que todos os tratamentos apresentaram desempenho satisfatório no que diz respeito à germinação. Não se observaram diferenças em termos de índice de velocidade de germinação, envelhecimento acelerado, comprimento e massa de matéria seca de raiz, índice de vigor e de crescimento (análise de imagem) e peroxidação de lipídeos. O tratamento com Fipronil + Piraclostrobina + Tiofanato Metílico apresentou tendência de melhor desempenho em termos de comprimento de parte aérea, enquanto o tratamento Controle apresentou tendência de melhor desempenho, mas não diferiu dos tratamentos: Fipronil + Piraclostrobina + Tiofanato Metílico, Fluxapiroxade e Piraclostrobina em termos de massa de matéria seca de parte aérea. Os tratamentos Fipronil e Fluxapiroxade apresentaram melhor desempenho que o Controle, em termos de relação massa de matéria seca de raiz e de parte aérea. $\mathrm{O}$ tratamento com Fipronil apresentou melhor tendência de desempenho pelo teste de frio e juntamente com Fipronil + Piraclostrobina + Tiofanato Metílico e Fluxapiroxade apresentou desempenho melhor que o Controle no de índice de uniformidade. A Piraclostrobina apresentou desempenho melhor que o Controle em termos de teor de clorofila, fotossíntese líquida e temperatura foliar, enquanto o tratamento com Fipronil foi melhor que o Controle e os demais tratamentos em termos de condutância estomática e transpiração. Os tratamentos com Fipronil e Piraclostrobina apresentaram desempenho melhor que o Controle, em termos de conteúdo de peróxido de hidrogênio e os tratamentos com Fipronil + Piraclostrobina + Tiofanato Metílico e Fluxapiroxade e Piraclostrobina apresentaram desempenho melhor que o Controle, em termos da atividade da catalase. O Fluxapiroxade (50 g por $100 \mathrm{~kg}$ de sementes) apresentou melhor desempenho, mas não diferiu do Controle e dos tratamentos com Fipronil, Fluxapiroxade ( 25 e 75 g por $100 \mathrm{~kg}$ de sementes) e Piraclostrobina em termos do teor de proteína e nitrogênio total. Com os resultados apresentados, conclui-se que não houve prejuízo ao vigor das plântulas quando realizado o tratamento de sementes. Além disso, podese concluir que esta constitui prática agronômica eficiente não só no que diz respeito ao controle de doenças e pragas, mas também apresenta benefícios no que diz respeito à fisiologia das plântulas de soja, sobretudo para tratamento realizado com estrobilurinas. Esses benefícios podem favorecer um melhor estabelecimento das plântulas no campo.

Palavras-chave: Efeito fisiológico; Enzima antioxidante; Catalase; Germinação; Emergência; Vigor 


\section{ABSTRACT \\ Physiological characterization of soybean seedlings under different chemical treatments}

This study aimed to evaluate the physiological effects of soybean seed treatment with different pesticides and doses on germination and seedling development. Germination and vigor tests, such as speed of germination index, accelerated aging, length and dry weight of seedling, cold test and computerized image analysis were performed in the laboratory, besides the determination of chlorophyll content (SPAD value), net photosynthesis, stomatal conductance, leaves transpiration and temperature, content of hydrogen peroxide, lipid peroxidation, catalase (an antioxidant enzyme) activity, protein and total nitrogen. The results obtained revealed that all treatments showed satisfactory performance in germination. No differences in terms of speed index, accelerated aging, root length and dry weight, vigor and growth index (image analysis) and lipid peroxidation were observed. Treatment with Fipronil + Pyraclostrobin + Methyl Tiophanate tended to perform better in terms of shoot, while control treatment tended to perform better, but did not differ from treatments with Fipronil + Pyraclostrobin + Methyl Tiophanate, Fluxapyroxad and Pyraclostrobin in terms of shoot dry matter. Fipronil and Fluxapyroxad treatments performed better than the control in terms of relationship between root and shoot dry weight. Treatment with Fipronil showed better performance trend for the cold test and along with Fipronil + Pyraclostrobin + Methyl Tiophanate and Fluxapyroxad performed better than control on the uniformity index. Pyraclostrobin showed better performance than the control in terms of chlorophyll content, net photosynthesis and leaf temperature, whereas treatment with Fipronil was better than the control and other treatments in terms of stomatal conductance and transpiration. Treatments with Fipronil and Pyraclostrobin performed better than the control in terms of content of hydrogen peroxide and treatments with Fipronil + Pyraclostrobin + Methyl Tiophanate, Fluxapyroxad and Pyraclostrobin performed better than the control in terms of catalase activity. Fluxapyroxad (50 g per $100 \mathrm{~kg}$ of seeds) performed better, but did not differ from control, Fipronil, Fluxapyroxad (25 and $75 \mathrm{~g}$ per $100 \mathrm{~kg}$ of seeds) and Pyraclostrobin in terms of protein content and total nitrogen. With the results presented, we conclude that there was no damage to seedling vigor when seed treatment was applied. Furthermore, it can be concluded that this is an efficient agronomic practice with regard to the control of diseases and pests and it also has benefits to the physiology of soybean seedlings, mainly when treatment is done with Strobilurins. These benefits can favorable to a better seedling establishment in the field.

Keywords: Physiological effect; Antioxidant enzyme; Catalase; Germination; Emergence; Vigor 


\section{LISTA DE FIGURAS}

Figura 1 - VALORES MÉDIOS (LOSANGOS), MÍNIMOS, PRIMEIRO QUARTIL, MEDIANOS, TERCEIRO QUARTIL E MÁXIMOS REFERENTES AO TESTE DE GERMINAÇÃO, (A) AOS $4\left(\mathrm{G}_{4}, \%\right)$ E (B) AOS $7\left(\mathrm{G}_{7}, \%\right)$ DIAS APÓS A SEMEAdura . Laboratório de anÁlise de sementes. Departamento de ProduÇão Vegetal. Escola SuPERIOR soja Agricultura “Luiz de QUeIroz”. Universidade de São PaUlo. 2013 .......52

Figura 2 - VAlores mÉdios REFERENTES AO ÍNDICE DE VELOCIDAde DE GERMinaÇão (IVG, PlÂNTUlas.dia ${ }^{-1}$ ) DE soja. Laboratório de anÁlise de SEMENTES. Departamento de Produção Vegetal. Escola SuPERIor de Agricultura “Luiz de QueIroz”. Universidade de SÃo PAULO. 2013.

FIGURA 3 - RESULTADOS: VALORES MÉDIOS (LOSANGOS), MÍNIMOS, PRIMEIRO QUARTIL, MEDIANOS, TERCEIRO QUARTIL E MÁXIMOS REFERENTES À GERMINAÇÃo (EA, \%) DE SEMENTES DE SOJA APÓS O 'ENVELHECIMENTO ACELERADO' (TESTE DE VIGOR) AOS 4 DIAS APÓS A SEMEADURA. LABORATÓRIO de anÁlise de sementes. Departamento de Produção Vegetal. Escola Superior de Agricultura “Luiz DE QUeIroZ”. UniversidAde de SÃo PAUlo. 2013

Figura 4 - VALORES MÉdIOS (LOSANGOS), MíNIMOS, PRIMEIRO QUARTIL, MEDIANOS, TERCEIRO QUARTIL E MÁXIMOS REFERENTES AO COMPRIMENTO DE PARTE AÉREA $\left(\mathrm{C}_{\mathrm{A}}, \mathrm{CM}\right)$ E DE RAIZ $\left(\mathrm{C}_{\mathrm{R}}, \mathrm{CM}\right)$ DE PLÂNTULA DE SOJA AOS 4 dias APÓS A SEMEADURA. LABORATÓRIO DE ANÁlise DE SEMENTES. Departamento de Produção Vegetal. Escola Superior de Agricultura "Luiz de QUEIROZ”. UNIVERSIDADE DE SÃo PAULO. 2013.

FiguRA 5 - VALORES REFERENTES À MASSA DE MATÉRIA SECA DE PARTE AÉREA $\left(\mathrm{M}_{\mathrm{A}}, \mathrm{G}\right)$ E DE RAIZ $\left(\mathrm{M}_{\mathrm{R}}, \mathrm{G}\right)$ DE 10 PLÂNTULAS DE SOJA, AOS 4 diAS APÓS A SEMEADURA. LABORATÓRIO DE ANÁLISE DE SEMENTES. Departamento de Produção Vegetal. Escola Superior de Agricultura "Luiz de QUEIROZ”. UNIVERSIDADE DE SÃo PAULO. 2013

FIGURA 6 - VALORES REFERENTES À RELAÇ̃̃o MASSA DE MATÉRIA SECA DE RAIZ E PARTE AÉREA (R RA, G.G $\left.^{-1}\right)$ DE PLÂNTULAS DE SOJA AOS 4 dias APÓS A SEMEAdURA. LABORATÓRIO DE ANÁLISE DE SEMENTES. Departamento de Produção Vegetal. Escola Superior de Agricultura "Luiz de QUEIROZ”. UNIVERSIDADE DE SÃo PAULO. 2013.

FIGURA 7 - RESULTADOS: VALORES MÉDIOS (LOSANGOS), MÍNIMOS, PRIMEIRO QUARTIL, MEDIANOS, TERCEIRO QUARTIL E MÁXIMOS REFERENTES À GERMINAÇÃO ( $\mathrm{T}_{\mathrm{F}}, \%$ ), APÓS O TESTE DE FRIO (TESTE DE VIGOR), DE PLÂNTULAS DE SOJA AOS 4 DIAS APÓS A SEMEAdURA. LABORATÓRIO DE ANÁliSE DE SEMENTES. Departamento de Produção Vegetal. Escola Superior de Agricultura "Luiz de QUEIROZ”. UNIVERSIDADE DE SÃo PAULO. 2013.

FIGURA 8 - RESULTADOS: VALORES MÉDIOS (LOSANGOS), MÍNIMOS, PRIMEIRO QUARTIL, MEDIANOS, TERCEIRO QUARTIL E MÁXIMOS REFERENTES À ANÁLISE DE IMAGEM (SU - ÍNDICE DE VIGOR) AOS 3 DIAS APÓS A

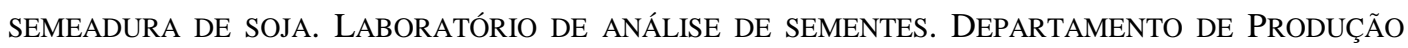




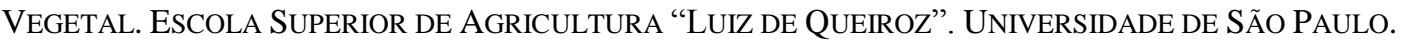
2013

FIGURA 9 - RESUlTAdOS: VALORES MÉDIOS (LOSANGOS), MÍNIMOS, PRIMEIRO QUARTIL, MEDIANOS, TERCEIRO QUARTIL E MÁXIMOS REFERENTES À ANÁLISE DE IMAGEM (SU - ÍNDICE DE CRESCIMENTO) AOS 3 DIAS APÓS A SEMEADURA DE SOJA. LABORATÓRIO DE ANÁLISE DE SEMENTES. DEPARTAMENTO DE Produção Vegetal. Escola SuPERIOR de AGricultura “Luiz de QUEIROZ”. Universidade dE SÃO PAULO. 2013

Figura 10 - REsultados: VAlOREs MÉdios (losAngOS), MÍNIMOS, PRIMEIRO QUARTIL, MEDIANOS, TERCEIRO QUARTIL E MÁXIMOS REFERENTES À ANÁLISE DE IMAGEM (SU - ÍNDICE DE UNIFORMIDADE) AOS 3 DIAS APÓS A SEMEADURA DE SOJA. LABORATÓRIO DE ANÁLISE DE SEMENTES. DEPARTAMENTO DE Produção Vegetal. Escola SuPERIOR de Agricultura “LuIZ DE QueIRoz”. Universidade DE SÃO PAULO. 2013

FIGURA 11 - VALORES MÉDIOS (LOSANGOS), MÍNIMOS, PRIMEIRO QUARTIL, MEDIANOS, TERCEIRO QUARTIL E MÁXIMOS REFERENTES AO VALOR SPAD (SPAD) AOS 13 DIAS APÓS A SEMEADURA DE SOJA. LABORATÓRIO DE ANÁlise DE SEMENTES. DEPARTAMENTO DE PRODUÇÃo Vegetal. Escola SUPERIOR DE AGRICUlturA “LUIZ DE QUEIROZ”. UNIVERSIDAdE DE SÃo PAUlo. 2013.

FIGURA 12 - VALORES MÉDIOS (LOSANGOS), MÍNIMOS, PRIMEIRO QUARTIL, MEDIANOS, TERCEIRO QUARTIL E MÁXIMOS REFERENTES AO TEOR DE PROTEÍNA ( $\left.\mathrm{T}_{\mathrm{P}}, \mathrm{MG}_{\mathrm{ML}}{ }^{-1}\right)$ AOS 11 DIAS APÓS A SEMEADURA DE

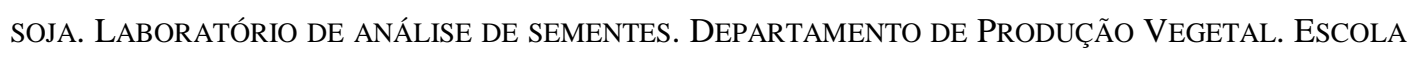
SUPERIOR DE AGRICULTURA “LUIZ DE QUEIROZ”. UNIVERSIDADE DE SÃo PAULO. 2013

FIGURA 13 - VALORES MÉDIOS (LOSANGOS), MÍNIMOS, PRIMEIRO QUARTIL, MEDIANOS, TERCEIRO QUARTIL E MÁXIMOS REFERENTES À FOTOSSÍNTESE (FL, $\mu$ MOL.M $\mathrm{M}^{-2} \cdot \mathrm{S}^{-1}$ ) AOS 15 DIAS APÓS A SEMEADURA DE SOJA. Laboratório de anÁlise de SEMENTES. DePartamento de ProduÇão Vegetal. Escola SuPERIOR DE AGRICULTURA “LUIZ DE QUEIROZ”. UNIVERSIDADE DE SÃo PAULO. 2013

FIGURA 14 - VALORES MÉdIOS (LOSANGOS), MÍNIMOS, PRIMEIRO QUARTIL, MEDIANOS, TERCEIRO QUARTIL E MÁXIMOS REFERENTES À CONDUTÂNCIA ESTOMÁTICA (CE, $\left.\mu \mathrm{MOL} \cdot \mathrm{M}^{-2} \cdot \mathrm{S}^{-1}\right)$ AOS 15 DIAS APÓS A SEMEADURA DE SOJA. LABORATÓRIO DE ANÁliSE DE SEMENTES. DEPARTAMENTO DE PRODUÇÃO

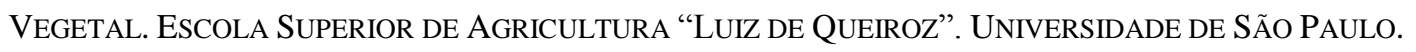
2013

FIGURA 15 - VALORES MÉDIOS (LOSANGOS), MÍNIMOS, PRIMEIRO QUARTIL, MEDIANOS, TERCEIRO QUARTIL E MÁXIMOS REFERENTES À TRANSPIRAÇÃO (TR, MMOL.M ${ }^{-2} \cdot \mathrm{S}^{-1}$ ) AOS 15 DIAS APÓS A SEMEADURA DE SOJA. LABORATÓRIO DE ANÁLISE DE SEMENTES. DEPARTAMENTO DE PRODUÇÃO VEGETAL. EsCOLA SUPERIOR DE AGRICULTURA “LUIZ DE QUEIROZ”. UNIVERSIDADE DE SÃo PAULO. 2013

FIGURA 16 - VALORES MÉDIOS (LOSANGOS), MÍNIMOS, PRIMEIRO QUARTIL, MEDIANOS, TERCEIRO QUARTIL E MÁXIMOS REFERENTES À TEMPERATURA DA FOLHA $\left(\mathrm{TF},{ }^{\circ} \mathrm{C}\right)$ AOS 15 DIAS APÓS A SEMEADURA DE

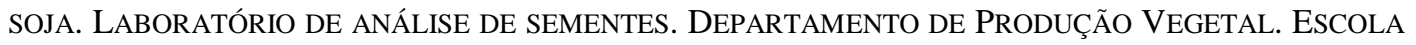
SUPERIOR DE AGRICULTURA “LUIZ DE QUEIROZ”. UNIVERSIDADE DE SÃo PAULO. 2013 
FIGURA 17 - VALORES MÉDIOS (LOSANGOS), MÍNIMOS, PRIMEIRO QUARTIL, MEDIANOS, TERCEIRO QUARTIL E MÁXIMOS REFERENTES AO CONTEÚDO DE PERÓXIDO DE HIDROGÊNIO $\left(\mathrm{H}_{2} \mathrm{O}_{2}\right)\left(\mathrm{P}_{\mathrm{H}}, \mu \mathrm{MOL}\left[\mathrm{H}_{2} \mathrm{O}_{2}\right] \cdot \mathrm{G}^{-1}\right.$ DE MATÉRIA FRESCA) AOS 11 diAS APÓS A SEMEADURA DE SOJA. LABORATÓRIO DE ANÁlISE DE Sementes. Departamento de Produção Vegetal. Escola Superior de Agricultura "Luiz DE QUEIROZ”. UNIVERSIDADE DE SÃo PAULO. 2013.

FIGURA 18 - VALORES MÉDIOS (LOSANGOS), MÍNIMOS, PRIMEIRO QUARTIL, MEDIANOS, TERCEIRO QUARTIL E MÁXIMOS REFERENTES À ATIVIDADE DA ENZIMA CATALASE (CAT, $\mu$ MOL[ $\left.\mathrm{H}_{2} \mathrm{O}_{2}\right]$.MG[PROTEÍNA] ${ }^{1}$.MIN ${ }^{-1}$ ) AOS 11 DIAS APÓS A SEMEADURA DE SOJA. LABORATÓRIO DE ANÁLISE DE SEMENTES. Departamento de Produção Vegetal. Escola Superior de Agricultura "Luiz de QUEIROZ”. UNIVERSIDADE DE SÃo PAULO. 2013.

FIGURA 19 - VALORES MÉDIOS (LOSANGOS), MÍNIMOS, PRIMEIRO QUARTIL, MEDIANOS, TERCEIRO QUARTIL E MÁXIMOS REFERENTES À CONCENTRAÇÃO DE MALONDIALDEÍDO (MDA) (C, MM [MDA] POR G DE MASSA DE MATÉRIA FRESCA) (PEROXIDAÇÃO DE LIPÍDEOS) AOS 11 DIAS APÓS A SEMEADURA DE SOJA. Laboratório de análise de sementes. Departamento de Produção Vegetal. Escola SuPERIOR DE Agricultura “Luiz de QUEIROZ”. UniVERSIDADE DE SÃo PAULO. 2013

Figura 20 - (A) Teste de Germinação e (B) Teste DE Vigor (envelhecimento acelerado). Laboratório de análise de imagem. Departamento de Produção Vegetal. EsalQ, USP. 2013

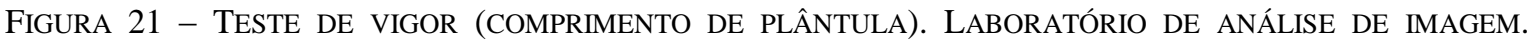
DePartamento de Produção Vegetal. Esalq, USP. 2013.

Figura 22 - RESUltados DA ANÁlise COMPUTADORIZADA DE IMAGENS POR INTERMÉDIO DO SOFTWARE SVIS (SEED VIGOR IMAGE SYSTEM) REFERENTES À PRIMEIRA PARCELA DOS TRATAMENTOS (T): (1) 830 (ÍNDICE DE CRESCIMENTO), 848 (ÍNDICE DE UNIFORMIDADE) E 835 (ÍNDICE DE VIGOR), (2) 833, 864 E 842, (3) 821, 854 E 830, (4) 947, 889 E 929, (5) 911, 894 E 905, (6) 1000, 917 E 975, (7) 818,

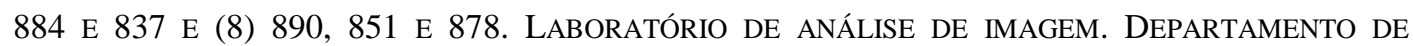
PRODUÇão Vegetal. ESALQ, USP. 2013. 


\section{LISTA DE TABELAS}

TABELA 1 - DesCrição dOS TRATAMENTOS (T), ESPECIFICANDO O NOME TÉCNICO, CONCENTRAÇÃO (C, G.L'

${ }^{1}$ ), E DOSE DO INGREDIENTE ATIVO (D, G.KG ${ }^{-1}$, G DO INGREDIENTE ATIVO POR 100 KG DE SEMENTES) ......42

TABELA 2 - VALORES MÉDIOS REFERENTES À DETERMINAÇÃO DO TEOR DE ÁGUA $\left(\mathrm{T}_{\mathrm{A}}, \%\right)$. LABORATÓRIO DE análise de Sementes. Departamento de Produção Vegetal. Escola Superior de Agricultura “Luiz de QueIroZ”. Universidade De São PaUlo. 2013

TABEla 3 - REsultados: VALORES MÉDIOS REFERENTES AO TESTE DE GERMINAÇão, AOS $4\left(\mathrm{G}_{4}, \%\right)$ E AOS 7 $\left(\mathrm{G}_{7}, \%\right)$ DiaS APÓS A SEMEADURA DE SOJA, E AO COEFICIENTE DE VARIAÇÃO (CV, \%). LabORATÓRIO de anÁlise de sementes. Departamento de Produção Vegetal. Escola Superior de Agricultura “Luiz de QueIroZ”. UniVersidAde De SÃo PAUlo. 2013

TABELA 4 - RESUltados: VALORES MÉDIOS REFERENTES AO ÍNDICE DE VELOCIDADE DE GERMINAÇÃO (IVG, PLÂNTULAS.DIA ${ }^{-1}$ ) DE SOJA E AO COEFICIENTE DE VARIAÇão (CV, \%). LABORATÓRIO DE ANÁLISE DE Sementes. Departamento de Produção Vegetal. Escola Superior de Agricultura "Luiz DE QUEIROZ”. UNIVERSIDADE DE SÃo PAULO. 2013.

TABELA 5 - RESUltAdos: VALORES MÉDIOS REFERENTES À GERMINAÇÃO (EA, \%) DE SEMENTES DE SOJA APÓS

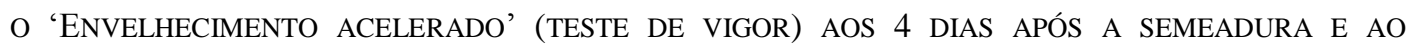
COEFICIENTE DE VARIAÇÃo (CV, \%). LaboratóRIO dE ANÁLISE DE SEMENTES. DEPARTAMENTO dE

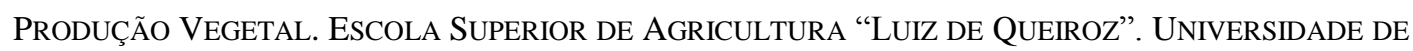
SÃo PAULO. 2013.

TABEla 6 - RESUltados: VALORES MÉdios REFERENTES AO COMPRIMENTO DE PARTE AÉREA $\left(\mathrm{C}_{\mathrm{A}}, \mathrm{CM}\right)$ e DE

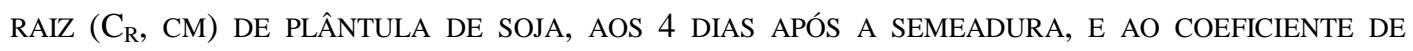
Variação $(\mathrm{CV}, \%)$. Laboratório de análise de sementes. Departamento de Produção Vegetal. Escola SuPERIor de Agricultura “Luiz de QueIroz”. Universidade de São Paulo. 2013

TABEla 7 - REsultados: VALORES REFERENTES À MASSA DE MATÉRIA SECA DE PARTE AÉREA $\left(\mathrm{M}_{\mathrm{A}}, \mathrm{G}\right)$ E DE RAIZ $\left(\mathrm{M}_{\mathrm{R}}, \mathrm{G}\right)$ DE 10 PlÂNTULAS de SOJA, AOS 4 dias APÓS A SEMEAdURA, E AO COEFICIENTE DE Variação $(\mathrm{CV}, \%)$. Laboratório de análise de sementes. Departamento de Produção Vegetal. Escola SuPerior de Agricultura “Luiz de QueIroz”. Universidade de São Paulo. 2013

TABEla 8 - REsultados: VAlORES REFERENTES À RELAÇÃo MASSA DE MATÉRIA SECA DE RAIZ E PARTE AÉREA $\left(\mathrm{R}_{\mathrm{RA}}, \mathrm{G}^{-1} \mathrm{G}^{-1}\right)$ DE PLÂNTULAS DE SOJA AOS 4 DIAS APÓS A SEMEADURA, E AO COEFICIENTE DE Variação $(\mathrm{CV}, \%)$. Laboratório de análise de sementes. Departamento de Produção

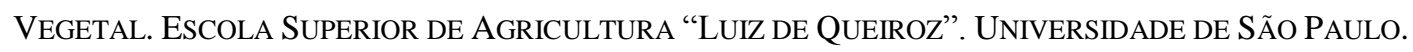
2013

TABela 9 - Resultados: VAlORes MÉdios REFERENTES À GERMinaÇÃo ( $\mathrm{T}_{\mathrm{F}}, \%$ ), APÓS O TESTE DE FRIO (TESTE DE VIGOR), DE PLÂNTULAS DE SOJA AOS 4 DIAS APÓS A SEMEADURA, E AO COEFICIENTE DE 
VARiaçÃo $(\mathrm{CV}, \%)$. LABoratório DE ANÁlise DE SEMENTES. DEPARTAMENTO DE PRODUÇÃo

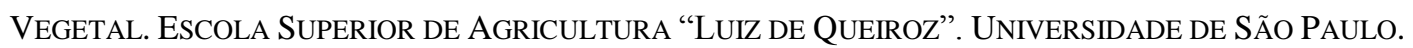
2013 .

TABEla 10 - RESUltAdos: VALORES MÉDIOS REFERENTES À ANÁLISE DE IMAGEM (SV - ÍNDICE DE VIGOR) AOS 3 DIAS APÓS A SEMEADURA DE SOJA E AO COEFICIENTE DE VARIAÇÃO (CV, \%). LABORATÓRIO DE anÁlise de SEMEntes. Departamento de Produção Vegetal. Escola Superior de AGriculturA “LuIZ DE QUEIROZ”. UNIVERSIDADE DE SÃo PAUlo. 2013

TABela 11 - Resultados: VAlORES MÉdios REFERENTES À ANÁlise DE IMAGEM (SC - ÍNDICE DE CRESCIMENTO) AOS 3 DIAS APÓS A SEMEADURA DE SOJA AO COEFICIENTE DE VARIAÇÃO (CV, \%). LABORATÓRIO DE ANÁlise DE SEMENTES. DePartamento de ProduÇão Vegetal. Escola

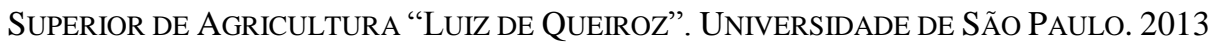

TABela 12 - Resultados: VAlORES MÉdios REFERENTES À ANÁliSE DE IMAGEM (SU - ÍNDICE DE UNIFORMIDADE) AOS 3 DIAS APÓS A SEMEADURA DE SOJA E AO COEFICIENTE DE VARIAÇÃO (CV, \%). LABORATÓRIO DE ANÁlise de SEMENTES. DEPARTAMENTO DE PRODUÇÃo Vegetal. Escola SUPERIOR DE AGRICULTURA “LUIZ DE QUEIROZ”. UNIVERSIDADE DE SÃo PAULO. 2013

TABElA 13 - RESUltAdOS: VALORES MÉDIOS REFERENTES AO VALOR SPAD (SPAD) E TEOR DE CLOROFILA (TC, MG.L ${ }^{-1}$ ), AOS 13 DIAS APÓS A SEMEADURA DE SOJA, E AO COEFICIENTE DE VARIAÇÃO (CV, \%). Laboratório de ANÁlise de SEMENTES. DePartamento de Produção Vegetal. Escola SuPERIOR DE AGRICULTURA “LUIZ DE QUEIROZ”. UNIVERSIDADE DE SÃo PAULO. 2013

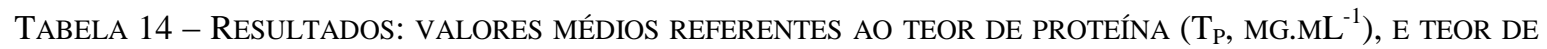
NITROGÊNIO TOTAL $\left(\mathrm{T}_{\mathrm{N}}, \mathrm{MG}_{\mathrm{ML}}{ }^{-1}\right)$ AOS 11 DIAS APÓS A SEMEADURA DE SOJA E AO COEFICIENTE DE VARIAÇÃo $(\mathrm{CV}, \%)$. LABORATÓRIO DE ANÁlise DE SEMENTES. DEPARTAMENTO DE PRODUÇÃO VEGETAl. EsCOlA SUPERIOR DE AGRICUltura “LUIZ DE QUEIROZ”. UNIVERSIDADE DE SÃo PAUlO. 2013

TABElA 15 - RESUltAdOS: VALORES MÉDIOS REFERENTES À FOTOSSÍNTESE (FL, $\mu$ MOL.M ${ }^{-2} \cdot \mathrm{S}^{-1}$ ), AOS 15 DIAS APÓS A SEMEADURA DE SOJA, E AO COEFICIENTE DE VARIAÇÃO (CV, \%). LABORATÓRIO DE ANÁLISE DE SEMEnTes. Departamento de Produção Vegetal. Escola Superior de Agricultura “LUIZ DE QUEIROZ”. UNIVERSIDADE DE SÃo PAULO. 2013.

TABELA 16 - RESUlTADOS: VALORES MÉDIOS REFERENTES À CONDUTÂNCIA ESTOMÁTICA (CE, $\left.\mu \mathrm{MOL} \cdot \mathrm{M}^{-2} \cdot \mathrm{S}^{-1}\right)$, AOS 15 DIAS APÓS A SEMEADURA DE SOJA, E AO COEFICIENTE DE VARIAÇÃO (CV, \%). LABORATÓRIO de anÁlise de Sementes. Departamento de Produção Vegetal. Escola Superior de

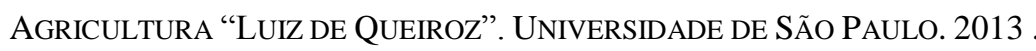

TABELA 17 - RESULTADOS: VALORES MÉDIOS REFERENTES À TRANSPIRAÇÃO (TR, MMOL.M $\left.{ }^{-2} . S^{-1}\right)$, AOS 15 DIAS APÓS A SEMEADURA DE SOJA, E AO COEFICIENTE DE VARIAÇÃO (CV, \%). LABORATÓRIO DE ANÁLISE DE SEMEnTES. DePartamento de Produção Vegetal. Escola Superior de Agricultura “LUIZ DE QUEIROZ”. UNIVERSIDADE DE SÃO PAULO. 2013. 
TABELA 18 - RESUltados: VALORES MÉDIOS REFERENTES À TEMPERATURA DA FOLHA (TF, $\left.{ }^{\circ} \mathrm{C}\right)$, AOS 15 DiAS APÓS A SEMEADURA DE SOJA, E AO COEFICIENTE DE VARIAÇ̃̃o (CV, \%). LABORATÓRIO DE ANÁLISE de sementes. Departamento de Produção Vegetal. Escola Superior de Agricultura “LuIZ DE QUeIROZ”. UniVERSIDADE DE SÃo PAULO. 2013.

TABEla 19 - Resultados: VALORES MÉDios REFERENTES AO CONTEÚdO DE PERÓXIDO DE HIDROGÊNIO $\left(\mathrm{H}_{2} \mathrm{O}_{2}\right)\left(\mathrm{P}_{\mathrm{H}}, \mu \mathrm{MOL}\left[\mathrm{H}_{2} \mathrm{O}_{2}\right] \cdot \mathrm{G}^{-1}\right.$ DE MATÉRIA FRESCA $)$ AOS 11 diAS APÓS A SEMEADURA DE SOJA E AO COEFICIENTE de VARIaÇÃo (CV, \%). LaboratóRIo de anÁlise de SEMENTES. DePaRTAMENTO DE

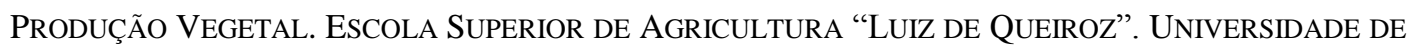
SÃo PAULO. 2013.

TABela 20 - Resultados: valores médios REFERENTES À ATIVIDADE DA ENZiMA CATALASE (CAT, $\mu M O L\left[\mathrm{H}_{2} \mathrm{O}_{2}\right] \cdot M G[\text { PROTEÍNA }]^{-1}$.MIN ${ }^{-1}$ ) AOS 11 DIAS APÓS A SEMEADURA DE SOJA E AO COEFICIENTE DE Variação $(\mathrm{CV}, \%)$. Laboratório de análise de sementes. Departamento de Produção Vegetal. Escola Superior de Agricultura “Luiz de QueIroZ”. Universidade de São Paulo. 2013

TABELA 21 - RESULTADOS: VALORES MÉDIOS REFERENTES À CONCENTRAÇÃO DE MALONDIALDEÍDO (MDA) ( $C$, MM [MDA] POR G DE MASSA DE MATÉRIA FRESCA) (PEROXIDAÇÃo DE LIPÍDEOS) AOS 11 DIAS

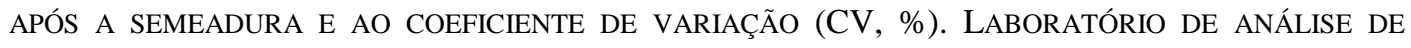
Sementes. Departamento de Produção Vegetal. Escola Superior de Agricultura "Luiz DE QUEIROZ”. UNIVERSIDADE DE SÃo PAULO. 2013. 


\section{INTRODUÇÃO}

A soja é a principal oleaginosa produzida no mundo, sendo a principal fonte de proteína vegetal. Em 2012, o complexo-soja brasileiro gerou divisas de 26,1 bilhões de dólares para o país, segundo relatório da FIESP (2013). Estimativas brasileiras e internacionais apontam que a produção brasileira de soja na safra de 2012/2013 tenha atingido patamares recordes (cerca de 82 milhões de toneladas), colocando-nos como principal produtor desse grão, superando inclusive os Estados Unidos. Os preços pagos mundialmente pela oleaginosa também têm atingido valores considerados elevados, aumentando cada vez mais o interesse econômico pela cultura. Dessa forma, há uma constante busca pelo aumento na lucratividade do sojicultor, por intermédio da redução nos custos de produção, melhoria na logística no país e, sobretudo, pela adoção de práticas de manejo que possibilitem a obtenção de maior produtividade agrícola.

No reino vegetal, aproximadamente $70 \%$ das espécies se reproduzem de forma sexuada, ou seja, das cerca de 350 mil espécies descritas, 250 mil se reproduzem sexuadamente (MARCOS FILHO, 2005). No processo de reprodução sexuada, a semente constitui o início e o fim do ciclo reprodutivo. Sendo assim, a existência das sementes está relacionada à garantia da sobrevivência de grande parte das espécies vegetais. Além de serem as estruturas ligadas à multiplicação das plantas, as sementes constituem, em muitos casos, o material comercializado da espécie vegetal, confirmando assim sua importância econômica.

É também válido ressaltar que as sementes são o veículo de transferência dos avanços tecnológicos obtidos por intermédio das pesquisas em melhoramento genético para o campo. Em contrapartida, são também importantes meios de transporte de patógenos e transmissão de doenças. Seu desempenho, e consequentemente das plantas que delas se originam, está relacionado à sua pureza genética, integridade física, ausência de sementes de outras espécies (invasoras), potencial fisiológico (vigor) e sanidade.

De modo geral, a utilização de sementes de alta qualidade depende da adoção de tecnologia específica durante sua produção e armazenamento, sobretudo em regiões tropicais e subtropicais, como no Brasil. Para assegurar o adequado estabelecimento da lavoura, além da adoção de práticas de manejo ideais para a região, levando-se em consideração época de semeadura, adubação e escolha da variedade cultivada, é preciso contar com uma semente vigorosa e livre de doenças (YORINORI, 1988).

Ainda que assegurada a qualidade da semente de soja, fatores ambientais adversos podem interferir no desenvolvimento das plântulas, sobretudo a presença de pragas e 
patógenos e o suprimento de água no solo. Nessas situações, o tratamento de sementes com fungicidas e inseticidas constitui prática eficaz para assegurar um bom estabelecimento da cultura.

A exemplo de inúmeras espécies vegetais, a soja pode ser afetada por muitas doenças, grande parte transmitida por intermédio das sementes, como Phomopsis sp., Colletotrichum truncatum, Cercospora kikuchii, Cercospora sojina, Fusarium semitectum, Aspergillus sp. e Penicillium sp. Esses patógenos, bem como outros que possam estar presentes no solo, podem ser controlados por intermédio do tratamento de sementes.

O termo tratamento de sementes se refere à aplicação de processos e substâncias às sementes, de modo a preservá-las ou aperfeiçoar seu desempenho, permitindo maior expressão do potencial genético da cultura. Pode envolver não somente produtos fitossanitários, mas também inoculantes, estimulantes, micronutrientes, tratamentos térmicos, físicos, entre outros. Esta prática apresenta como benefícios a menor quantidade de produto a ser utilizado, gerando menor impacto ambiental, além de possibilitar atraso no início de epidemias e aumento na produtividade, assegurando um estande adequado e plantas mais vigorosas. Culturas como a soja e o milho têm praticamente $100 \%$ de suas sementes tratadas com fungicidas, o que representa cerca de 0,5 a $1,0 \%$ do custo de produção total da lavoura (MENTEN; MORAES, 2010).

Neste contexto, o presente trabalho tem por objetivo avaliar o desempenho de diferentes doses e produtos fitossanitários utilizados no tratamento de sementes de soja, procurando caracterizar o efeito fisiológico que possam gerar na germinação e no desenvolvimento das plântulas por intermédio dos testes de germinação e de vigor (índice de velocidade de germinação, envelhecimento acelerado, comprimento e massa de matéria seca de plântula, teste de frio e análise computadorizada de imagem) em laboratório, além da determinação do teor de clorofila (por intermédio do valor SPAD), fotossíntese líquida, condutância estomática, transpiração, temperatura foliar, conteúdo de peróxido de hidrogênio, peroxidação de lipídios, atividade da catalase (enzima antioxidante), e teor de proteína (e de nitrogênio total). 


\section{REVISÃO BIBLIOGRÁFICA}

\subsection{Produção mundial de soja}

A soja é a principal oleaginosa produzida no mundo e também a principal fonte de proteína vegetal. De acordo com o relatório do Foreign Agricultural Service do Departamento de Agricultura dos Estados Unidos, divulgado em novembro de 2013 (USDA, 2013), na safra 2012/2013 foram produzidas mundialmente 267,88 milhões de toneladas de soja, sendo os maiores produtores o Brasil, Estados Unidos e Argentina. Este mesmo relatório aponta como projeções para safra 2013/2014 uma produção global de 283,54 milhões de toneladas, das quais cerca de 88 milhões serão produzidas pelo Brasil e outros 88 pelos Estados Unidos. Ainda tratando-se das informações divulgadas pelo Departamento de Agricultura norteamericano, a produtividade média mundial para a soja na safra 2012/2013 foi de 2,46 toneladas por hectare, enquanto que nos Estados Unidos a média foi de 2,68 t.ha ${ }^{-1}$, na Argentina 2,54 e no Brasil, país com maior produtividade média, 2,96 t.ha ${ }^{-1}$. E as expectativas para a safra 2013/2014 são de aumento da produtividade nos principais países produtores e consequentemente na média mundial, para qual o relatório aponta 2,54 toneladas por hectare.

Tratando-se especificamente do Brasil, a Companhia Nacional de Abastecimento publicou em setembro/2013 o acompanhamento da safra brasileira (CONAB, 2013), no qual a área plantada de soja na última safra (2012/2013) ficou estimada em 27.721 mil hectares, incremento de $10,7 \%$ em relação ao ano anterior, representando um recorde nacional no que diz respeito à oleaginosa. A consequência desse aumento de área, bem como da crescente adoção de novas tecnologias pelo setor rural brasileiro, foi uma produção nacional também recorde, de 81.456,7 milhões de toneladas, aumento de 22,7\% em relação à safra anterior. Além disso, segundo relatório da FIESP (2013), em 2012, o complexo-soja brasileiro gerou divisas de 26,1 bilhões de dólares para o país.

Há mundialmente grande interesse pela cultura doa soja devido à alta qualidade de seus grãos, cuja composição apresenta de 35 a $55 \%$ de proteínas digestíveis, 17 a $27 \%$ de gorduras, $30 \%$ de carboidratos, vitaminas e outros componentes, dependendo da variedade cultivada e das condições de manejo (ALIYEV; MIRZOYEV, 2010).

A produção brasileira de soja destina-se sobretudo ao processamento do grão em óleo e proteína. A proteína processada (torta ou farelo) pode ser utilizada como suplemento protéico na ração animal. Há ainda o consumo na alimentação humana, que vem crescendo a cada ano, tendo em vista que é considerado um alimento funcional, rica em proteínas, além de 
possuir ácidos graxos poli-insaturados e compostos fitoquímicos, tal como as isoflavonas, saponinas e fitatos. Os grãos são também ricos em cobre, ferro, fósforo, potássio, magnésio, manganês e vitaminas do complexo B (RIGON, 2007). Além disso, o óleo de soja figura também como importante matéria prima para o biodiesel.

\subsection{Origem e classificação}

A soja tem como centro de origem a China central e foi domesticada inicialmente nos planaltos do norte chinês, em meados do século 11 d.C., foi introduzida posteriormente na região da Manchúria e Dali espalhou-se pelo oriente (CASTRO; KLUGE; PEPES, 2008).

Essa fabácea (leguminosa) foi introduzida no Brasil em 1882, na Bahia, por Gustavo Dutra, então professor da escola de agronomia da Bahia (VERNETTI, 1983).

Depois disso, o primeiro registro de plantio de soja no Brasil data de 1914, no município de Santa Rosa, RS. Contudo, apenas a partir da década de 40 a sojicultura adquiriu alguma importância econômica, quando houve seu primeiro registro estatístico nacional em 1941, no Anuário Agrícola do Rio Grande do Sul, com uma área cultivada de 640 ha, produção de 450 toneladas e produtividade de $700 \mathrm{~kg}^{-h^{-1}}$. Naquele mesmo ano, instalou-se em Santa Rosa (RS), a primeira indústria processadora de soja do Brasil e, finalmente em 1949, o país apareceu pela primeira vez nas estatísticas internacionais, com uma produção de 25.000 toneladas (EMBRAPA, 2003).

A partir de então, o cultivo da soja expandiu por todo o país, por diversas razões, dentre as quais se pode citar a substituição das gorduras animais (banha e manteiga) por óleos vegetais, mais saudáveis ao consumo humano, às facilidades de mecanização total da cultura, o desenvolvimento de um bem sucedido pacote tecnológico para a produção de soja, com destaque para as novas variedades adaptadas à condição de baixa latitude do centro oeste, a semelhança do ecossistema do sul do Brasil com aquele predominante no sul dos Estados Unidos, favorecendo o êxito na transferência e adoção de variedades e outras tecnologias de produção (EMBRAPA, 2003).

De acordo com a classificação botânica proposta por A. Cronquist, a soja pertence à família Fabaceae, gênereo Glycine, espécie (Glycine max (L.) Merrill). Trata-se de uma espécie de planta $\mathrm{C}_{3}$, que durante o processo de fotossíntese utilizam apenas o ciclo de Calvin-Benson para fixar o $\mathrm{CO}_{2}$, tendo em vista que o primeiro produto da fixação de $\mathrm{CO}_{2}$ é um composto de três carbonos, denominado de 3-fosfoglicerato (ALIYEV, 2010). 
O desenvolvimento e a produtividade da soja são afetados por diversos fatores climáticos, sobretudo pelo fotoperíodo, temperatura e disponibilidade hídrica (EMBRAPA, 2007). A soja é classificada como planta de dias curtos, pois floresce quando as noites são maiores ou os dias menores que um determinado fotoperíodo crítico (CÂMARA; HEIFFIG, 2000, CAMARGO, 2006).

No que diz respeito à temperatura, a soja é influenciada tem todos os seus estádios fenológicos, pois as plantas requerem determinadas quantidades de energia térmica para completar as fases de seu ciclo fenológico (CÂMARA; HEIFFIG, 2000), sendo que seu desenvolvimento é otimizado quando as temperaturas oscilam entre 20 e $30^{\circ} \mathrm{C}$ (EMBRAPA, 2007). Já temperaturas inferiores a $15^{\circ} \mathrm{C}$ tendem a afetar o processo fotossintético e respiratório, a absorção de nutrientes, a translocação e fixação simbiótica do $\mathrm{N}_{2}$ (CÂMARA; HEIFFIG, 2000). Por outro lado, temperaturas superiores a $35^{\circ} \mathrm{C}$ interferem também na fotossíntese e respiração (CÂMARA; HEIFFIG, 2000), na estabilidade de membranas (TAIZ; ZEIGER, 2010), no florescimento e capacidade de retenção das vagens (CAMARGO, 2006).

Em relação à necessidade hídrica da cultura, esta pode variar entre 450 e $800 \mathrm{~mm}$, de acordo com as condições climáticas e técnicas de manejo adotadas, além da duração de seu ciclo (EMBRAPA, 2007).

Alterações na disponibilidade de água durante a fase de germinação e emergência das plântulas podem prejudicar severamente a uniformidade na população de plantas, contudo a deficiência hídrica tende a ser mais prejudicial ao rendimento da cultura quando ocorre no período de florescimento e frutificação (CÂMARA; HEIFFIG, 2000).

Além disso, o excesso de umidade no período da maturação final pode prejudicar o amadurecimento normal dos grãos, aumentando a incidência de patógenos e atrasando a colheita (CÂMARA; HEIFFIG, 2000).

\subsection{Reprodução e desenvolvimento}

A soja reproduz-se de forma sexuada, através da produção de sementes. Possui germinação do tipo epígea, na qual os cotilédones elevam-se acima do nível do solo. Sua semente apresenta raramente problemas relacionados à dormência, sendo mais comum a quiescência, sobretudo quando o suprimento de água no solo não garante a embebição necessária (CASTRO; KLUGE; PEPES, 2008).

A partir da embebição, a semente retoma o metabolismo, através da ativação de sistemas enzimáticos responsáveis pela degradação das reservas existentes. Este processo 
enzimático permite que as reservas sejam transformadas em compostos mais simples e solúveis, translocados via difusão até os pontos de crescimento embrionário (radícula e plúmula), onde contribuem para a formação de novos tecidos que darão origem à plântula (CASTRO; KLUGE; PEPES, 2008).

A garantia da sobrevivência das mais diversas espécies de plantas constitui a razão principal para a existência de sementes. Quando têm como finalidade a multiplicação das espécies vegetais são chamadas de sementes, já do ponto de vista econômico, são a estrutura colhida das plantas, o material de comercialização, denominadas grãos (MARCOS FILHO, 2005).

As sementes possuem papel de destaque nas plantas com reprodução sexuada, constituindo as etapas de início e fim do ciclo de vida destas. É importante ressaltar que aproximadamente de $70 \%$ das espécies de plantas existentes na terra apresentam este tipo de reprodução, ou seja, das cerca de 350 mil espécies descritas, quase 250 mil se reproduzem de forma sexuada (MARCOS FILHO, 2005).

O processo de desenvolvimento de uma plântula de soja pode ser resumido em seis etapas, sendo a primeira a emergência da radícula, seguida da formação de raízes secundárias e elongação do hipocótilo no solo através da formação do gancho plumular. A partir de então a plântula torna-se ereta pela ação da luz nas auxinas e os cotilédones formam o primeiro nó. Neste momento sintetizam clorofila e são capazes de realizar fotossíntese, somando-se à energia já existente nas reservas acumuladas. Posteriormente a planta perde os cotilédones e já é considerada autotrófica (FLOSS, 2011).

O sistema radicular da plântula se torna capaz de absorver nutrientes gradualmente, em paralelo ao desenvolvimento do aparelho fotossintetizante. A planta de soja só se tornará independente das reservas da semente quando for capaz de realizar fotossíntese após receber luz solar e desenvolver tecidos com clorofila (FLOSS, 2011).

O desempenho das sementes (e consequentemente das plantas originadas) está relacionado à sua pureza genética, integridade física, ausência de mistura com plantas invasoras, potencial fisiológico e sanidade (MARCOS FILHO, 2005). Além disso, sementes podem tornar-se eficientes meios de transporte de patógenos e de transmissão de doenças, evidenciando a importância de práticas como a correta armazenagem e o tratamento de sementes, por exemplo.

É importante também atentar à condução e sanidade da planta-mãe, pois o ataque de pragas e doenças, bem como condições inadequadas de temperatura e umidade alteram o 
processo respiratório e oxidação das substâncias de reservas, reduzindo o peso das sementes (MARCOS FILHO, 2005). Um processo de germinação e estabelecimento da cultura bem sucedido está intimamente relacionado à formação e maturação das sementes ainda no campo.

Grande parte dos aspectos negativos das sementes que podem reduzir seu valor comercial tem origem durante sua formação, como danos causados por doenças e pragas, condições ambientais desfavoráveis, entre outros. No caso da soja, por exemplo, sementes enrugadas podem significar que houve deficiência hídrica severa durante o período de transferência de reservas (MARCOS FILHO, 2005).

Existem atualmente inúmeros estudos que objetivam a resolução de problemas referentes ao estabelecimento do estande em campo e manejo das sementes, visando manter seu poder germinativo. Como já mencionado anteriormente, a obtenção de elevada produtividade agrícola tem como princípio básico a utilização de populações de plantas adequadas em uma dada área (plantas.hectare ${ }^{-1}$, por exemplo). Para isso faz-se necessário conhecer com detalhes o processo de germinação e os fatores que podem influenciá-lo, o que pode nortear práticas de manejo do solo, técnicas culturais adequadas, bem como cuidados durante a colheita, processamento, armazenagem e transporte das sementes. Desta forma torna-se possível maximizar a expressão do potencial fisiológico das sementes (MARCOS FILHO, 2005).

\subsection{Vigor e estabelecimento da cultura no campo}

Popinigis (1977) define a qualidade fisiológica de sementes como a capacidade de desempenhar funções vitais, caracterizada pela germinação, vigor e longevidade, afetando diretamente a implantação e estabelecimento da cultura em condições de campo.

Segundo Marcos Filho (2005), o crescimento inicial das plantas é afetado pelo vigor das sementes. O autor afirma que o vigor das sementes determina seu potencial para emergência rápida e uniforme em diferentes ambientes. Sementes com baixo potencial fisiológico podem apresentar características como baixa germinação, alta susceptibilidade a condições de estresse biótico e abiótico, plantas com crescimento lento e irregular e menor desenvolvimento do sistema radicular.

A relação entre vigor de sementes e produtividade final da cultura é bastante discutida e muitos trabalhos apresentam conclusões distintas. Schuch et al. (2000) e Tekrony, Egli e Wickham (1989) afirmaram que o vigor das sementes influencia o crescimento inicial das plântulas mas este efeito tende a diminuir com a evolução do crescimento até a maturação. 
Tekrony e Egli (1991) realizaram um levantamento bibliográfico sobre o tema e relacionaram o vigor e a produtividade de diversas culturas, concluindo que o potencial fisiológico das sementes pode afetar indiretamente a produtividade, por influenciar a velocidade de emergência e a população de plantas. Os autores afirmam que o vigor das sementes afeta o crescimento vegetativo e possui maior influência em culturas colhidas durante o período vegetativo ou início do período reprodutivo. Contudo para culturas colhidas durante a maturidade fisiológica esta correlação não é tão evidente. Dessa forma a utilização de sementes de alto vigor deveria ser justificada para que se assegurem populações de plantas adequadas, mesmo em condições edafoclimáticas adversas que possam ocorrer durante a emergência.

Por outro lado, Schuch, Nedel e Assis (2000) avaliaram o comportamento de plantas isoladas de aveia, observando que as diferenças na produção de matéria seca entre os níveis de vigor foram gradativamente aumentando com o avanço no crescimento das mesmas. Os autores concluíram que este aumento deveria ser atribuído ao desempenho inicial das plântulas de aveia. Dessa forma, supõe-se que sementes de maior vigor originam plantas maiores inicialmente, proporcionando a maximização da exploração do ambiente, o que favorece seu desenvolvimento.

De acordo com Schuch, Kolchinski e Finato (2009), é de grande importância a avaliação dos efeitos do potencial fisiológico das sementes de soja sobre o estabelecimento e desempenho de plântulas em condições de campo, sobretudo dado a sua relevância para o agronegócio e economia brasileira como um todo.

Segundo Fessel et al. (2010) apud Santos et al. (2011), é preciso que o controle de qualidade de sementes seja extremamente eficiente, tendo em vista a competitividade e exigência do mercado. Dessa forma fazem-se necessárias avaliações rápidas que permitam obtenção de informações sobre o potencial fisiológico de sementes, contribuindo para tomadas de decisões nas diferentes etapas do processo de produção, armazenamento e comercialização.

Schuch, Kolchinski e Finato (2009) observaram que plantas de soja oriundas de sementes de diferentes níveis de qualidade fisiológica não diferiram no número de ramificações por planta e no peso de 1000 sementes, contudo as plantas oriundas de sementes de alta qualidade fisiológica apresentam rendimento de grãos $25 \%$ superior às oriundas das sementes de baixa qualidade, além de maior altura e diâmetro de caule. 
Dias et al. (2011) avaliaram os efeitos do vigor de sementes de soja sobre a competição com plantas daninhas e rendimento de grãos e concluíram que sob condições de estresse causadas pela competição com as invasoras, plantas originadas de sementes de baixo vigor obtiveram produtividade consideravelmente menor e a massa de matéria seca das plantas daninhas foi superior àquelas nas quais as sementes de soja utilizadas apresentavam alto vigor.

Vanzolini e Carvalho (2002), avaliando diferentes lotes de soja, concluíram que o maior efeito do vigor de sementes foi no desenvolvimento inicial da cultura, tendo em vista que lotes de menor vigor apresentaram emergência reduzida e em menor velocidade, resultando em menor população de plantas. Os autores observaram também que o vigor interferia na altura das plantas de soja durante a fase vegetativa e que as plantas oriundas de sementes de menor vigor apresentaram prolongamento em sua fase vegetativa. Os autores salientaram também que estas diferenças observadas referem-se apenas aos lotes de baixo vigor, pois para lotes com germinação acima de 75\% não foram observadas diferenças estatisticamente significativas.

Brand et al. (2009) apud Marcos Filho (1999) definiram vigor como o conjunto de atributos que confere à semente a capacidade para germinar, emergir e resultar rapidamente em plântulas normais, sob ampla diversidade de condições ambientais, atributos não demonstrados pelo teste de germinação, evidenciando assim a necessidade de condução de testes de vigor para sementes.

A uniformidade e velocidade de emergência de plântulas são fatores essenciais a um correto estabelecimento do estande das culturas agrícolas, fator fundamental para obtenção de altas produtividades. Dessa forma, o desenvolvimento de métodos de avaliação do potencial fisiológico de sementes tem sido alvo de inúmeras pesquisas (MARCOS FILHO; KIKUTI; LIMA, 2009).

De acordo com Vieira, Bittencourt e Panobianco (2003), a qualidade fisiológica das sementes é comumente avaliada pelo teste de germinação. Contudo, em muitos casos existem divergências entre os resultados obtidos neste teste e na real emergência das plântulas no campo. Desta forma, com objetivo de se obter informações adicionais sobre a qualidade das sementes, foram desenvolvidos inúmeros testes que podem ser conduzidos em um curto período de tempo, como por exemplo, os de envelhecimento acelerado, tetrazólio, teste de frio, condutividade elétrica, deterioração controlada e lixiviação de potássio. 
Segundo Marcos Filho (1999), testes de vigor são úteis em programas de produção de sementes para seleção de lotes, avaliação do potencial de armazenagem, avaliação da deterioração das sementes e para verificar danos mecânicos e térmicos, efeito de tratamentos químicos e condições adversas durante períodos de pré e pós-colheita das sementes.

Vieira, Bittencourt e Panobianco (2003) avaliaram a condução de testes de vigor em empresas de produção de sementes no Brasil e concluíram que são conduzidos rotineiramente em $60 \%$ das instituições privadas e $71 \%$ das públicas, utilizados sobretudo para controle de qualidade e direcionamento das atividades.

Marcos Filho, Kikuti e Lima (2009) descreveram o desenvolvimento e utilização de técnicas de eficiência comprovada no que diz respeito a análise de imagens de plântulas, com o objetivo de correlaciona-las ao vigor das sementes. Neste sentido, os autores salientaram o desenvolvimento do sistema Seed Vigor Imaging System - SVIS ${ }^{\circledR}$. Tomando como base as avaliações de germinação, envelhecimento acelerado (tradicional e com solução saturada de sal), emergência de plântulas e SVIS, os autores concluem que a análise computadorizada de imagens com o uso do SVIS é adequada para a determinação do vigor de sementes de soja e que estes resultados são mais sensíveis no que diz respeito ao crescimento de plântulas.

Santos et al. (2011), conduzindo diferentes testes de avaliação rápida de vigor, emergência de plântulas em campo e análise computadorizada de imagens (SVIS) para diferenciação de lotes de sementes de soja, concluíram que o teste de embebição em água possibilita a classificação quanto ao potencial fisiológico, antes e após o armazenamento, constituindo alternativa promissora para a composição de programas de controle de qualidade.

\subsection{Deterioração de sementes}

De acordo com Jyioti e Malik (2013), a deterioração de uma semente pode ser definida como um conjunto de alterações que ocorrem com o tempo e aumentam a exposição da semente a desafios externos, diminuindo sua habilidade para sobrevivência. Segundo os mesmos autores e Marcos Filho (2005) e Anderson e Baker (1982), trata-se de um processo natural que envolve mudanças citológicas, fisiológicas, bioquímicas e físicas nas sementes, reduzindo gradativamente sua viabilidade até a morte.

Zucareli (2002) apud Delouche (1969) e Delouche; Baskin (1973) descreveram o processo deteriorativo das sementes como uma sequência iniciada pela degradação de membranas celulares, redução das atividades respiratórias e biossintéticas, lentidão do 
processo de germinação, redução no potencial de conservação, decréscimo na taxa de crescimento e de desenvolvimento, menor uniformidade de emergência, maior sensibilidade às adversidades do ambiente, redução da emergência das plântulas no campo, aumento da ocorrência de plântulas anormais e, finalmente, perda da capacidade germinativa.

Anderson e Baker (1983) apontaram que estágios avançados de deterioração podem ser observados através de alta sensibilidade a condições adversas durante o armazenamento, baixa velocidade germinação no campo, baixa emergência, crescimento lento das plântulas e aumento do número de plântulas anormais.

Marcos Filho (2005) listou como manifestações fisiológicas da deterioração a redução da emergência e sua velocidade, declínio da velocidade de crescimento das plântulas, menor resistência a condições desfavoráveis do ambiente ao longo da germinação e crescimento inicial das plântulas, queda no potencial de conservação durante o armazenamento, diminuição da resistência à ação de microrganismos, desuniformidade do desenvolvimento das plantas, maior número de plantas anormais e perda do poder germinativo. Já como manifestações bioquímicas, cita a queda na taxa respiratória e síntese de ATP, além do acréscimo da liberação exsudatos, como etanol e aldeídos voláteis (originados da respiração anaeróbica). $\mathrm{O}$ autor cita também a redução na atividade de inúmeras enzimas, como amilase, $\mathrm{MDH}, \mathrm{ADH}$, esterases, SOD e catalase, além do aumento na peroxidação de lipídios, decréscimo nos teores de açucares, síntese de proteínas entre outras.

Inúmeros trabalhos avaliam a deterioração de sementes em decorrência de condições ocorridas durante sua produção e armazenamento e buscam explorar as causas desta deterioração. Kandil, Sharief e Sheteiwy (2013) avaliaram a qualidade de sementes de soja em função do período, condições e material de armazenagem, conduzindo testes de condutividade elétrica das sementes, percentagem de óleo e de umidade, entre outros e concluíram que para as variedades testadas, as condições que podem maximizar a qualidade das sementes seriam a armazenagem sob condição de refrigeração $\left(10^{\circ} \mathrm{C}+/-1^{\circ} \mathrm{C}\right)$, em sacos de tecido, por até três meses.

Já Tatipata (2009), partindo do princípio de que a deterioração das membranas internas das mitocôndrias é o mecanismo básico do envelhecimento das sementes, estudou o efeito do teor inicial de umidade, período e material de armazenagem sob as membranas mitocondriais de sementes de soja. Segundo o autor, a deterioração das membranas está relacionada a mudanças nos fosfolipídios que a compõe. Em seu trabalho, Tatipata observou a redução do teor de fosfolipídios e proteínas extraídas das mitocôndrias, com o aumento da 
umidade das sementes e tempo de armazenagem, concluindo ter havido desorganização das membranas. O aumento da umidade aumenta a atividade da fosfolipase, ocasionando a hidrólise dos fosfolipídios e consequente desorganização das membranas, aumentando sua permeabilidade. Dessa forma, a respiração mitocondrial e a produção de ATP das células ficariam comprometidas.

Tekrony, Egli e Wickham (1989) avaliaram as alterações ocorridas na respiração mitocondrial nos primeiros estágios de deterioração da semente. Não observam diferenças na germinação, contudo os testes de vigor apresentam alterações com o aumento do tempo de armazenagem, como redução da respiração mitocondrial e aumento da exsudação de solutos. Tekrony e Egli (1991) sugeriram que a queda na respiração mitocondrial estaria associada a mudanças peroxidativas nos lipídios mitocondriais e que essas mudanças já seriam iniciadas antes da perda de vigor das sementes.

\subsection{Tratamento de sementes}

Para muitos pesquisadores, o tratamento de sementes se mostra como uma possibilidade para retardar ou minimizar os efeitos do envelhecimento e deterioração natural das sementes, protegendo-as contra o ataque de doenças e pragas.

A alta produtividade das plantas cultivadas depende da qualidade das sementes e seu desempenho, que está relacionado a seu processo produtivo, processamento e condições edafoclimáticas durante a semeadura e estabelecimento da cultura no campo. $\mathrm{O}$ tratamento de sementes minimiza o uso de produtos fitossanitários, pois, diferente das aplicações foliares e no solo, são aplicados em pequenas quantidades diretamente na semente (MBOFUNG et al., 2013).

Menten e Moraes (2010) definiram tratamento de sementes como a aplicação de processos e substâncias que preservem ou aperfeiçoem seu desempenho, permitindo a total expressão de seu potencial genético. Tais processos podem ser químicos como a aplicação de defensivos agrícolas, micronutrientes, inoculantes, tratamentos térmicos ou de outra natureza física. O tratamento de sementes com produtos fitossanitários tem como objetivo a proteção contra fungos e insetos do solo e patógenos transmitidos pela semente de um modo geral.

Com a expansão da cultura da soja para as regiões Central e Norte do Brasil, tem se tornado mais desafiadora a produção de sementes de alta qualidade, devido à ocorrência de condições climáticas desfavoráveis, como chuvas e altas temperaturas durante as fases de 
maturação e colheita, o que tende a impactar a qualidade fisiológica e a sanidade das sementes (HENNING, 2005; GOULART, 1998).

Inúmeros fungos ocorrem em sementes de soja no Brasil e grande parte das doenças da cultura pode ser transmitida através de sementes (GOULART, 1998), os principais patógenos que podem ser transmitidos via sementes são Phomopsis sp., Colletotrichum truncatum, Cercospora kikuchii, Cercospora sojina, Fusarium semitectum, Aspergillus e Penicillium, Diaporthe phaseolorum var. sojae, Septoria glycines e Diaporthe phaseolorum f. sp.meridionalis e Scleortinia sclerotiorum (HENNING; YUYAMA, 1999; GOULART; PAIVA; ANDRADE, 1995; GOULART, 1998).

Temperatura e umidade elevadas durante a maturação e a colheita das sementes de soja podem favorecer a infecção de fungos, como Phomopsis spp. e Fusarium spp., (FRANÇA NETO; HENNING, 1984). De acordo com Yorinori (1986), a ocorrência de percevejos-sugadores (Euchistus heros, Nezara viridula e Piezodorus güildini) favorece a infecção por Phomopsis spp., Fusarium spp. e Colletotrichum dematium var. truncata. Após a maturação, também há possibilidade de infecções durante os processos de secagem, trilha e armazenamento. Desta forma, torna-se evidente a necessidade do tratamento de sementes de soja com fungicidas, que não somente controlam os fungos veiculados pela própria semente, como também os de solo, que podem prejudicar seriamente o estabelecimento inicial de uma lavoura.

Segundo Henning et al. (2010), o tratamento de sementes com fungicidas (sistêmico + contato) mostra-se como prática necessária e economicamente viável para garantia do estabelecimento da lavoura, sobretudo em condições edafoclimáticas adversas que possam ocorrer após a semeadura da soja. Estima-se que no Brasil de $90 \%$ à totalidade das lavouras de soja façam uso do tratamento de sementes com fungicidas (HENNING et al., 2010; MENTEN; MORAES, 2010).

Wall, Mcgee e Burris (1983) avaliaram os efeitos de tratamentos com fungicidas em sementes de soja com características de qualidade diferente, em condições de solo definidas. Os autores concluíram que alguns dos fungicidas testados foram igualmente eficazes no aumento da emergência em laboratório e campo de lotes de sementes de soja com infeção por Phomopsis spp. acima de 15\%. Em contrapartida, nenhum dos tratamentos foi eficaz em aumentar a emergência em lotes de sementes com danos mecânicos, de tamanho reduzidas ou consideravelmente envelhecidas. Também não foram observadas diferenças em relação a datas de plantio ou tipos de solo. Desta forma os autores concluíram que o tratamento de 
sementes com fungicidas nos solos testados só é justificável em sementes cuja queda na qualidade seja decorrente da infecção por patógenos.

Já Ndimande, Wien e Kueneman (1981) avaliaram se a queda na viabilidade de sementes de soja em solos úmidos é decorrente de fatores fisiológicos ou a microrganismos transmitidos pelas próprias sementes. Os autores aferiram entre outros fatores a aplicação foliar de fungicidas para controle de doenças na planta-mãe, além das condições de armazenamento das sementes após a colheita e sugeriram que os fungos associados às sementes podem desempenhar papel importante em sua qualidade na colheita, mas secundário durante o armazenamento, período durante o qual fatores fisiológicos desencadeados por elevadas temperaturas e umidade seriam o principal agente de deterioração das sementes.

De acordo com Yassen et al. (1994), levando em consideração os trabalhos feitos por Christensen e Kaufman (1969), Christensen (1967, 1972, 1973), e Neergard (1977), sementes infectadas com fungos deterioram mais rápido durante o armazenamento, sendo a principal forma na qual os microrganismos danificam as sementes a produção de enzimas exocelulares e toxinas. Entre as enzimas produzidas, podem ser citadas celulases, pectinases, amilases, lipases, proteases e nucleases e como exemplo de toxinas as aflatoxinas e micotoxinas produzidas por fungos do gênero Aspergillus.

\subsection{Efeitos fisiológicos}

De acordo com Brent e Hollomon (2007), fungicidas têm sido utilizados mundialmente por mais de 200 anos, com o objetivo de proteger plantas contra doenças causadas por fungos. Inicialmente eram usados na proteção de cereais e videiras, mas ao longo dos anos a quantidade de culturas tratadas e a variedade de produtos químicos disponíveis para esta finalidade aumentou significativamente, sobretudo após a segunda guerra mundial.

Esses produtos destinam-se ao manejo de pragas agrícolas, visando a sua morte ou à redução de sua população a níveis que não interfiram na qualidade do produto final das culturas. Contudo, nas duas últimas décadas muitos estudos têm avaliado possíveis efeitos benéficos de diferentes grupos químicos de fungicidas, que vão além da proteção de cultivos, atuando sobre o rendimento das culturas e mecanismos de defesa das plantas hospedeiras (RODRIGUES, 2009). Dentro desta linha de pesquisa, destaca-se o grupo das estrobilurinas, que causariam intensificação na coloração verde (aumento no teor de clorofila) e 
retardamento da senescência, fatos que ocasionariam o aumento da produtividade das culturas no campo, mesmo na ausência de doenças (WEISZ et al., 2011).

De acordo com Bartlett et al. (2002), estudos com aplicações de fungicidas em cerais apontam para maiores produtividades em programas de aplicação baseados em fungicidas do grupo químico das estrobilurinas, quando comparados a aplicações de triazóis, por exemplo, mesmo que ambos apresentem visivelmente o mesmo nível de controle de doenças. Tal fato estaria associado ao chamado "efeito verde" relatado em trabalhos com aplicação de estrobilurinas em diferentes culturas, nos quais são observadas a manutenção de folhas verdes por mais tempo, maximizando o período de enchimento dos grãos e consequentemente aumentando a produtividade. A explicação para estes benefícios além da proteção de cultivos estariam relacionadas a inúmeros fatores fisiológicos.

Weisz et al. (2011), em contrapartida, avaliaram uma série de ensaios de 1994 a 2010 e, levando em consideração série histórica dos preços e ganhos de produtividade obtidos com aplicações de fungicidas, verificaram não haver benefício econômico na aplicação de estrobilurinas ou triazóis na ausência de doenças nos estados de Virginia e Carolina do Norte (Estados Unidos).

Fagan et al. (2010), por intermédio da aplicação foliar da estrobilurina Piraclostrobina em soja, nos estádios fenológicos $R_{1}$ e $R_{5.1}$, observaram que há incremento na taxa fotossintética em ambos os períodos de aplicação. Além disso, os autores relataram ter havido decréscimo na taxa respiratória após a aplicação em $R_{5.1}$. Os resultados indicaram também que houve aumento da atividade da enzima nitrato redutase, quando a aplicação da estrobilurina foi feita no florescimento e não no período de enchimento de grãos. Observou-se ainda aumento na massa de mil grãos e incremento na produtividade em relação ao tratamento sem aplicação e ao tratamento com aplicação de Tebuconazol (Triazol).

Köhle et al. (1997) relataram que os efeitos das estrobilurinas só poderiam ser observados individualmente em condições artificiais, pois na prática são parte de um sistema dinâmico e interativo, no qual cada um dos componentes exerce influência sobre os demais, em maior ou menor intensidade.

Segundo Köhle et al. (2003), experimentos com cereais tratados com Piraclostrobina revelaram aumentos significativos na produção, superando inclusive os ganhos obtidos considerando apenas sua ação fungicida, evidenciando que este ativo apresenta efeitos adicionais na fisiologia da cultura. 
Venâncio et al. (2003) observaram que estes efeitos já haviam sido descritos para outro fungicida do grupo da estrobilurinas, o Kresoxim-mehtyl. As estrobilurinas atuam de forma a inibir a respiração mitocondrial, mediante bloqueio da transferência de elétrons no complexo III (bc1) da cadeia transportadora de elétrons nas mitocôndrias (AMMERMANN et al., 2000; BARTLETT et al., 2002).

Venâncio et al. (2003), levando em consideração que o complexo bc1 está presente em todos os eucariotos, apontaram que deve haver inibição parcial no transporte de elétrons também nas células vegetais após a absorção de fungicidas do grupo das estrobilurinas. Os autores observaram ainda que a Piraclostrobina causaria uma pequena mudança no ponto de compensação de $\mathrm{CO}_{2}$ das plantas e que haveria um aumento transitório na rota alternativa $(\mathrm{AOX})$, superando a redução esperada na emissão de $\mathrm{CO}_{2}$ devido à inibição na respiração mitocondrial.

Diversos trabalhos nos quais se estuda a aplicação de estrobilurinas apontam para um aumento na biomassa. Para isso seria necessária maior assimilação de nitrogênio, o que demonstra haver alguma influência exercida pela Piraclostrobina na atividade da NADHnitrato redutase (VENÂNCIO et al., 2003). Köhle et al. (2003) observaram que a assimilação de nitrato foi superior em plantas tratadas com Piraclostrobina em comparação a plantas sem o tratamento e que nestes casos nem o conteúdo de proteínas ou a relação $\mathrm{C} / \mathrm{N}$ diferiram entre estas plantas, indicando que a maior absorção e redução do nitrato foi utilizada em favor do crescimento das plantas tratadas. Tal fato poderia explicar também o motivo pelo qual muitos trabalhos parecem observar que o maior benefício da aplicação de estrobilurinas ocorra quando a planta apresenta máxima demanda por nitrogênio.

O etileno é considerado como o principal hormônio na senescência das plantas e sua biossíntese pode ser induzida por diversos tipos de lesões, como incidência de doenças, frio ou stress hídrico (TAIZ E ZEIGER, 2010), tendo como enzima chave a ACC-sintetase (VENÂNCIO et al. 2003). Köehle et al. (2003) confirmaram o efeito da aplicação Piraclostrobina em trigo na atividade da ACC-sintetase e na síntese de etileno sob condições de estresse. Neste mesmo trabalho os autores determinaram os níveis hormonais de AIA (ácido indol acético) e ABA (ácido abcísico) e verificaram que a resposta a doses de Piraclostrobina no retardamento da senescência tinha alta correlação com níveis decrescentes da formação de ACC e etileno e aumento do AIA. Dessa forma os autores concluíram que os níveis endógenos de AIA poderiam resultar do metabolismo da Piraclostrobina, pois esta 
(assim como demais moléculas do grupo das estrobilurinas) quebrariam o precursor natural de AIA, L-triptofano, conforme explicações de Köhle et al. (2003) para o trigo.

Além dos tópicos já apresentados, as estrobilurinas parecem também ter ação sob as reações de oxidação de tecidos. Condições ambientais desfavoráveis estimulam a formação de radicais livres, especialmente de espécies reativas de oxigênio (ERO) e aumentam o potencial de oxidação nos tecidos vegetais. Rodrigues (2009) relata que plantas de cevada que apresentavam sintomas elevados de manchas foliares de etiologia desconhecida apresentaram altos níveis de superóxido $\left(\mathrm{O}_{2}^{-}\right)$, peróxidos de hidrogênio $\mathrm{H}_{2} \mathrm{O}_{2}$ e peroxidação de lipídios (malondialdeído, MDA), porém baixo nível de antioxidantes potenciais (superóxido dismutase - SOD). O autor associa a aplicação foliar de estrobilurinas e consequente redução da severidade dos sintomas causados por estas doenças à elevação da atividade da superóxido dismutase (SOD).

Sudisha et al. (2005) avaliaram a aplicação de fungicidas do grupo das estrobilurinas em milheto, via tratamento de sementes e pulverização foliar. Dentre os resultados obtidos, os autores observam que os diferentes princípios ativos testados apresentaram germinação acima de $90 \%$, não diferindo da testemunha e houve aumento estatisticamente significativo no índice de vigor em todos os tratamentos em diferentes doses, com exceção das mais altas (10 e $20 \mu \mathrm{g} \cdot \mathrm{mL}^{-1}$ para Azoxystrobin, $20 \mu \mathrm{g} \cdot \mathrm{mL}^{-1}$ para Trifloxystrobin e para Kresoxim-methyl todas as doses apresentaram melhora no índice de vigor e germinação).

Sudisha et al. (2010) avaliaram os efeitos dos mesmos fungicidas na cultura do girassol e observaram aumento na porcentagem de germinação significativamente diferente para todas as doses de Trifloxystrobin e Kresoxim-methyl. Já em relação ao índice de vigor, todos os tratamentos com os diferentes fungicidas mostraram-se superiores à testemunha.

Mbofung et al. (2013) investigaram o efeito da temperatura de armazenamento e umidade relativa no armazenamento de sementes de soja tratadas quimicamente (fungicidas e fungicidas mais inseticidas) e seus resultados sugerem que as sementes de soja tratadas mantêm maior viabilidade e vigor, independente das condições de armazenamento.

Ainda segundo os autores, citando também Bartlett et al. (2002), o tratamento de sementes normalmente é aplicado para protegê-las de fungos de solo e associados às sementes e insetos-pragas, contudo, alguns tratamentos podem induzir melhoras nas respostas de defesa da planta, em caso de aumento do estresse e melhorar o crescimento e rendimento das plantas. Os mecanismos pelos quais os tratamentos químicos minimizaram as reações de deterioração nas sementes não foram estudados nesse trabalho, no entanto, durante as avaliações 
periódicas da viabilidade das sementes e vigor, os autores observaram que sementes tratadas tiveram menos fungos do que as sementes não tratadas de um modo geral, o que também pode explicar as melhoras nos parâmetros de germinação e vigor.

Outros estudos investigam a relação entre o tratamento químico de sementes e seu vigor, como por exemplo Almeida et al. (2012), que avaliaram a aplicação de Thiamethoxan (inseticida) em sementes de trigo e cevada e concluem que o produto estimula o desempenho fisiológico de trigo e cevada, com intensidade variável de acordo com a variedade cultivada e a dose do produto. Para chegar a esta conclusão, os autores avaliaram parâmetros como germinação, teste de frio, comprimento de raiz e parte aérea e emergência em casa de vegetação.

Benatto et al. (2012) avaliaram o efeito do recobrimento das sementes com polímeros e fungicidas (Carbendazin + Thiram) na qualidade de sementes de soja de alta e baixa germinação. Estes autores concluíram que a aplicação do fungicida mais polímero não afeta negativamente a viabilidade das sementes e promove o vigor daquelas com alta germinação. No teste de envelhecimento acelerado, por exemplo, os tratamentos com fungicida e polímero asseguram a qualidade das sementes, mantendo a germinação acima de $80 \%$.

Brand et al. (2009) investigaram o efeito do tratamento de sementes de soja com um bioprotetor associado ao fungicida Vitavax-Thiram ${ }^{\circledR}$, isoladamente ou combinados, sobre a qualidade sanitária e fisiológica de sementes de soja, pelas avaliações de sanidade, germinação, avaliação de plântulas, emergência em casa de vegetação e no campo. Os resultados obtidos indicam que os tratamentos com fungicidas químicos apresentam a menor incidência de fungos e que a combinação dos produtos com metade da dose proporciona efeito positivo sobre o potencial fisiológico das sementes de soja e que há efeito negativo na correlação entre a incidência de fungos e as variáveis de qualidade fisiológica.

Yan et al. (2010) avaliaram o uso de Uniconazol aplicado em sementes de soja no consórcio de trigo-milho-soja, amplamente utilizado no sudoeste da China, o qual apresenta problemas na produção da oleaginosa, que cresce em condições de sombreamento e apresenta hastes mais finas e é susceptível ao acamamento. Neste trabalho, a altura das mudas, do nó cotiledonar e área foliar por planta foram reduzidos, enquanto que o diâmetro do caule, peso seco da raiz e parte aérea, volume de raiz e coloração verde foram aumentadas em tratamento com Uniconazol, bem como o vigor da raiz e sua área de absorção ativa. Além disso, houve aumento da massa seca, número de vagens por planta, número de sementes por vagem e produtividade de sementes. Desta forma, os autores sugerem que o tratamento de sementes 
com Uniconazol a concentrações adequadas podem melhorar o crescimento de plântulas de soja, sua resistência ao acamamento e também aumentar o rendimento de sementes sob sombreamento pelo milho.

Por outro lado, alguns trabalhos apontam também para algum efeito tóxico da aplicação de produtos químicos (inseticidas ou fungicidas) em sementes, dependendo da dose e do princípio ativo. Castro, Kluge e Pepes (2008) avaliaram o efeito do tratamento de sementes de soja com inseticidas e um bioestimulante na germinação e no crescimento de plântulas e concluem que os tratamentos com os diferentes inseticidas e o bioestimulante levam à formação de raízes mais finas, o que poderia caracterizar efeito tônico, entretanto não foram observados maior crescimento das raízes em nenhum tratamento. Além disso os autores observam que houve efeito fitotóxico da aplicação de Aldicarb, prejudicando o vigor e a germinação das sementes de soja. Dan et al. (2012) também verificaram fitotoxidade de alguns inseticidas aplicados em tratamento das sementes de soja, como Imidaclopride + Tiodicarbe, Acefato e Carbofuram.

\subsection{Grupos químicos utilizados}

\subsubsection{Piraclostrobina - estrobilurinas}

O fungicida Piraclostrobina pertence ao grupo das estrobilurinas, que compreende inúmeras moléculas, tais como Kresoxim-Methyl, Azoxystrobin e Trifloxystrobin. Estas moléculas apresentam como modo de ação em fungos a inibição da transferência de elétrons no sítio Qo no complexo III das mitocôndrias (FRAC, 2013). Estas moléculas foram utilizadas primeiramente na década de 90 e tem sido amplamente aplicadas contra uma ampla variedade de patógenos fúngicos desde então.

\subsubsection{Fluxapiroxade - Carboxamidas}

O Fluxapiroxade é um fungicida pertencente ao grupo químico das carboxamidas, que compreende, entre outras, moléculas como boscalid, bixafen, isopyrazan e sedaxane. Seu modo de ação nos fungos está relacionado à inibição da respiração, inibindo o complexo mitocondrial II (Succinato-deidrogenase). Estes fungicidas são denominados como inibidores SDHI (Succinate dehydrogenase inhibitors), da família química dos pyrazóis-carboximidas (pyrazole- carboxamides) (FRAC, 2013).

O complexo deidrogenase succinato, ou complexo II, utiliza o aceptor de elétrons FAD para efetuar a transferência de elétrons de FADH2 para a Coenzima Q. Através da 
inibição do Complexo II, os fungicidas deste grupo inibem o crescimento do fungo desprovendo suas células de sua fonte de energia e eliminando a disponibilidade de blocos para a síntese de componentes essenciais da célula (ZAMBOLIM; VENÂNCIO; OLIVEIRA, 2007).

Os inibidores do complexo II são fungicidas específicos para basidiomicetos, como a ferrugem asiática, carvões e Rhizoctonia. A especificidade provavelmente reflete a configuração estrutural única do sítio de ação em Basidiomicetos, contudo existem diferenças de eficácia entre as espécies (ZAMBOLIM; VENÂNCIO; OLIVEIRA, 2007).

\subsubsection{Tiofanato metílico - benzimidazóis}

O Tiofanato Metílico é um fungicida pertencente ao grupo químico dos benzimidazóis, ao qual pertencem também o carbendazin e thiabendazol (BRENT; HOLLOMON, 2007). As moléculas pertencentes a este grupo atuam sobre a mitose e divisão celular dos fungos, o Tiofanato Metílico atua especificamente na B-tubulina (FRAC, 2013). Quando o fungicida entra em contato com esta proteína a formação dos microtúbulos é inibida, o que impede que as células se dividam, passando a ser multinucleadas, levando o fungo à morte (BRENT; HOLLOMON, 2007).

\subsubsection{Fipronil - pirazóis}

O Fipronil é um inseticida pertencente ao grupo químico dos pirazóis. Ele atua no sistema nervoso central do inseto inibindo o receptor do ácido gama aminibutírico (GABA). O sistema receptor-GABA, responsável pela inibição da atividade neural anormal, previne o estímulo excessivo dos nervos. Quando a função desse sistema regulador é bloqueada pelo Fipronil ocorre hiperexcitação neural e consequentemente a morte do inseto (COUTINHO et al., 2005). Este ingrediente ativo é comumente utilizado em culturas como batata, cana-deaçúcar, soja, milho, trigo, entre outras, podendo ser aplicado no solo, via tratamento de sementes ou pulverização foliar. 


\section{MATERIAL E MÉTODOS}

\subsection{Locais e período}

Os estudos descritos neste trabalho foram conduzidos, no ano de 2013, nos seguintes locais: (i) Laboratório de Análise de Sementes do Departamento de Produção Vegetal da Escola Superior de Agricultura "Luiz de Queiroz", Universidade de São Paulo (USP/ESALQ), em Piracicaba (SP), (ii) Laboratório de Análise de Imagens do Departamento de Produção Vegetal da Escola Superior de Agricultura “Luiz de Queiroz", Universidade de São Paulo (USP/ESALQ), em Piracicaba (SP), (iii) Laboratório de Genética e Bioquímica de plantas do Departamento de Genética da Escola Superior de Agricultura "Luiz de Queiroz", Universidade de São Paulo (USP/ESALQ), em Piracicaba (SP), (iv) Laboratório de Patologia de Sementes do Departamento de Fitopatologia e Nematologia da Escola Superior de Agricultura "Luiz de Queiroz", Universidade de São Paulo (USP/ESALQ), em Piracicaba (SP), e (v) Estação Experimental Agrícola da BASF S.A., situada no município de Santo Antônio de Posse (SP).

\subsection{Espécie e variedade cultivada}

Foram utilizadas sementes de soja [Glycine max (L.) Merrill], cultivar BMX Potência RR, com germinação considerada adequada para os parâmetros comerciais nacionais (acima de $80 \%$ ) (BRASIL, 2009).

\subsection{Tratamento das sementes}

O tratamento das sementes foi realizado na Estação Experimental Agrícola da BASF S.A., situada no município de Santo Antônio de Posse (SP).

Foram utilizados oito diferentes tratamentos, conforme descrito na Tabela 1. 
Tabela 1 - Descrição dos tratamentos (T), especificando o nome técnico, concentração (C, g.L $L^{-1}$ ), e dose do ingrediente ativo (D, g. $\mathrm{kg}^{-1}, \mathrm{~g}$ do ingrediente ativo por $100 \mathrm{~kg}$ de sementes)

\begin{tabular}{|c|c|c|c|}
\hline $\mathrm{T}$ & Nome técnico & $\mathrm{C}$ & $\mathrm{D}$ \\
\hline 1 & Controle & - & - \\
\hline 2 & Fipronil & 250 & 50 \\
\hline 3 & Fipronil + Piraclostrobina + Tiofanato Metílico & $250+25+225$ & 100 \\
\hline 4 & Fluxapiroxade & 333 & 15 \\
\hline 5 & Fluxapiroxade & 333 & 25 \\
\hline 6 & Fluxapiroxade & 333 & 50 \\
\hline 7 & Fluxapiroxade & 333 & 75 \\
\hline 8 & Piraclostrobina & 500 & 10 \\
\hline
\end{tabular}

\subsection{Teste de sanidade dos lotes}

O teste de sanidade dos lotes de semente foi realizado no Laboratório de Patologia de Sementes do Departamento de Fitopatologia e Nematologia da Escola Superior de Agricultura “Luiz de Queiroz” da Universidade de São Paulo.

Foi realizado por meio do método do papel-filtro com 50 sementes, as quais foram colocadas em placas de Petri, sobre três folhas de papel de filtro e umedecidas com água destilada.

A incubação foi realizada em câmara, à temperatura de $25^{\circ} \mathrm{C}$, em regime de 12 horas de iluminação com lâmpadas fluorescentes, alternados com 12 horas de escuro, durante sete dias.

Após esse período, foram avaliados os fungos presentes nas sementes, com o auxílio de lupa com iluminação e microscópio estereoscópico (HENNING, 1994).

Os resultados obtidos indicaram a incidência de $4 \%$ de Penicillium sp., 5\% de Aspergillus spp. e 2\% de Fusarium pallidoroseum no lote de sementes utilizado.

\subsection{Determinação do teor de água}

O teor de água do lote de sementes foi determinado durante a condução das demais avaliações, pelo método padrão de estufa a $105^{\circ} \mathrm{C}\left(+/-3^{\circ} \mathrm{C}\right)$, por 24 horas (BRASIL, 2009).

Foram realizadas duas repetições para cada lote e os resultados foram expressos em percentagem média, base úmida (Tabela 2). 
Tabela 2 - Valores médios referentes à determinação do teor de água $\left(\mathrm{T}_{\mathrm{A}}, \%\right)$. Laboratório de análise de sementes. Departamento de Produção Vegetal. Escola Superior de Agricultura "Luiz de Queiroz". Universidade de São Paulo. 2013

\begin{tabular}{clr}
\hline $\mathrm{T}$ & Nome técnico $\left(\right.$ Dose $\left.-\mathrm{g}[\mathrm{i} . \mathrm{a}.] .[100 \mathrm{~kg} \text { sementes }]^{-1}\right)$ & $\mathrm{T}_{\mathrm{A}}$ \\
\hline 1 & Controle & 10,83 \\
2 & Fipronil (50) & 10,66 \\
3 & Fipronil + Piraclostrobina + Tiofanato Metílico (100) & 10,49 \\
4 & Fluxapiroxade (15) & 10,64 \\
5 & Fluxapiroxade (25) & 10,11 \\
6 & Fluxapiroxade (50) & 10,56 \\
7 & Fluxapiroxade (75) & 11,10 \\
8 & Piraclostrobina (10) & 11,09 \\
\hline
\end{tabular}

\subsection{Testes de germinação e de vigor}

Os testes de germinação e vigor foram efetuados no intuito avaliar o efeito dos tratamentos de sementes com Fipronil, Fipronil + Piraclostrobina + Tiofanato Metílico, Fluxapiroxade (15, 25, 50 e 75 g por $100 \mathrm{~kg}$ de sementes) e Piraclostrobina no potencial fisiológico das sementes quando comparados com o Controle.

\subsubsection{Teste de germinação}

Os testes foram conduzidos com quatro repetições de 50 sementes por tratamento, em rolos de papel toalha ("germitest"), com quantidade de água equivalente a cerca de 2,5 vezes o peso do papel, mantidos em câmara de germinação a $25^{\circ} \mathrm{C}$ por 7 dias.

As avaliações foram realizadas aos 4 e aos 7 dias após a instalação do mesmo.

A definição de plântulas normais foi verificada conforme as Regras para Análise de Sementes (BRASIL, 2009) e os resultados encontram-se expressos em percentagem de plântulas normais por repetição de cada tratamento.

\subsection{2 Índice de velocidade de germinação}

A determinação do índice de velocidade de germinação (teste de vigor) foi conduzida em caixas plásticas $(47$ x 30 x $11 \mathrm{~cm})$, contendo uma camada de areia de aproximadamente 7 $\mathrm{cm}$.

Foram semeadas 4 repetições de 50 sementes de cada tratamento. Em seguida, as sementes foram cobertas com uma camada de areia de aproximadamente $3 \mathrm{~cm}$ de espessura. 
O umedecimento do substrato foi feito por intermédio do ajuste da disponibilidade de água para $60 \%$ da capacidade máxima de retenção de água contra ação da gravidade (“capacidade de campo").

As caixas foram mantidas em casa de vegetação por 20 dias, para determinação do índice de velocidade de germinação.

Foram realizadas contagens diárias das plântulas normais até a estabilização dos dados. O índice de velocidade de germinação foi calculado de acordo com a fórmula proposta por Maguire (1962):

$$
I V G=\frac{G_{1}}{N_{1}}+\frac{G_{2}}{N_{2}}+\ldots+\frac{G_{n}}{N_{n}}
$$

em que $I V G$ se refere ao índice de velocidade de germinação; $\mathrm{G}_{1}, \mathrm{G}_{2}$, . e e $\mathrm{G}_{\mathrm{n}}$ ao número de plântulas normais na primeira, segunda,... e última (n-ésima) contagem, respectivamente; $\mathrm{N}_{1}$, $\mathrm{N}_{2}, \ldots$ e $\mathrm{N}_{\mathrm{n}}$ ao número de dias transcorridos entre a semeadura e a primeira, segunda,... e última (n-ésima) contagem, respectivamente.

Os resultados foram expressos em índice de velocidade de germinação (plântulas.dia ${ }^{-1}$ ) por repetição de cada tratamento.

\subsubsection{Envelhecimento acelerado}

Para o teste de envelhecimento acelerado (teste de vigor), foram utilizadas quatro repetições de cada tratamento, as quais foram colocadas em caixas de plástico, com dimensões de 11,0 x 11,0 x 3,0 cm, em compartimentos individuais (pequenas câmaras) que possuem em seu interior suportes para apoio de uma tela metálica, na qual foram distribuídas as sementes em camada simples.

Em cada caixa foram adicionados $40 \mathrm{~mL}$ de água, de modo a permitir uma umidade relativa do ar em contato com as sementes de, aproximadamente, $100 \%$.

Essas caixas foram tampadas e mantidas em câmara de envelhecimento do tipo B.O.D., regulada a $41^{\circ} \mathrm{C}$, durante 72 horas.

Após esse período, foi conduzido o teste de germinação conforme procedimento descrito no item 3.4.1 e computada a percentagem média de plântulas normais de soja (MARCOS FILHO; KIKUTI; LIMA, 1999).

\subsubsection{Comprimento e massa de matéria seca de plântula}

Determinou-se a massa de matéria seca da parte aérea e de raízes e o comprimento das plântulas de soja (parte aérea e raízes, separadamente) em laboratório (testes de vigor). 
Os estudos foram conduzidos com 4 repetições de 10 sementes por tratamento, em rolos de papel toalha (germitest), com quantidade de água equivalente a cerca de 2,5 vezes o peso do papel.

As sementes foram dispostas em linhas longitudinais no terço superior do papel, com as extremidades da radícula voltadas para a parte inferior do papel. As avaliações foram realizadas aos 4 dias após a instalação do mesmo, com uma régua graduada em milímetros.

Foi determinado o comprimento da raiz primária e da parte aérea das plântulas consideradas normais. O comprimento médio foi obtido somando-se as medidas de cada plântula normal e dividindo-se pelo número total de sementes avaliadas. Foi calculada a média para plantas normais.

Após aferir o comprimento das plântulas, suas partes foram colocadas separadamente em sacos de papel e mantidas em estufa a $60^{\circ} \mathrm{C}$ para determinação da massa de matéria seca.

Os resultados encontram-se expressos em g por de 10 plântulas.

\subsubsection{Teste de frio}

Para condução do teste de frio (teste de vigor), foram distribuídas quatro repetições de 50 sementes de soja de cada lote, sobre duas folhas de papel toalha Germitest. O conjunto foi coberto com uma terceira folha e enrolado.

As folhas de papel Germitest foram previamente umedecidas com quantidade de água equivalente a 2,5 vezes o seu peso seco.

Os rolos foram mantidos durante sete dias a $10^{\circ} \mathrm{C}$.

Decorridos os respectivos períodos, os rolos foram transferidos para um germinador, a $25^{\circ} \mathrm{C}$, por três dias e, em seguida, foram efetuadas as contagens de plântulas normais.

Os resultados foram expressos em porcentagem (\%) média por lote.

\subsubsection{Análise de imagem}

Para determinação do índice de vigor, foram utilizadas 4 repetições por tratamento, com 25 sementes de soja cada, dispostas em rolos de papel toalha e mantidas em câmara de germinação, conforme descrito no item 3.4.1 por três dias (HOFFMASTER et al., 2003).

Após esse período, as plântulas de cada repetição de cada tratamento foram transferidas para uma folha de cartolina preta de dimensões de 30 x $22 \mathrm{~cm}$ (correspondente à área útil do scanner), sendo colocada sobre a plataforma interna de uma caixa metálica. 
Foram captadas imagens das plântulas em scanner HP Scanjet 2004, instalado de maneira invertida no interior de uma caixa de alumínio de $60 \times 50$ × $12 \mathrm{~cm}$ e operado por software Photosmart, com resolução de 100 dpi.

As imagens escaneadas foram salvas em pasta específica do disco rígido e analisadas pelo software Seed Vigor Imaging System $\left(\right.$ SVIS $\left.^{\circledR}\right)$.

Nessa análise, o eixo raiz-hipocótilo de cada plântula é sinalizado em vermelho. Contudo, quando necessário, correções manuais de possíveis erros são feitas mediante utilização do "mouse".

Após a análise da imagem de cada plântula, o software gera automaticamente valores numéricos referentes ao índice de vigor, índice de crescimento e de uniformidade de desenvolvimento das plântulas.

O valor do índice de vigor é resultante da combinação de índices de crescimento e de uniformidade (valor variável entre 0 e 1000).

\subsection{Valor SPAD e teor de clorofila da folha}

Para determinar o teor de clorofila na folha de plântula de soja foi utilizado um medidor portátil de clorofila (clorofilômetro da marca Minolta, modelo SPAD-502), que permite obter leituras instantâneas do teor de clorofila das folhas, sem que seja necessário destruí-las.

As leituras foram realizadas aos 13 dias após semeadura, em três plântulas por repetição, dispostas em caixas de areia, conforme descrito no item 3.4.2.

Posteriormente foi utilizada a equação proposta por Moran e Porath (1980) e Moran (1982), para determinação do teor de clorofila (TC, mg.L $\left.\mathrm{L}^{-1}\right)$ :

$$
T C=a+b . s
$$

em que a e b se referem aos parâmetros da equação $\left(a=-1,4693 \mathrm{mg} \cdot \mathrm{L}^{-1} ; \mathrm{b}=0,3975\right.$ mg. $\mathrm{L}^{-1}$.SPAD ${ }^{-1}$ ); e s ao valor SPAD (SPAD) observado.

Dessa forma, o teor de clorofila foi comparado aos valores do SPAD-502, obtendo-se uma equação linear. Assim, as medidas do teor de clorofila podem ser determinadas utilizando-se uma curva (linear) de calibração (LIMA FILHO; MALAVOLTA; CABRAL, 1997; FAGAN, 2007). 


\subsection{Proteína e nitrogênio total}

Para extração das proteínas, as amostras foram maceradas até formar uma farinha. Posteriormente, foi adicionado o tampão de extração.

Os materiais foram homogeneizados no tampão de extração na proporção de $1 \mathrm{~g}$ de amostra por $4 \mathrm{~mL}$ de tampão e em seguida o homogeneizado foi centrifugado a $10.000 \mathrm{rpm}$ por 30 minutos a $4^{\circ} \mathrm{C}$.

O sobrenadante foi coletado e dividido em alíquotas para serem estocadas em freezer $80^{\circ} \mathrm{C}$ até o momento da análise (GOMES JÚNIOR et al., 2007).

A concentração das proteínas totais foi determinada segundo o método de Bradford (1976), utilizando-se o BSA (Bovine Serum Albumin) como padrão, por espectrofotometria (Beckman, modelo J2-MC) a $595 \mathrm{~nm}$.

\subsection{Trocas gasosas e temperatura foliar}

A fotossíntese líquida, condutância estomática, transpiração e temperatura foliar foram determinadas aos 15 dias após a semeadura, em quatro repetições por tratamento, duas plantas por repetição, sendo essas plantas dispostas em caixas de areia, conforme descrito no item 3.4.2.

Foi utilizado um sistema portátil de medição de trocas gasosas, IRGA (Infra Red Gas Analyzer), modelo LI-6400 (LI-COR).

As medições de fotossíntese líquida, condutância estomática e transpiração foliar foram realizadas das 9:00 h às 11:00 h da manhã.

Cada folha utilizada para medição foi colocada dentro da câmara selada do equipamento, não suprida por ar externo, sendo estabelecidos $800 \mu \mathrm{mol} . \mathrm{m}^{-2} . \mathrm{s}^{-1}$ da radiação fotossinteticamente ativa.

Essa intensidade de radiação foi escolhida devido à aclimatação das plantas ao local de menor incidência de radiação solar (casa de vegetação), quando comparada ao campo, onde se utiliza o valor de $1.000 \mu \mathrm{mol} . \mathrm{m}^{-2} . \mathrm{s}^{-1}$ da densidade de fluxo de fótons fotossintetizantes.

A mudança de concentração de $\mathrm{CO}_{2}$ por unidade de tempo possibilitou a estimativa da fotossíntese líquida (assimilação de $\mathrm{CO}_{2}$ ), conforme equações matemáticas já pré-definidas no equipamento. 


\subsection{Peróxido de hidrogênio}

$\mathrm{O}$ conteúdo de peróxido de hidrogênio $\left(\mathrm{H}_{2} \mathrm{O}_{2}\right)$ foi determinado por intermédio da reação com iodeto de potássio (KI), segundo Alexieva et al. (2001).

As amostras (massa de matéria fresca) foram maceradas com $1 \mathrm{~mL}$ de TCA (ácido tricloroacético) a $0,1 \%$.

Após completa homogeneização, as amostras foram transferidas para tubos e centrifugadas a $9.700 \mathrm{rpm}$ por 15 minutos a $4^{\circ} \mathrm{C}$.

Do sobrenadante, foram retirados $200 \mu \mathrm{L}$, aos quais foram adicionados $200 \mu \mathrm{L}$ de tampão fosfato de potássio $100 \mathrm{mM}$ (pH 7,0) e $800 \mu \mathrm{L}$ de solução de KI (1 M).

O branco consistiu na mesma mistura descrita acima, porém, ao invés do sobrenadante da amostra, colocou-se $200 \mu \mathrm{L}$ de TCA a $0,1 \%$.

Os tubos com a reação foram colocados em banho de gelo e permaneceram no escuro durante uma hora.

A leitura foi realizada em espectrofotômetro (Lambda 40, Perkin Elmer) a $390 \mathrm{~nm}$.

$\mathrm{O}$ conteúdo de peróxido de hidrogênio $\left(\mathrm{H}_{2} \mathrm{O}_{2}\right)$ foi expresso em $\mu$ mol.g ${ }^{-1}$ de matéria fresca utilizando curva de calibração com concentrações conhecidas de peróxido de hidrogênio.

\subsection{Catalase}

A atividade da catalase foi determinada por espectrofotometria, conforme descrito por Kraus, Mckersie e Fletcher (1995), com algumas modificações efetuadas por Azevedo et al. (1998).

Em temperatura de $25^{\circ} \mathrm{C}$, a atividade foi determinada em uma solução de reação formada por $1 \mathrm{~mL}$ de tampão fosfato de potássio $100 \mathrm{mM}(\mathrm{pH}$ 7,5) e 0,025 $\mathrm{mL}$ de peróxido de hidrogênio (25\%), a qual deve ser preparada no momento do ensaio.

A reação foi iniciada com $25 \mu \mathrm{L}$ de extrato protéico, sendo a atividade determinada através da decomposição de peróxido de hidrogênio, monitorada por 1 minuto por intermédio de alterações na absorbância a $240 \mathrm{~nm}$.

Os resultados foram expressos em $\mu$ mol de $\mathrm{H}_{2} \mathrm{O}_{2}$ por $\mathrm{mg}$ de proteína por minuto $\left(\mu \mathrm{mol}\left[\mathrm{H}_{2} \mathrm{O}_{2}\right] \cdot \mathrm{mg}[\text { proteína }]^{-1} \cdot \min ^{-1}\right)$ para o meio. 


\subsection{Peroxidação lipídica (MDA)}

A peroxidação de lipídeos foi determinada por meio da produção de metabólitos reativos a ácido 2-tiobarbitúrico (TBA), principalmente o malondialdeído (MDA), segundo Heath e Packer (1968).

O material vegetal fresco (300 mg) foi macerado em $5 \mathrm{~mL}$ de TCA (ácido tricloroacético) $\quad 0,1 \%$ (em água) contendo aproximadamente $4 \%$ de PVPP (polivinilpirrolidona) (MIHARA; UCHIYAMA; FUKAZAWA, 1980).

Após homogeneização, as amostras foram transferidas para tubos e centrifugadas a 10.000 g por cinco minutos (MIHARA; UCHIYAMA; FUKAZAWA, 1980).

Em $500 \mu \mathrm{L}$ do sobrenadante, são adicionados $2 \mathrm{~mL}$ de uma solução contendo $20 \%$ de TCA (ácido tricloroacético) (ácido 2-tiobarbitúrico) + 0,5\% de TBA (em água). A mistura é mantida por 30 minutos a $95^{\circ} \mathrm{C}$. Ao ser retirada do aquecimento, as amostras são resfriadas em banho de gelo (MIHARA; UCHIYAMA; FUKAZAWA, 1980).

A mistura foi colocada em banho seco a $95^{\circ} \mathrm{C}$ por 30 minutos e resfriada em gelo em sequência. Com o objetivo de separar resíduos que possam ter permanecido ou ter sido formados durante o aquecimento nas amostras, estas foram centrifugadas a $10000 \mathrm{rpm}$ por 10 minutos (MIHARA; UCHIYAMA; FUKAZAWA, 1980).

As leituras foram realizadas em espectrofotômetro (Perkin Elmer Lambda 40) a 535 e $600 \mathrm{~nm}$. Foram retiradas as bolhas que ser formaram nas cubetas. As determinações das concentrações de MDA (malondialdeído) ( $C, \mathrm{mM}$ [MDA] por g de massa de matéria fresca) foram realizadas de acordo com o coeficiente de extinção da reação $\left(155 \mathrm{mM} . \mathrm{cm}^{-1}\right)$, pela seguinte equação (MIHARA; UCHIYAMA; FUKAZAWA, 1980):

$$
C=\left(A B S_{535}-A B S_{600}\right) .155
$$

em que $A B S_{535}$ e $A B S_{600}$ se referem à absorbância a 535 e 600 nm, respectivamente.

\subsection{Delineamento experimental e análise estatística}

Foi utilizado o delineamento inteiramente casualizado com 8 tratamentos e 4 repetições, totalizando 32 parcelas.

Para realização da estatística de comparação de médias foi adotado o nível de significância de 5\% utilizando o teste de Duncan (SAS INSTITUTE, 2010). 


\section{RESULTADOS E DISCUSSÃO}

\subsection{Teste de germinação}

Na primeira contagem do teste de germinação (ANEXO 1) em laboratório, aos 4 dias após a semeadura, observou-se que o Fipronil apresentou melhor desempenho que a Pirclostrobina (formulação inadequada ao tratamento de sementes) e que todos os tratamentos apresentaram desempenho satisfatórios (acima de 80\%) (BRASIL, 2009) e semelhantes.

As diferenças estatísticas desapareceram aos 7 dias após a semeadura, quando todos os tratamentos apresentaram desempenho semelhante no que diz respeito à germinação.

Na Tabela 3 e Figura 1, podem-se observar os resultados obtidos no teste de germinação aos 4 e 7 dias após a semeadura em laboratório.

Tabela 3 - Resultados: valores médios referentes ao teste de germinação, aos $4\left(\mathrm{G}_{4}, \%\right)$ e aos $7\left(\mathrm{G}_{7}, \%\right)$ dias após a semeadura de soja, e ao coeficiente de variação $(\mathrm{CV}, \%)$. Laboratório de análise de sementes. Departamento de Produção Vegetal. Escola Superior de Agricultura "Luiz de Queiroz". Universidade de São Paulo. 2013

\begin{tabular}{llcccc}
\hline $\mathrm{T}$ & Nome técnico (Dose $-\mathrm{g}\left[\right.$ i.a.].[100kg sementes] ${ }^{-1}$ ) & $\mathrm{G}_{4}$ & $\mathrm{Dc}^{1}$ & $\mathrm{G}_{7}$ & $\mathrm{Dc}$ \\
\hline 1 & Controle & 90,0 & $\mathrm{AB}$ & 96,0 & $\mathrm{~A}$ \\
2 & Fipronil (50) & 96,5 & $\mathrm{~A}$ & 98,5 & $\mathrm{~A}$ \\
3 & Fipronil + Piraclostrobina + Tiofanato Metílico (100) & 90,0 & $\mathrm{AB}$ & 97,5 & $\mathrm{~A}$ \\
4 & Fluxapiroxade (15) & 90,5 & $\mathrm{AB}$ & 94,5 & $\mathrm{~A}$ \\
5 & Fluxapiroxade (25) & 93,5 & $\mathrm{AB}$ & 95,0 & $\mathrm{~A}$ \\
6 & Fluxapiroxade (50) & 95,0 & $\mathrm{AB}$ & 98,0 & $\mathrm{~A}$ \\
7 & Fluxapiroxade (75) & 90,5 & $\mathrm{AB}$ & 96,0 & $\mathrm{~A}$ \\
8 & Piraclostrobina (10) & 89,5 & $\mathrm{~B}$ & 95,0 & $\mathrm{~A}$ \\
\hline CV & & 4,50 & & 3,29 & \\
${ }^{1}$ Médias seguidas pela mesma letra maiúscula não diferem entre si pelo teste de Duncan (Dc) ao nível de \\
significância de 5\%.
\end{tabular}


(a)

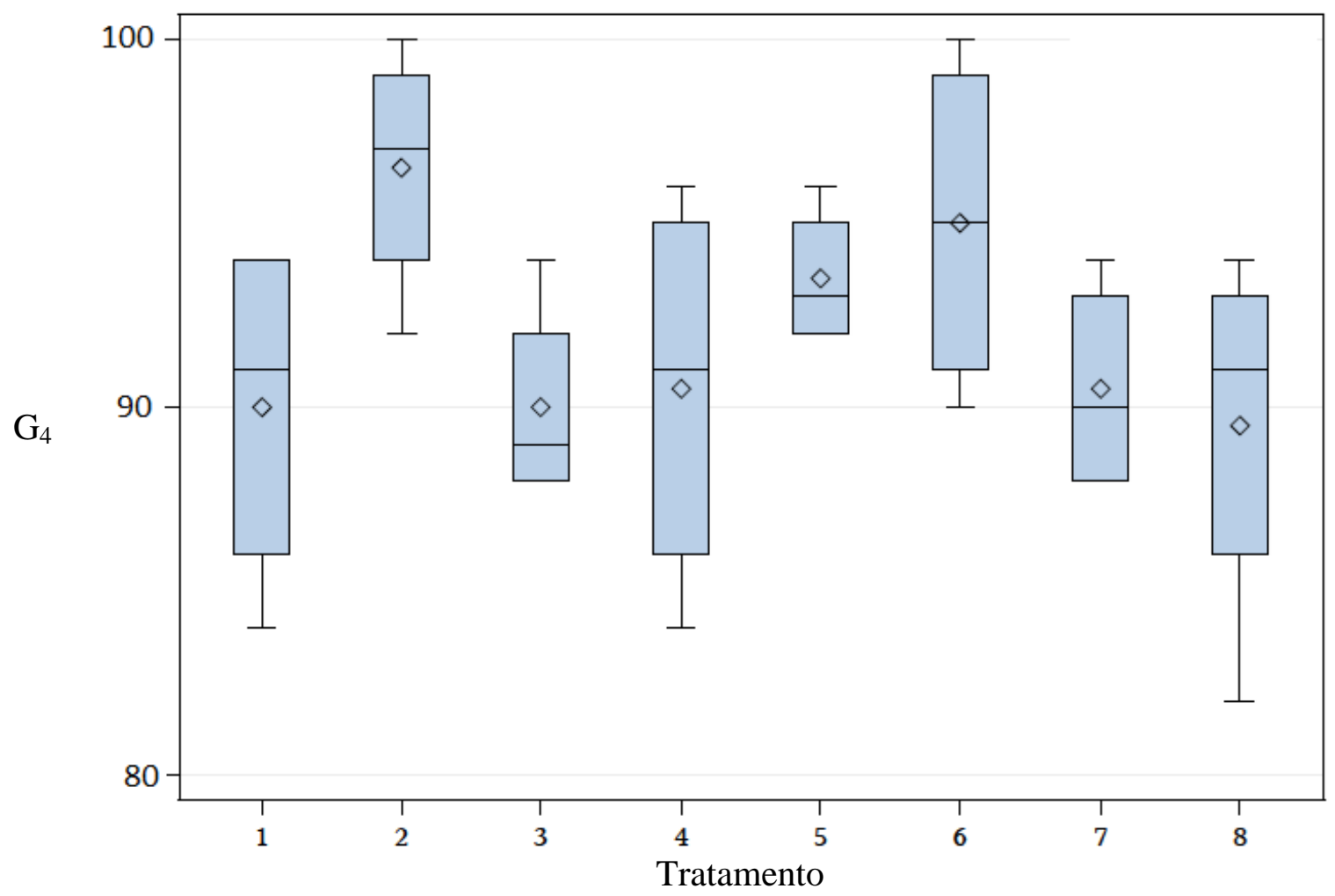

(b)

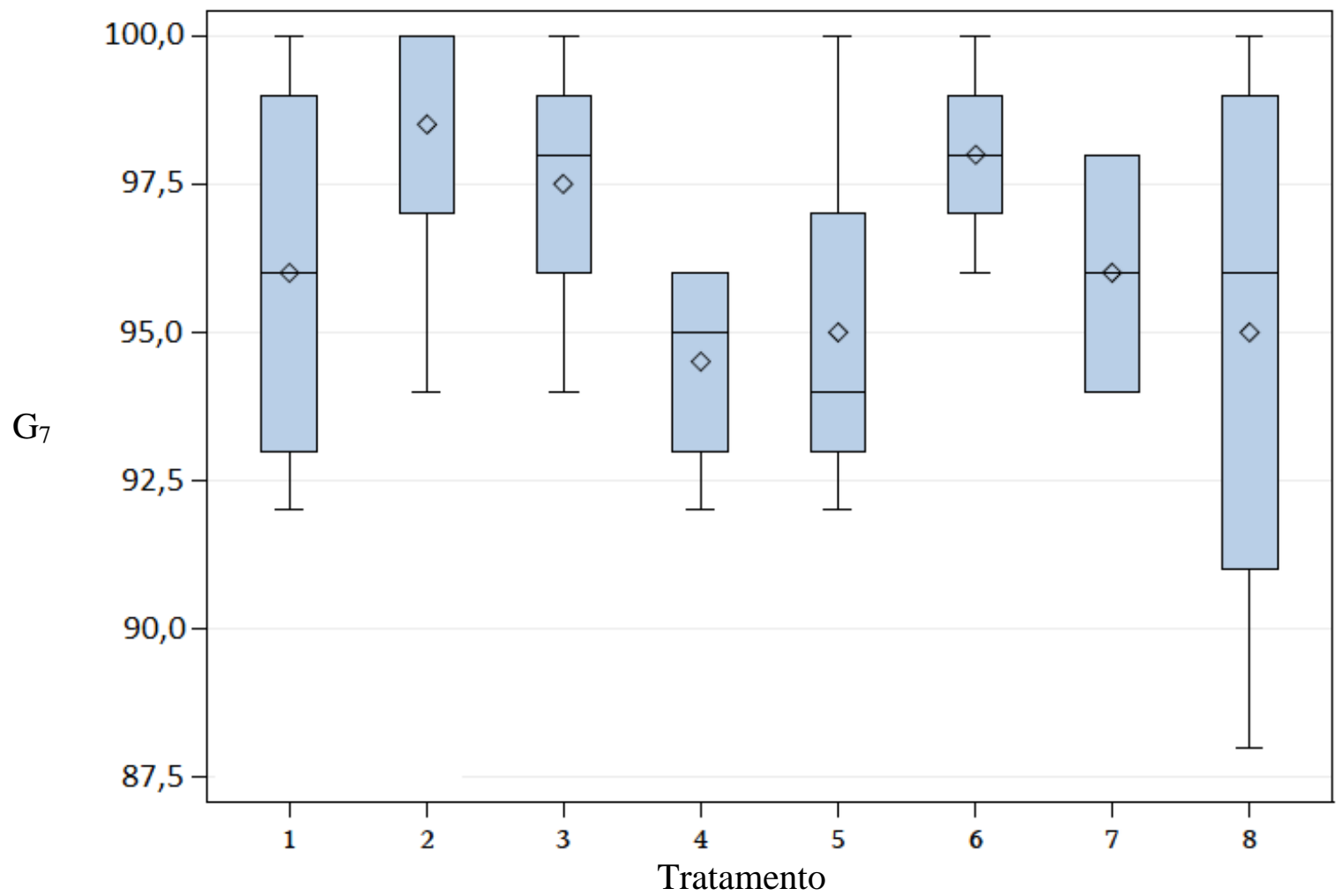

Figura 1 - Valores médios (losangos), mínimos, primeiro quartil, medianos, terceiro quartil e máximos referentes ao teste de germinação, (a) aos $4\left(\mathrm{G}_{4}, \%\right)$ e (b) aos $7\left(\mathrm{G}_{7}, \%\right)$ dias após a semeadura . Laboratório de análise de sementes. Departamento de Produção Vegetal. Escola Superior soja Agricultura "Luiz de Queiroz". Universidade de São Paulo. 2013 


\subsection{Testes de vigor}

\subsection{1 Índice de velocidade de germinação}

Todos os tratamentos apresentaram desempenho semelhantes em termos de índice de velocidade de germinação (IVG, plântulas.dia $\left.{ }^{-1}\right)$, conforme descrição na Tabela 4 e Figura 2. Os tratamentos com Piraclostrobina e Fluxapiroxade apresentaram tendência de melhor desempenho, mas não houve diferença estatística.

Tabela 4 - Resultados: valores médios referentes ao índice de velocidade de germinação (IVG, plântulas.dia $\left.{ }^{-1}\right)$ de soja e ao coeficiente de variação $(\mathrm{CV}, \%)$. Laboratório de análise de sementes. Departamento de Produção Vegetal. Escola Superior de Agricultura "Luiz de Queiroz". Universidade de São Paulo. 2013

\begin{tabular}{llrc}
\hline $\mathrm{T}$ & Nome técnico (Dose $\left.-\mathrm{g}[\mathrm{i} . \mathrm{a}.] .[100 \mathrm{~kg} \text { sementes }]^{-1}\right)$ & $I V G$ & $\mathrm{Dc}^{1}$ \\
\hline 1 & Controle & 14,74 & $\mathrm{~A}$ \\
2 & Fipronil (50) & 14,11 & $\mathrm{~A}$ \\
3 & Fipronil + Piraclostrobina + Tiofanato Metílico (100) & 14,31 & $\mathrm{~A}$ \\
4 & Fluxapiroxade (15) & 14,40 & $\mathrm{~A}$ \\
5 & Fluxapiroxade (25) & 14,96 & $\mathrm{~A}$ \\
6 & Fluxapiroxade (50) & 14,68 & $\mathrm{~A}$ \\
7 & Fluxapiroxade (75) & 16,05 & $\mathrm{~A}$ \\
8 & Piraclostrobina (10) & 15,33 & $\mathrm{~A}$ \\
\hline $\mathrm{CV}$ & & 9,11 &
\end{tabular}

$\begin{array}{ll}\mathrm{CV} & 9,11\end{array}$ ${ }^{1}$ Médias seguidas pela mesma letra maiúscula não diferem entre si pelo teste de Duncan (Dc) ao nível de
significância de $5 \%$. 


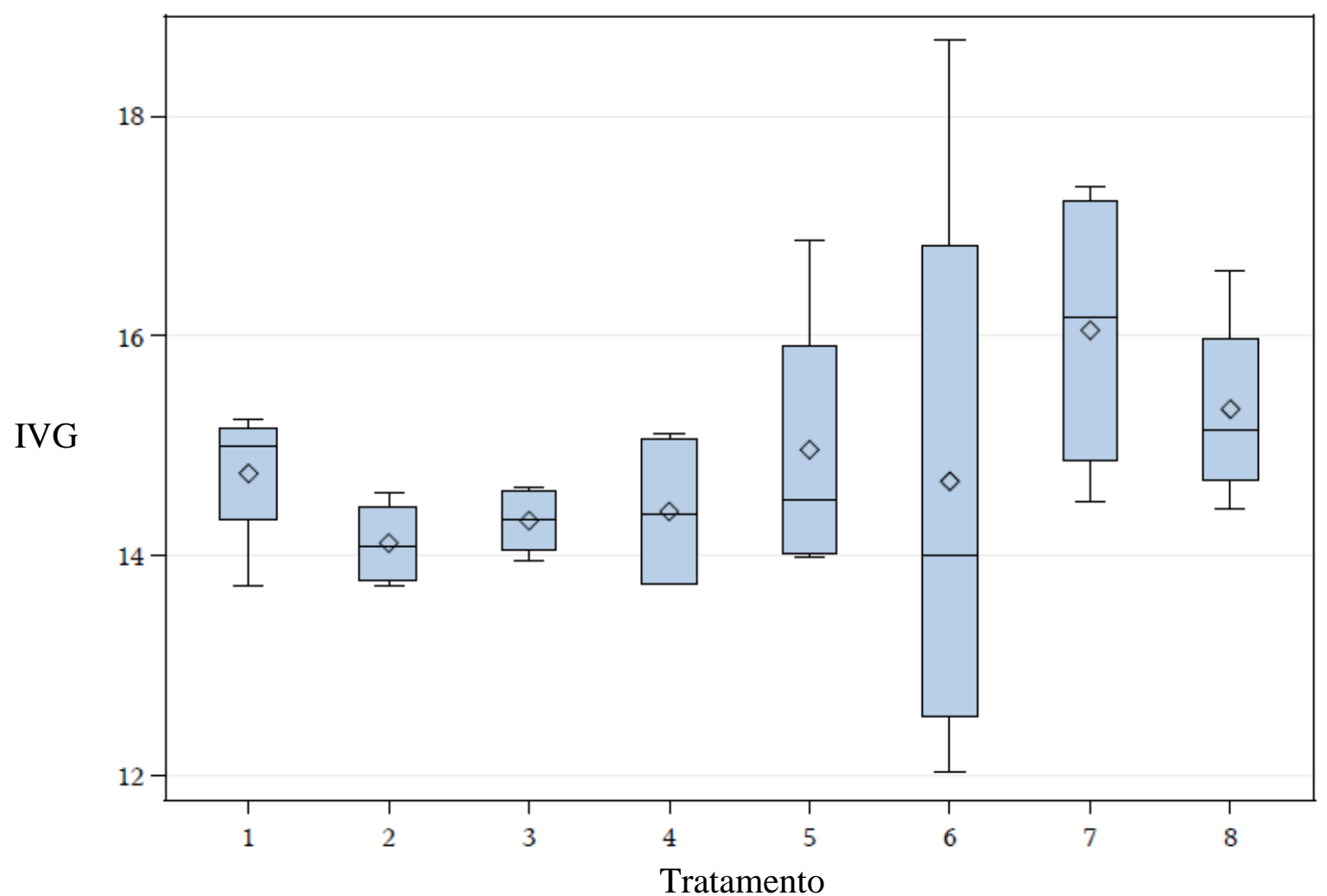

Figura 2 - Valores médios referentes ao índice de velocidade de germinação (IVG, plântulas.dia ${ }^{-1}$ ) de soja. Laboratório de análise de sementes. Departamento de Produção Vegetal. Escola Superior de Agricultura "Luiz de Queiroz". Universidade de São Paulo. 2013

\subsubsection{Envelhecimento acelerado}

O teste de envelhecimento acelerado (ANEXO 1) é comumente utilizado como método de avaliação relativamente rápido e eficiente para determinar o desempenho de sementes das mais variadas espécies (VIEIRA; BITTENCOURT; PANOBIANCO, 2003).

Neste trabalho, o teste de envelhecimento acelerado não apresentou diferenças significativas entre os tratamentos (Tabela 5 e Figura 3), o que indica não haver qualquer tipo de prejuízo ao vigor das sementes quando tratadas com os diferentes produtos químicos descritos. Além disso, a germinação das sementes manteve-se acima de $85 \%$ em todos os tratamentos, mantendo-se dentro dos padrões estabelecidos pelo MAPA (BRASIL, 2009), a exemplo do ocorrido no teste de germinação (item 4.1). 
Tabela 5 - Resultados: valores médios referentes à germinação (Ea, \%) de sementes de soja após o 'Envelhecimento acelerado' (teste de vigor) aos 4 dias após a semeadura e ao coeficiente de variação $(\mathrm{CV}, \%)$. Laboratório de análise de sementes. Departamento de Produção Vegetal. Escola Superior de Agricultura "Luiz de Queiroz". Universidade de São Paulo. 2013

\begin{tabular}{clcc}
\hline $\mathrm{T}$ & Nome técnico (Dose - g[i.a.].[100kg sementes] $\left.{ }^{-1}\right)$ & Ea & Dc $^{1}$ \\
\hline 1 & Controle & 92,0 & A \\
2 & Fipronil (50) & 92,0 & A \\
3 & Fipronil + Piraclostrobina + Tiofanato Metílico (100) & 93,0 & A \\
4 & Fluxapiroxade (15) & 88,5 & A \\
5 & Fluxapiroxade (25) & 90,5 & A \\
6 & Fluxapiroxade (50) & 92,0 & A \\
7 & Fluxapiroxade (75) & 86,5 & A \\
8 & Piraclostrobina (10) & 89,5 & A \\
\hline CV & & 4,46 &
\end{tabular}

${ }^{1}$ Médias seguidas pela mesma letra maiúscula não diferem entre si pelo teste de Duncan (Dc) ao nível de significância de $5 \%$.

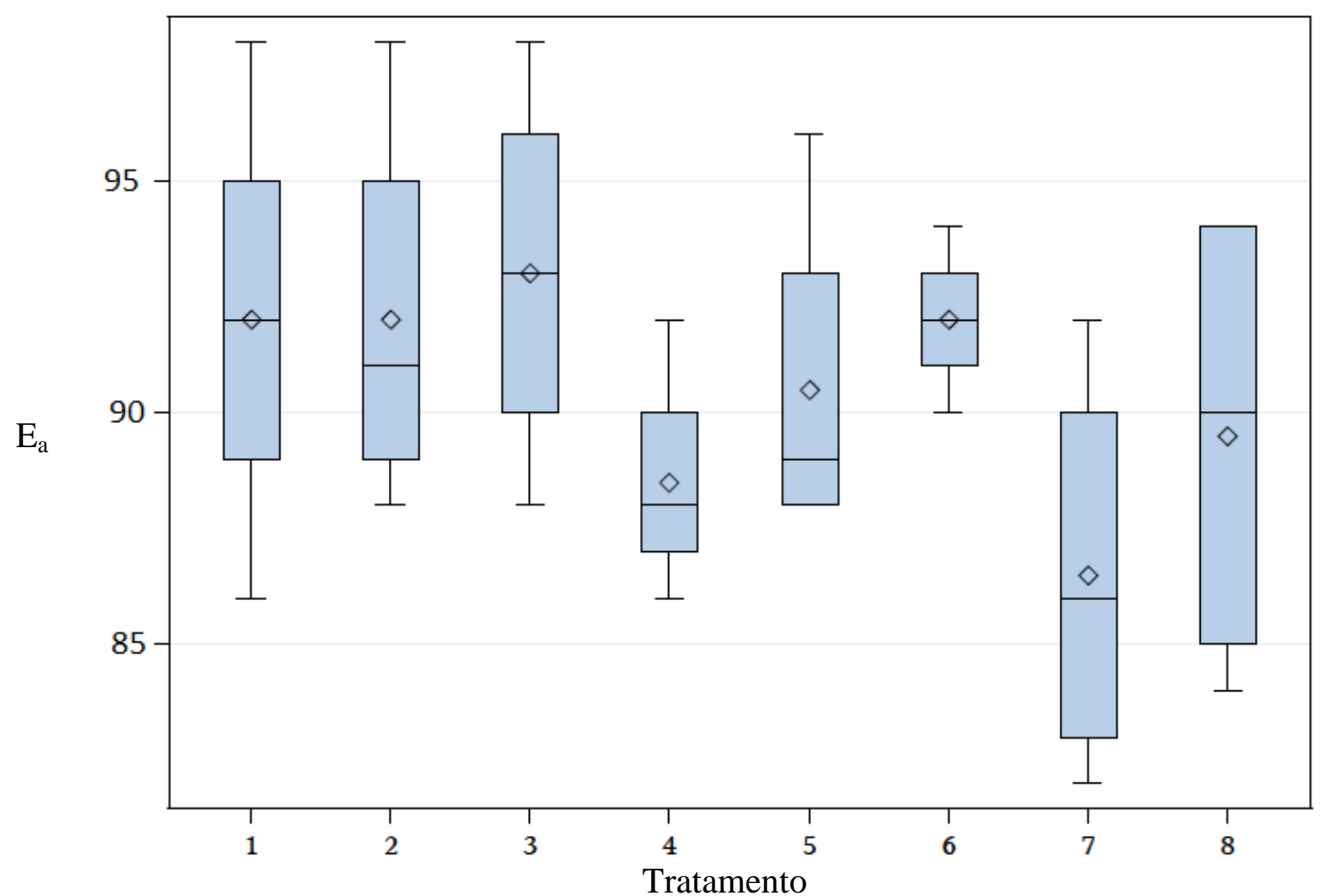

Figura 3 - Resultados: Valores médios (losangos), mínimos, primeiro quartil, medianos, terceiro quartil e máximos referentes à germinação $(E a, \%)$ de sementes de soja após o 'Envelhecimento acelerado' (teste de vigor) aos 4 dias após a semeadura. Laboratório de análise de sementes. Departamento de Produção Vegetal. Escola Superior de Agricultura "Luiz de Queiroz". Universidade de São Paulo. 2013 


\subsubsection{Comprimento de plântula}

Ainda com o objetivo de determinar-se o vigor das sementes, foi aferido o comprimento das plântulas, separado entre parte aérea e raiz, aos 4 dias após semeadura em laboratório (ANEXO 2) (Tabela 6 e Figura 4).

Neste caso observou-se que todos os tratamentos apresentaram desempenho semelhante em termos de comprimento de raiz aos 4 dias após a semeadura e que o tratamento com Fipronil + Piraclostrobina + Tiofanato Metílico apresentou tendência de melhor desempenho, mas não diferiu do Controle e de Fluxapiroxade (25 g por $100 \mathrm{~kg}$ de sementes) em termos de comprimento de parte aérea aos 4 dias após a semeadura;

Tabela 6 - Resultados: valores médios referentes ao comprimento de parte aérea $\left(\mathrm{C}_{\mathrm{A}}, \mathrm{cm}\right)$ e de raiz $\left(\mathrm{C}_{\mathrm{R}}, \mathrm{cm}\right)$ de plântula de soja, aos 4 dias após a semeadura, e ao coeficiente de variação $(\mathrm{CV}, \%)$. Laboratório de análise de sementes. Departamento de Produção Vegetal. Escola Superior de Agricultura "Luiz de Queiroz". Universidade de São Paulo. 2013

\begin{tabular}{llcccc}
\hline $\mathrm{T}$ & Nome técnico (Dose $\left.-\mathrm{g}[\mathrm{i} . \mathrm{a}.] .[100 \mathrm{~kg} \text { sementes] }]^{-1}\right)$ & $\mathrm{C}_{\mathrm{A}}$ & $\mathrm{Dc}^{1}$ & $\mathrm{C}_{\mathrm{R}}$ & $\mathrm{Dc}$ \\
\hline 1 & Controle & 5,0 & $\mathrm{AB}$ & 12,7 & $\mathrm{~A}$ \\
2 & Fipronil (50) & 4,2 & $\mathrm{CD}$ & 10,8 & $\mathrm{~A}$ \\
3 & Fipronil + Piraclostrobina + Tiofanato Metílico (100) & 5,4 & $\mathrm{~A}$ & 12,5 & $\mathrm{~A}$ \\
4 & Fluxapiroxade (15) & 4,1 & $\mathrm{D}$ & 10,8 & $\mathrm{~A}$ \\
5 & Fluxapiroxade (25) & 4,8 & $\mathrm{AB}$ & 12,2 & $\mathrm{~A}$ \\
6 & Fluxapiroxade (50) & 4,5 & $\mathrm{BCD}$ & 11,5 & $\mathrm{~A}$ \\
7 & Fluxapiroxade (75) & 4,7 & $\mathrm{BC}$ & 12,6 & $\mathrm{~A}$ \\
8 & Piraclostrobina (10) & 4,7 & $\mathrm{BCD}$ & 12,5 & $\mathrm{~A}$ \\
\hline $\mathrm{CV}$ & & 7,84 & & 10,05 &
\end{tabular}

${ }^{1}$ Médias seguidas pela mesma letra maiúscula não diferem entre si pelo teste de Duncan (Dc) ao nível de significância de $5 \%$. 
(a)

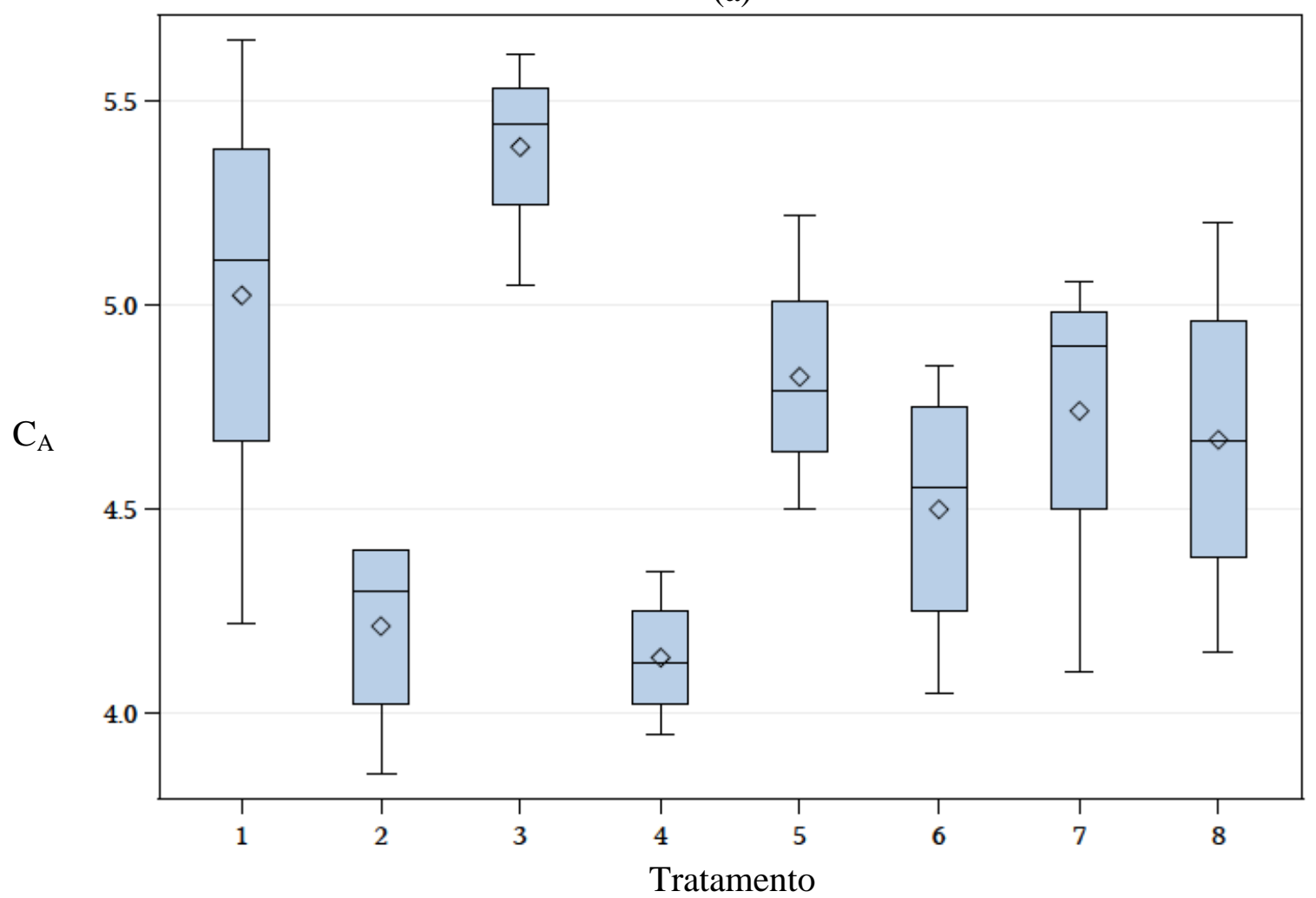

(b)

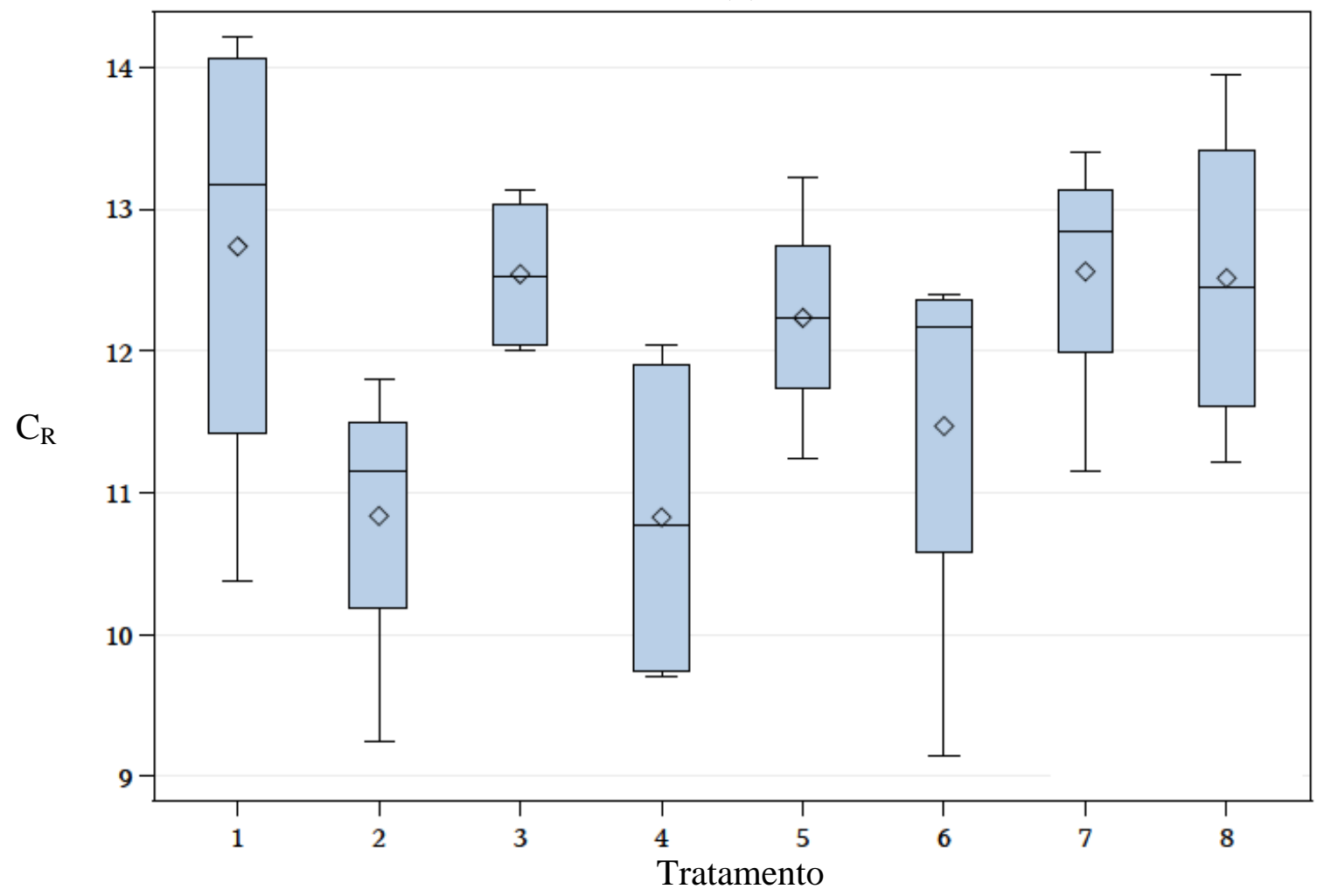

Figura 4 - Valores médios (losangos), mínimos, primeiro quartil, medianos, terceiro quartil e máximos referentes ao comprimento de parte aérea $\left(\mathrm{C}_{\mathrm{A}}, \mathrm{cm}\right)$ e de raiz $\left(\mathrm{C}_{\mathrm{R}}, \mathrm{cm}\right)$ de plântula de soja aos 4 dias após a semeadura. Laboratório de análise de sementes. Departamento de Produção Vegetal. Escola Superior de Agricultura "Luiz de Queiroz". Universidade de São Paulo. 2013 


\subsubsection{Massa de matéria seca de plântula}

Para a massa de matéria seca de plântulas (Tabela 7 e Figura 5), observou-se também que todos os tratamentos apresentaram desempenho semelhante em termos de massa de matéria seca de raiz aos 4 dias após a semeadura. Em relação à parte aérea, entretanto, o tratamento Controle apresentou tendência de melhor desempenho, mas não diferiu dos seguintes tratamentos: Fipronil + Piraclostrobina + Tiofanato Metílico, Fluxapiroxade (25, 50 e $75 \mathrm{~g}$ por $100 \mathrm{~kg}$ de sementes) e Piraclostrobina.

Tabela 7 - Resultados: valores referentes à massa de matéria seca de parte aérea $\left(\mathrm{M}_{\mathrm{A}}, \mathrm{g}\right)$ e de raiz $\left(\mathrm{M}_{\mathrm{R}}, \mathrm{g}\right)$ de 10 plântulas de soja, aos 4 dias após a semeadura, e ao coeficiente de variação (CV, \%). Laboratório de análise de sementes. Departamento de Produção Vegetal. Escola Superior de Agricultura "Luiz de Queiroz”. Universidade de São Paulo. 2013

\begin{tabular}{llcccc}
\hline $\mathrm{T}$ & Nome técnico (Dose $-\mathrm{g}[\mathrm{i} . \mathrm{a}.] .[100 \mathrm{~kg} \text { sementes] }]^{-1}$ ) & $\mathrm{M}_{\mathrm{A}}$ & $\mathrm{Dc}^{1}$ & $\mathrm{M}_{\mathrm{R}}$ & $\mathrm{Dc}$ \\
\hline 1 & Controle & 0,191 & $\mathrm{~A}$ & 0,069 & $\mathrm{~A}$ \\
2 & Fipronil (50) & 0,163 & $\mathrm{BC}$ & 0,072 & $\mathrm{~A}$ \\
3 & Fipronil + Piraclostrobina + Tiofanato Metílico (100) & 0,174 & $\mathrm{ABC}$ & 0,069 & $\mathrm{~A}$ \\
4 & Fluxapiroxade (15) & 0,160 & $\mathrm{C}$ & 0,071 & $\mathrm{~A}$ \\
5 & Fluxapiroxade (25) & 0,167 & $\mathrm{ABC}$ & 0,074 & $\mathrm{~A}$ \\
6 & Fluxapiroxade (50) & 0,175 & $\mathrm{ABC}$ & 0,070 & $\mathrm{~A}$ \\
7 & Fluxapiroxade (75) & 0,185 & $\mathrm{AB}$ & 0,076 & $\mathrm{~A}$ \\
8 & Piraclostrobina (10) & 0,180 & $\mathrm{ABC}$ & 0,072 & $\mathrm{~A}$ \\
\hline $\mathrm{CV}$ & & 8,45 & & 16,20 &
\end{tabular}

${ }^{1}$ Médias seguidas pela mesma letra maiúscula não diferem entre si pelo teste de Duncan (Dc) ao nível de significância de $5 \%$

No que diz respeito à relação observada entre a raiz e a parte aérea das plântulas (Tabela 8 e Figura 6), verifica-se que apenas o tratamento 1 (Controle) mostrou-se inferior, diferindo estatisticamente dos demais. Já os tratamentos Fipronil e Fluxapiroxade (15 e 25 g por $100 \mathrm{~kg}$ de sementes) apresentaram melhor desempenho que o Controle, mas não diferiram dos seguintes tratamentos: Fipronil + Piraclostrobina + Tiofanato Metílico, Fluxapiroxade (50 e $75 \mathrm{~g}$ por $100 \mathrm{~kg}$ de sementes) e Piraclostrobina.

Esses dados podem indicar que as sementes tratadas com os diferentes produtos mostraram-se mais capazes de desenvolver o sistema radicular em comparação com a parte aérea, o que, no campo, poderia indicar que teriam mais condições de se desenvolver em ambientes adversos, como, por exemplo, em situações de estresse hídrico. 
Tabela 8 - Resultados: valores referentes à relação massa de matéria seca de raiz e parte aérea $\left(R_{R A}, g \cdot g^{-1}\right)$ de plântulas de soja aos 4 dias após a semeadura, e ao coeficiente de variação (CV, \%). Laboratório de análise de sementes. Departamento de Produção Vegetal. Escola Superior de Agricultura "Luiz de Queiroz". Universidade de São Paulo. 2013

\begin{tabular}{clcc}
\hline $\mathrm{T}$ & Nome técnico (Dose $-\mathrm{g}[\mathrm{i} . \mathrm{a}] ..\left[100 \mathrm{~kg}\right.$ sementes] $\left.{ }^{-1}\right)$ & $\mathrm{R}_{\mathrm{RA}}$ & $\mathrm{Dc}^{1}$ \\
\hline 1 & Controle & 0,358 & $\mathrm{~B}$ \\
2 & Fipronil (50) & 0,443 & $\mathrm{~A}$ \\
3 & Fipronil + Piraclostrobina + Tiofanato Metílico (100) & 0,395 & $\mathrm{AB}$ \\
4 & Fluxapiroxade (15) & 0,443 & $\mathrm{~A}$ \\
5 & Fluxapiroxade (25) & 0,440 & $\mathrm{~A}$ \\
6 & Fluxapiroxade (50) & 0,400 & $\mathrm{AB}$ \\
7 & Fluxapiroxade (75) & 0,410 & $\mathrm{AB}$ \\
8 & Piraclostrobina (10) & 0,400 & $\mathrm{AB}$ \\
\hline $\mathrm{CV}$ & & 11,89 &
\end{tabular}

${ }^{1}$ Médias seguidas pela mesma letra maiúscula não diferem entre si pelo teste de Duncan (Dc) ao nível de significância de $5 \%$. 
(a)

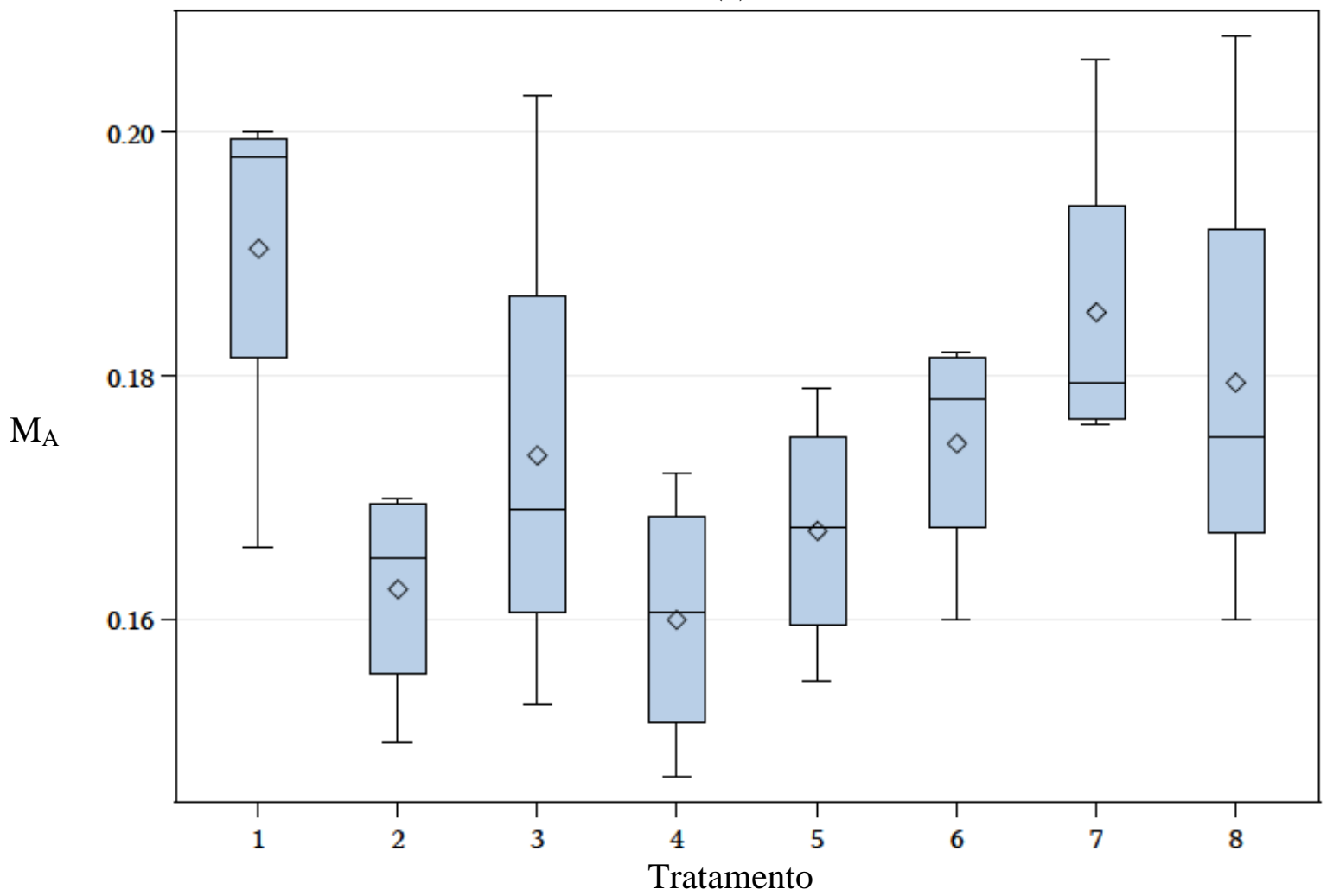

(b)

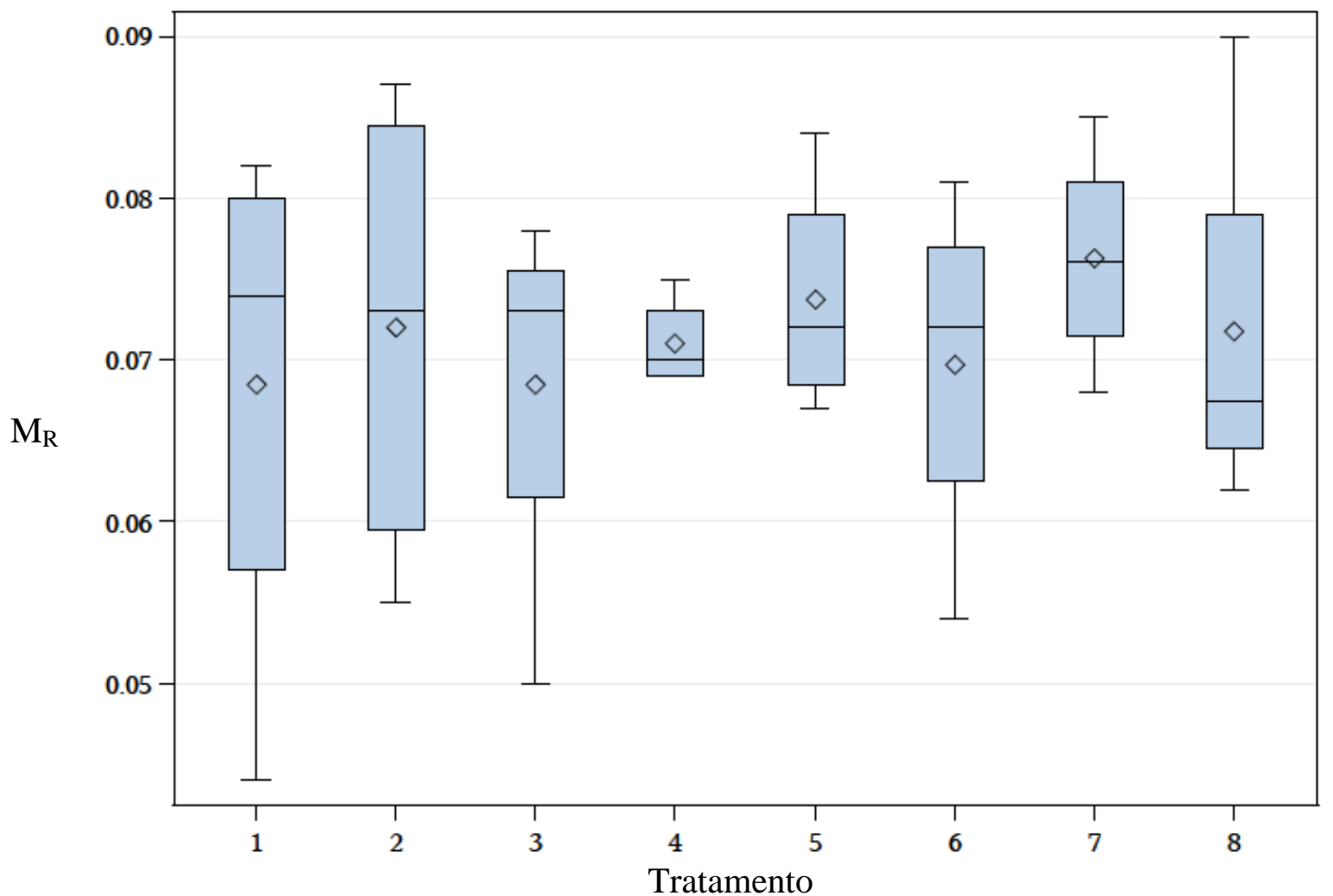

Figura 5 - Valores referentes à massa de matéria seca de parte aérea $\left(M_{A}, g\right)$ e de raiz $\left(M_{R}, g\right)$ de 10 plântulas de soja, aos 4 dias após a semeadura. Laboratório de análise de sementes. Departamento de Produção Vegetal. Escola Superior de Agricultura "Luiz de Queiroz". Universidade de São Paulo. 2013 


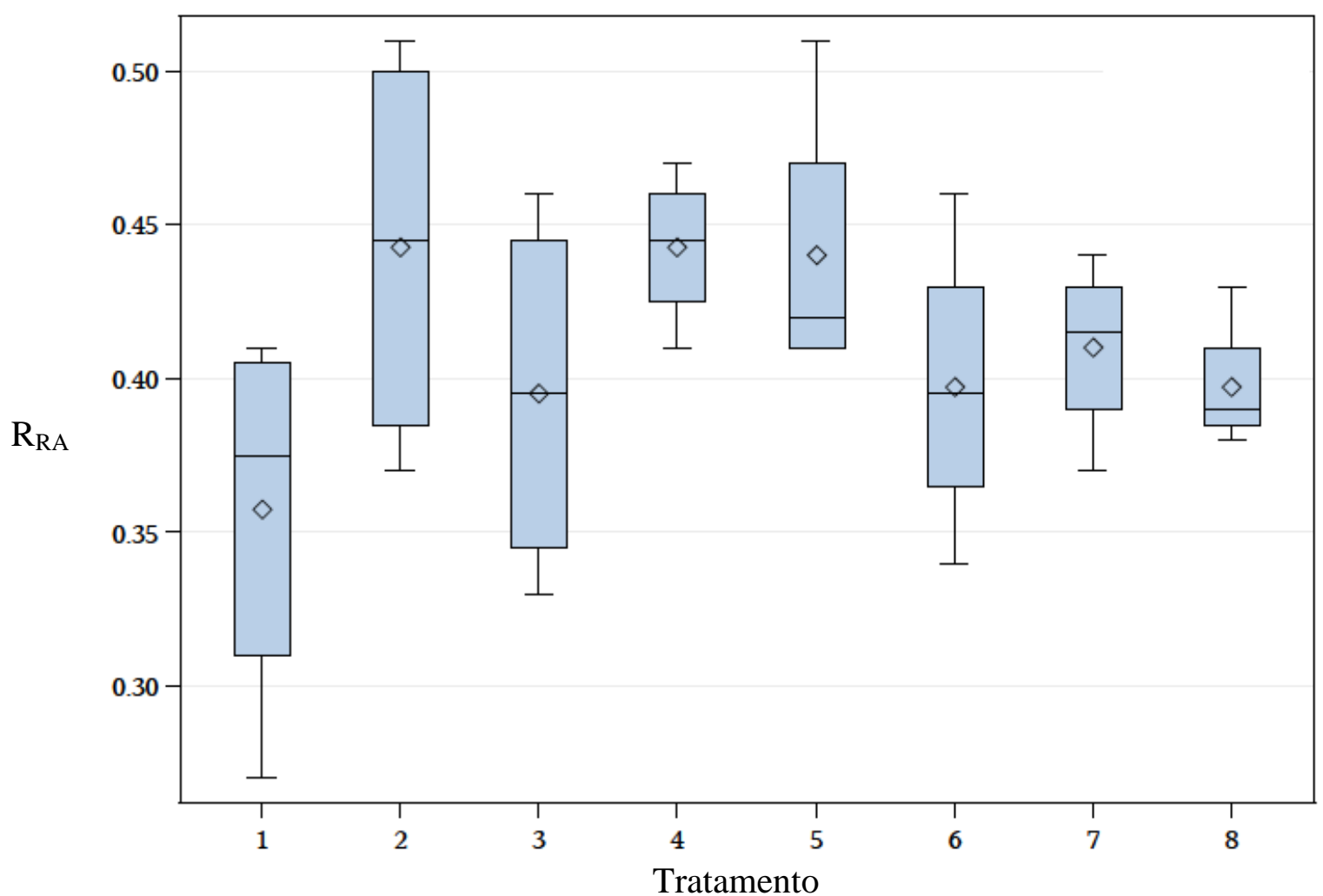

Figura 6 - Valores referentes à relação massa de matéria seca de raiz e parte aérea $\left(R_{R A}, g \cdot g^{-1}\right)$ de plântulas de soja aos 4 dias após a semeadura. Laboratório de análise de sementes. Departamento de Produção Vegetal. Escola Superior de Agricultura "Luiz de Queiroz". Universidade de São Paulo. 2013

\subsubsection{Teste de frio}

No teste de frio (Tabela 9 e Figura 7), observou-se que o tratamento com Fipronil foi o que apresentou melhor tendência de desempenho, mas não diferiu dos mais tratamentos, apenas do tratamento com Fipronil + Piraclostrobina + Tiofanato Metílico. Além disso, foi aferido que todos os tratamentos apresentaram germinação aos 4 dias após a semeadura acima dos $80 \%$ estabelecidos como mínimo necessário para comercialização no Brasil (BRASIL, 2009).

Nas condições climáticas do Brasil não é comum a semeadura da soja em temperaturas baixas. Entretanto, em outros países produtores dessa fabácea (oleaginosa), este pode ser um indicativo de que os produtos testados (sobretudo o Fipronil, seguido pelasas diferentes doses do ingrediente ativo Fluxapiroxade e a Piraclostrobina) não apresentariam quaisquer danos à germinação e ao estabelecimento das plântulas no campo em baixas temperaturas. 
Tabela 9 - Resultados: valores médios referentes à germinação $\left(\mathrm{T}_{\mathrm{F}}, \%\right)$, após o teste de frio (teste de vigor), de plântulas de soja aos 4 dias após a semeadura, e ao coeficiente de variação (CV, \%). Laboratório de análise de sementes. Departamento de Produção Vegetal. Escola Superior de Agricultura "Luiz de Queiroz”. Universidade de São Paulo. 2013

\begin{tabular}{clcc}
\hline $\mathrm{T}$ & Nome técnico (Dose $-\mathrm{g}[\mathrm{i} . \mathrm{a}] ..[100 \mathrm{~kg}$ sementes] & $\mathrm{T}_{\mathrm{F}}$ ) & $\mathrm{Dc}^{1}$ \\
\hline 1 & Controle & 89,0 & $\mathrm{AB}$ \\
2 & Fipronil (50) & 95,0 & $\mathrm{~A}$ \\
3 & Fipronil + Piraclostrobina + Tiofanato Metílico (100) & 87,0 & $\mathrm{~B}$ \\
4 & Fluxapiroxade (15) & 93,0 & $\mathrm{AB}$ \\
5 & Fluxapiroxade (25) & 91,5 & $\mathrm{AB}$ \\
6 & Fluxapiroxade (50) & 92,5 & $\mathrm{AB}$ \\
7 & Fluxapiroxade (75) & 89,5 & $\mathrm{AB}$ \\
8 & Piraclostrobina (10) & 89,5 & $\mathrm{AB}$ \\
\hline $\mathrm{CV}$ & & 4,69 &
\end{tabular}

${ }^{1}$ Médias seguidas pela mesma letra maiúscula não diferem entre si pelo teste de Duncan (Dc) ao nível de significância de $5 \%$

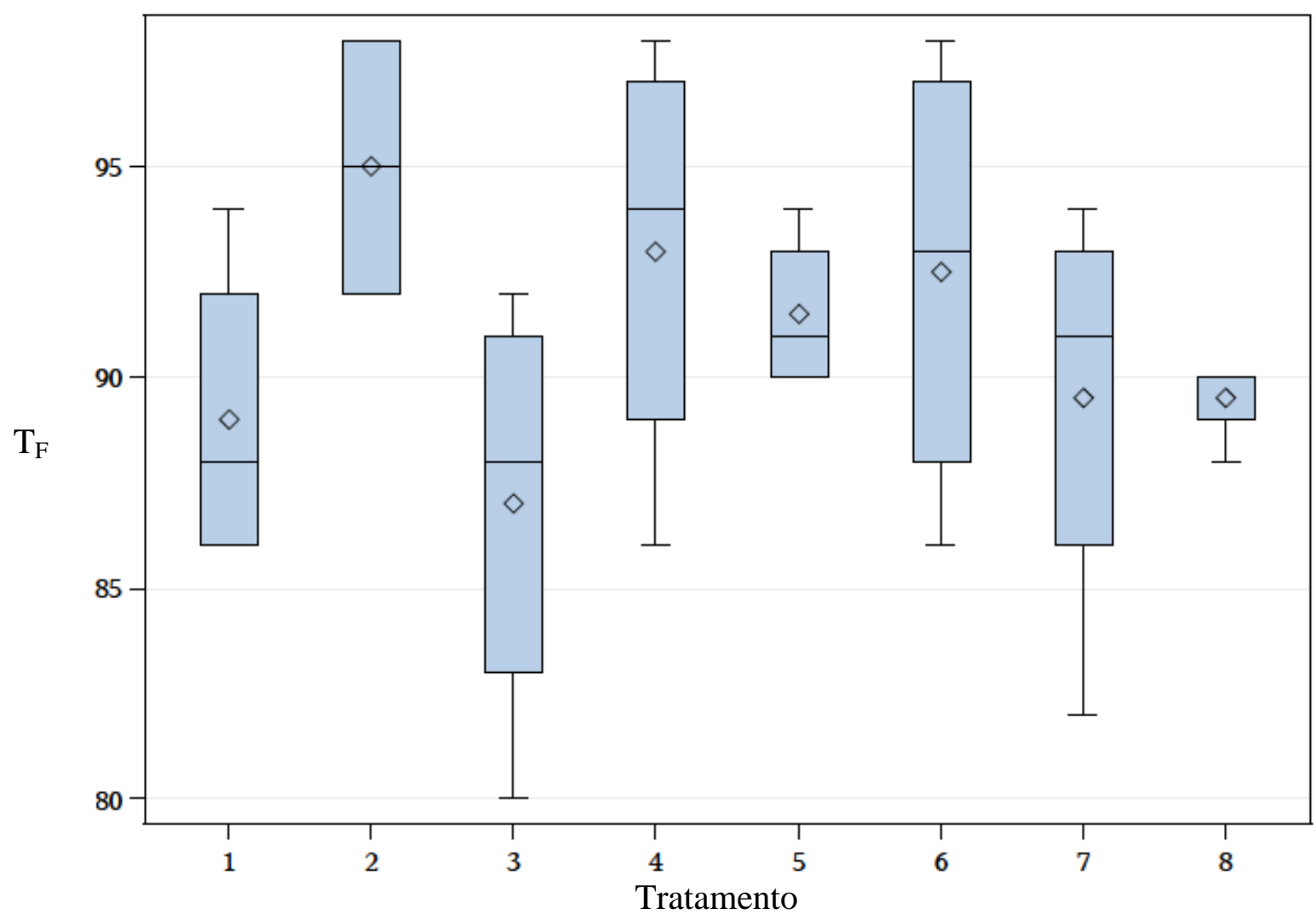

Figura 7 - Resultados: Valores médios (losangos), mínimos, primeiro quartil, medianos, terceiro quartil e máximos referentes à germinação $\left(\mathrm{T}_{\mathrm{F}}, \%\right)$, após o teste de frio (teste de vigor), de plântulas de soja aos 4 dias após a semeadura. Laboratório de análise de sementes. Departamento de Produção Vegetal. Escola Superior de Agricultura “Luiz de Queiroz”. Universidade de São Paulo. 2013 


\subsubsection{Análise de imagem}

Outro método para avaliação do vigor de sementes considerado altamente eficaz e prático consiste na análise de imagens das plântulas com o auxílio do software SVIS (ANEXO 3) (MARCOS FILHO, 1999).

De acordo com os resultados apresentados nas Tabelas 10 e 11, todos os tratamentos apresentaram desempenho semelhante em termos de índice de vigor e de crescimento aos 3 dias após a semeadura (Figuras 8 e 9).

Foram observadas diferenças apenas no índice de uniformidade (Tabela 12 e Figura 10), no qual os tratamentos com Fipronil, Fipronil + Piraclostrobina + Tiofanato Metílico e Fluxapiroxade (15, 25 e $50 \mathrm{~g}$ por $100 \mathrm{~kg}$ de sementes) apresentaram desempenho melhor que o Controle, mas não diferiram dos seguintes tratamentos: Fluxapiroxade $(75$ g por $100 \mathrm{~kg}$ de sementes) e Piraclostrobina em termos de índice de uniformidade aos 3 dias após a semeadura.

Tabela 10 - Resultados: valores médios referentes à análise de imagem ( $\mathrm{Sv}$ - índice de vigor) aos 3 dias após a semeadura de soja e ao coeficiente de variação (CV, \%). Laboratório de análise de sementes. Departamento de Produção Vegetal. Escola Superior de Agricultura “Luiz de Queiroz”. Universidade de São Paulo. 2013

\begin{tabular}{llrc}
\hline $\mathrm{T}$ & Nome técnico (Dose $-\mathrm{g}\left[\right.$ i.a.].[100kg sementes] $\left.{ }^{-1}\right)$ & $\mathrm{Sv}$ & $\mathrm{Dc}^{1}$ \\
\hline 1 & Controle & 858,8 & $\mathrm{~A}$ \\
2 & Fipronil (50) & 928,3 & $\mathrm{~A}$ \\
3 & Fipronil + Piraclostrobina + Tiofanato Metílico (100) & 929,3 & $\mathrm{~A}$ \\
4 & Fluxapiroxade (15) & 936,3 & $\mathrm{~A}$ \\
5 & Fluxapiroxade (25) & 883,5 & $\mathrm{~A}$ \\
6 & Fluxapiroxade (50) & 891,5 & $\mathrm{~A}$ \\
7 & Fluxapiroxade (75) & 885,0 & $\mathrm{~A}$ \\
8 & Piraclostrobina (10) & 894,0 & $\mathrm{~A}$ \\
\hline CV & & 5,33 &
\end{tabular}

${ }^{1}$ Médias seguidas pela mesma letra maiúscula não diferem entre si pelo teste de Duncan (Dc) ao nível de significância de 5\% 
Tabela 11 - Resultados: valores médios referentes à análise de imagem (Sc - índice de crescimento) aos 3 dias após a semeadura de soja ao coeficiente de variação (CV, \%). Laboratório de análise de sementes. Departamento de Produção Vegetal. Escola Superior de Agricultura “Luiz de Queiroz". Universidade de São Paulo. 2013

\begin{tabular}{clcc}
\hline $\mathrm{T}$ & Nome técnico $\left(\right.$ Dose $-\mathrm{g}\left[\right.$ i.a.].[100kg sementes] ${ }^{-1}$ ) & $\mathrm{Sc}$ & $\mathrm{Dc}^{1}$ \\
\hline 1 & Controle & 863,0 & $\mathrm{~A}$ \\
2 & Fipronil (50) & 944,5 & $\mathrm{~A}$ \\
3 & Fipronil + Piraclostrobina + Tiofanato Metílico (100) & 946,3 & $\mathrm{~A}$ \\
4 & Fluxapiroxade (15) & 952,0 & $\mathrm{~A}$ \\
5 & Fluxapiroxade (25) & 880,0 & $\mathrm{~A}$ \\
6 & Fluxapiroxade (50) & 891,5 & $\mathrm{~A}$ \\
7 & Fluxapiroxade (75) & 887,5 & $\mathrm{~A}$ \\
8 & Piraclostrobina (10) & 904,5 & $\mathrm{~A}$ \\
\hline $\mathrm{CV}$ & & 6,90 &
\end{tabular}

${ }^{1}$ Médias seguidas pela mesma letra maiúscula não diferem entre si pelo teste de Duncan (Dc) ao nível de significância de $5 \%$

Tabela 12 - Resultados: valores médios referentes à análise de imagem ( $\mathrm{Su}$ - índice de uniformidade) aos 3 dias após a semeadura de soja e ao coeficiente de variação $(\mathrm{CV}, \%)$. Laboratório de análise de sementes. Departamento de Produção Vegetal. Escola Superior de Agricultura "Luiz de Queiroz". Universidade de São Paulo. 2013

\begin{tabular}{|c|c|c|c|}
\hline $\mathrm{T}$ & Nome técnico (Dose $-\mathrm{g}[\text { i.a.].[100kg sementes] }]^{-1}$ ) & $\mathrm{Su}$ & $\mathrm{Dc}^{1}$ \\
\hline 1 & Controle & 850,5 & $\mathrm{~B}$ \\
\hline 2 & Fipronil (50) & 891,5 & A \\
\hline 3 & Fipronil + Piraclostrobina + Tiofanato Metílico (100) & 891,8 & A \\
\hline 4 & Fluxapiroxade (15) & 900,3 & A \\
\hline 5 & Fluxapiroxade (25) & 893,5 & A \\
\hline 6 & Fluxapiroxade (50) & 892,8 & A \\
\hline 7 & Fluxapiroxade (75) & 880,8 & $\mathrm{AB}$ \\
\hline 8 & Piraclostrobina (10) & 870,5 & $\mathrm{AB}$ \\
\hline
\end{tabular}

${ }^{1}$ Médias seguidas pela mesma letra maiúscula não diferem entre si pelo teste de Duncan (Dc) ao nível de significância de $5 \%$. 


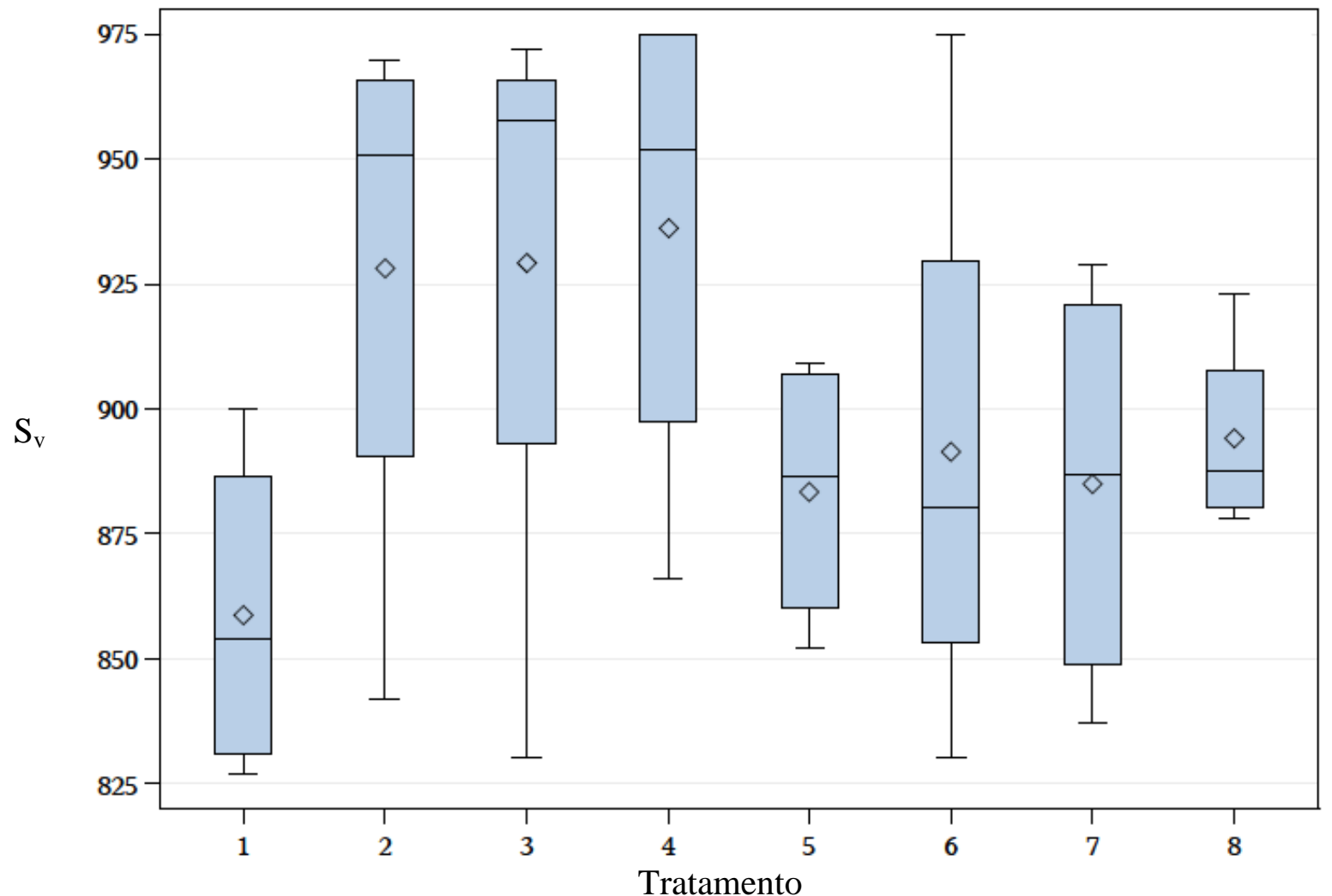

Figura 8 - Resultados: Valores médios (losangos), mínimos, primeiro quartil, medianos, terceiro quartil e máximos referentes à análise de imagem ( $\mathrm{Su}$ - índice de vigor) aos 3 dias após a semeadura de soja. Laboratório de análise de sementes. Departamento de Produção Vegetal. Escola Superior de Agricultura "Luiz de Queiroz". Universidade de São Paulo. 2013

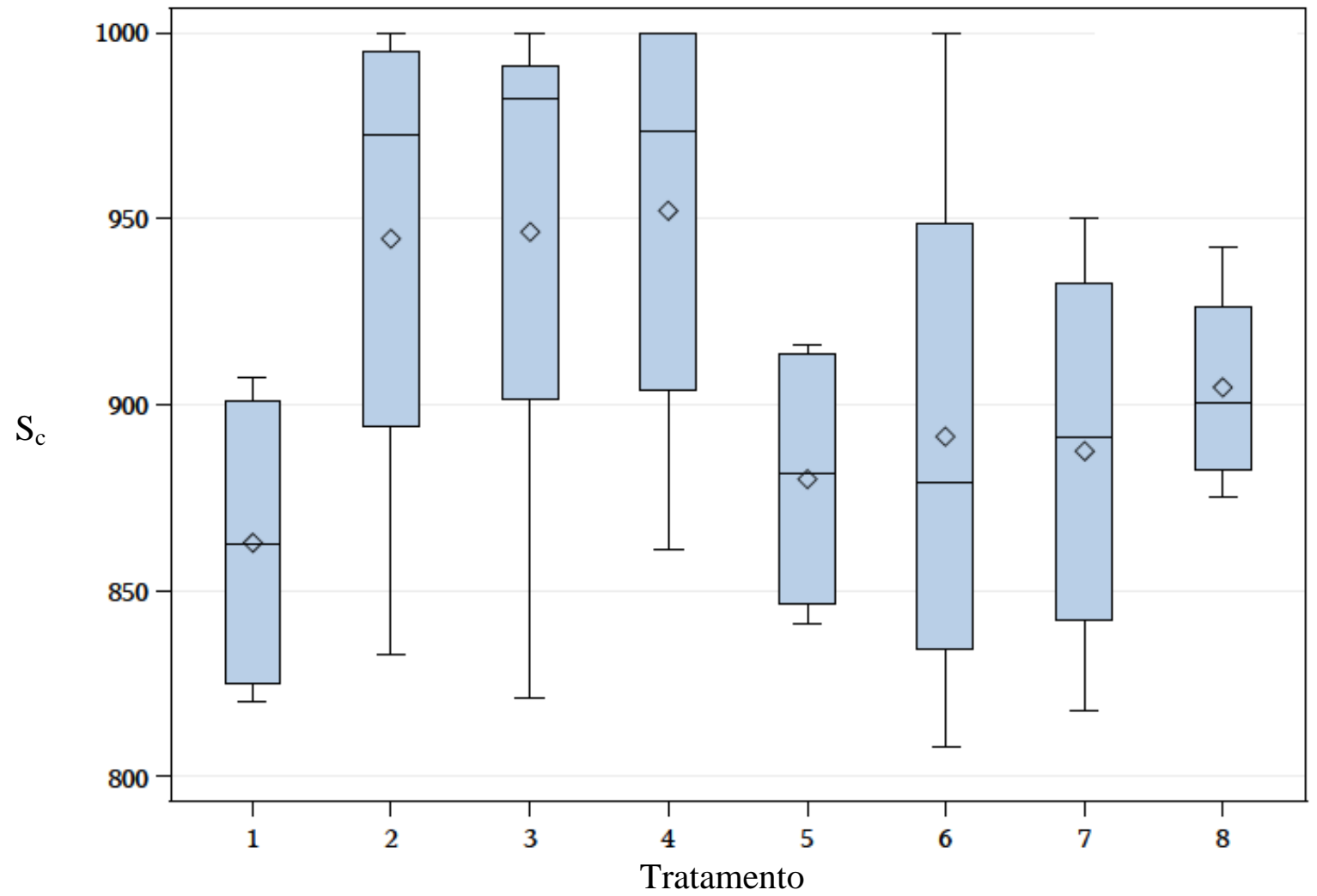

Figura 9 - Resultados: Valores médios (losangos), mínimos, primeiro quartil, medianos, terceiro quartil e máximos referentes à análise de imagem ( $\mathrm{Su}$ - índice de crescimento) aos 3 dias após a semeadura de soja. Laboratório de análise de sementes. Departamento de Produção Vegetal. Escola Superior de Agricultura "Luiz de Queiroz". Universidade de São Paulo. 2013 


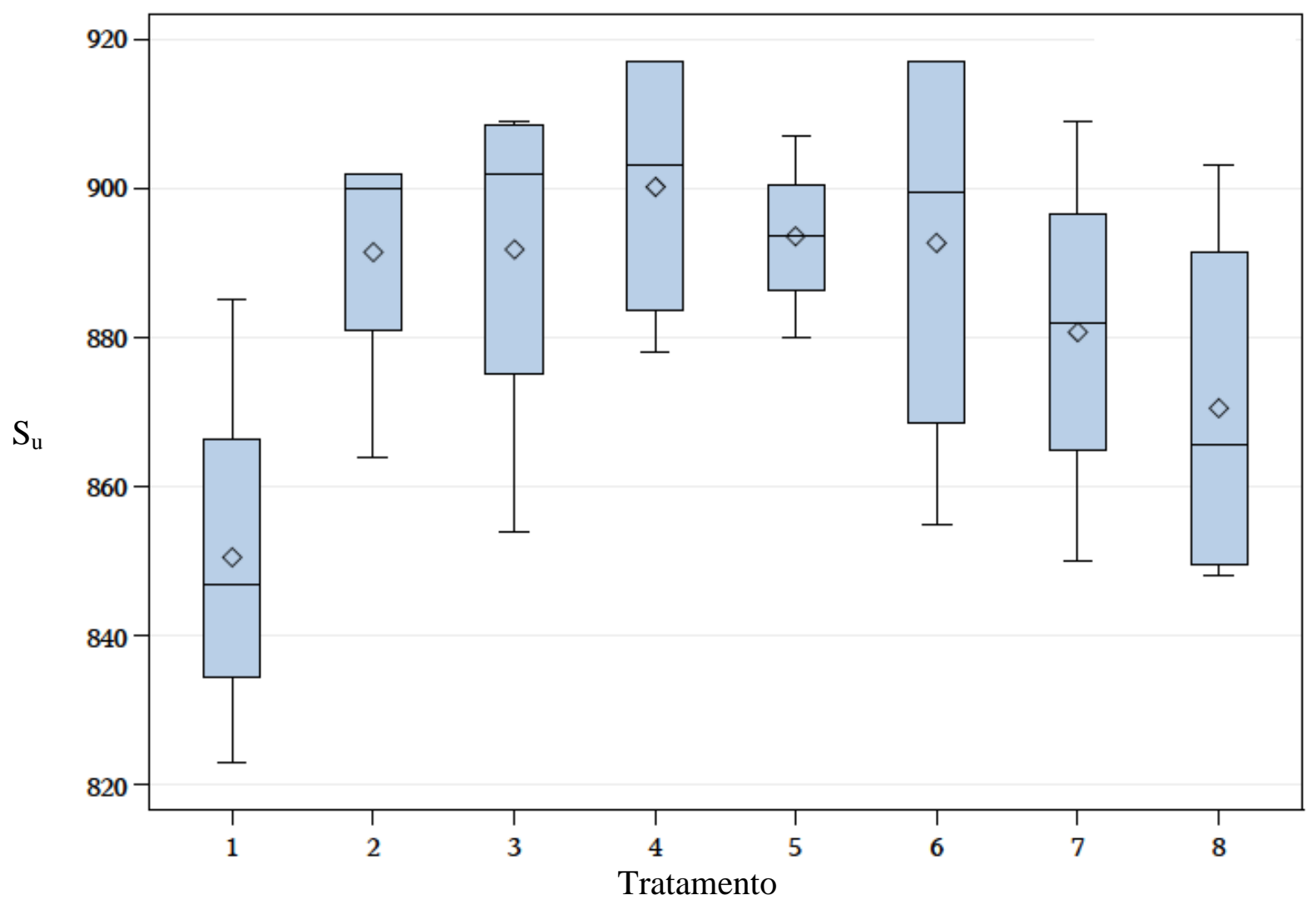

Figura 10 - Resultados: Valores médios (losangos), mínimos, primeiro quartil, medianos, terceiro quartil e máximos referentes à análise de imagem (Su - índice de uniformidade) aos 3 dias após a semeadura de soja. Laboratório de análise de sementes. Departamento de Produção Vegetal. Escola Superior de Agricultura "Luiz de Queiroz". Universidade de São Paulo. 2013

\subsection{Valor Spad e teor de clorofila da folha}

O índice Spad pode ser correlacionado com o teor de clorofila da folha e verificou-se maiores valores nas plântulas de soja com tratamento de sementes utilizando Piraclostrobina, que apresentou desempenho melhor que o Controle, mas não diferiu estatisticamente do tratamento Fluxapiroxade (15 g por $100 \mathrm{~kg}$ de sementes) aos 13 dias após a semeadura (Tabela 13 e Figura 11).

O índice Spad nas plântulas do tramento com Piraclostrobina foi de 41,95, enquanto que no tratamento Controle foi de 36,63 (Tabela 13). Com relação ao teor de clorofila na folha, o mesmo foi de 15,21 nas plântulas de soja com tratamento de sementes utilizando Piraclostrobina e de 14,28 nas plântulas de soja do tratamento Controle. 
Tabela 13 - Resultados: valores médios referentes ao valor SPAD (SPAD) e teor de clorofila (TC, $\mathrm{mg} . \mathrm{L}^{-1}$ ), aos 13 dias após a semeadura de soja, e ao coeficiente de variação (CV, \%). Laboratório de análise de sementes. Departamento de Produção Vegetal. Escola Superior de Agricultura "Luiz de Queiroz". Universidade de São Paulo. 2013

\begin{tabular}{clcccc}
\hline $\mathrm{T}$ & Nome técnico (Dose $-\mathrm{g}[\mathrm{i} . \mathrm{a}.] .[100 \mathrm{~kg} \text { sementes] }]^{-1}$ ) & SPAD & & $\mathrm{TC}$ & $\mathrm{Dc}^{1}$ \\
\hline 1 & Controle & 39,625 & $\mathrm{BC}$ & 14,28 & $\mathrm{BC}$ \\
2 & Fipronil (50) & 39,550 & $\mathrm{C}$ & 14,25 & $\mathrm{C}$ \\
3 & Fipronil + Piraclostrobina + Tiofanato Metílico (100) & 40,650 & $\mathrm{BC}$ & 14,69 & $\mathrm{BC}$ \\
4 & Fluxapiroxade (15) & 40,975 & $\mathrm{AB}$ & 14,82 & $\mathrm{AB}$ \\
5 & Fluxapiroxade (25) & 40,425 & $\mathrm{BC}$ & 14,60 & $\mathrm{BC}$ \\
6 & Fluxapiroxade (50) & 39,525 & $\mathrm{C}$ & 14,24 & $\mathrm{C}$ \\
7 & Fluxapiroxade (75) & 40,275 & $\mathrm{BC}$ & 14,54 & $\mathrm{BC}$ \\
8 & Piraclostrobina (10) & 41,950 & $\mathrm{~A}$ & 15,21 & $\mathrm{~A}$ \\
\hline $\mathrm{CV}$ & & 2,10 & & 2,10 &
\end{tabular}

${ }^{1}$ Médias seguidas pela mesma letra maiúscula não diferem entre si pelo teste de Duncan (Dc) ao nível de significância de 5\%

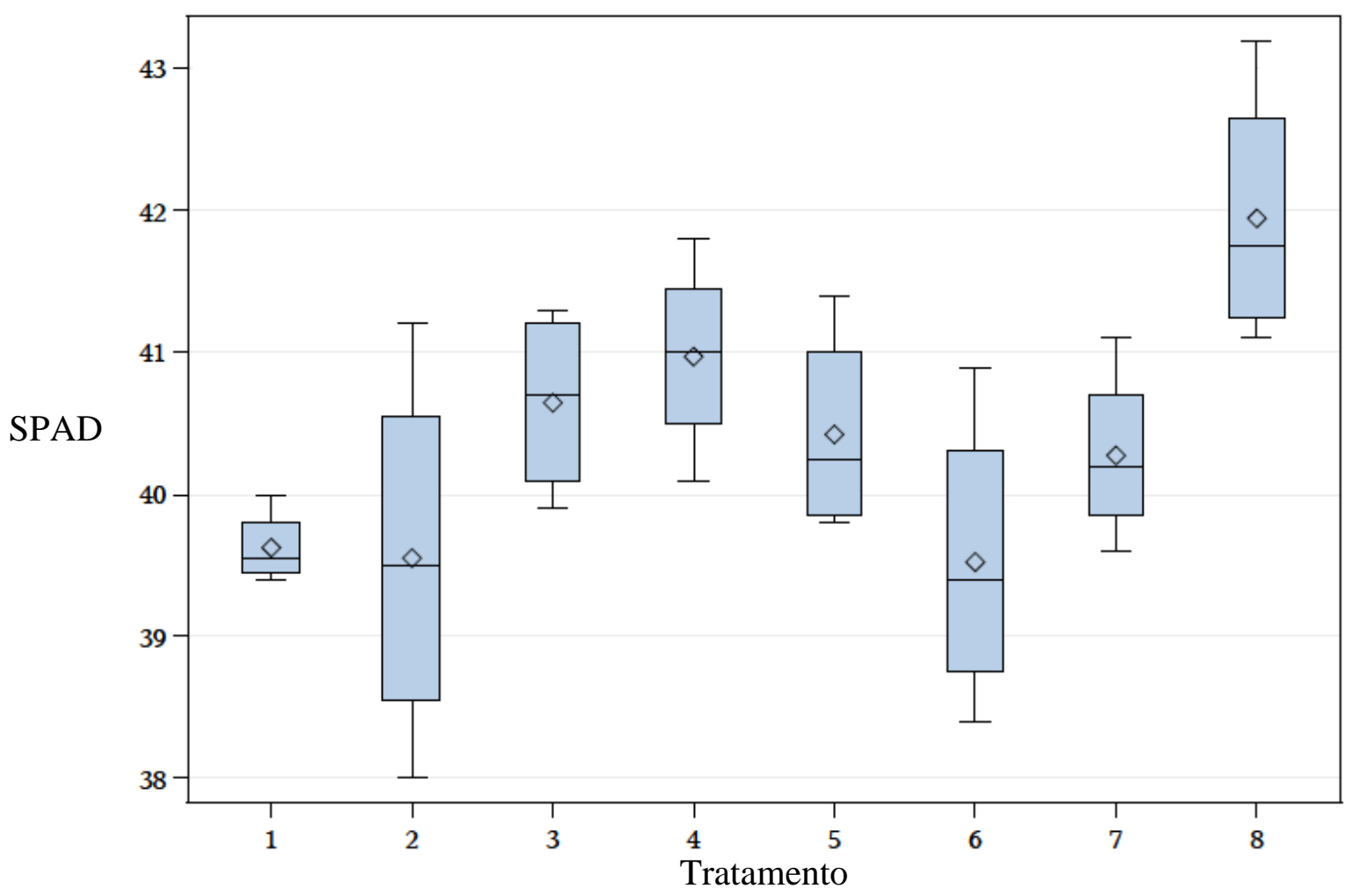

Figura 11 - Valores médios (losangos), mínimos, primeiro quartil, medianos, terceiro quartil e máximos referentes ao valor SPAD (SPAD) aos 13 dias após a semeadura de soja. Laboratório de análise de sementes. Departamento de Produção Vegetal. Escola Superior de Agricultura "Luiz de Queiroz". Universidade de São Paulo. 2013 


\subsection{Proteína e nitrogênio total}

Os maiores valores de proteína e nitrogênio total foram observados no tratamento com Fluxapiroxade (50 g por $100 \mathrm{~kg}$ de sementes), que apresentou melhor desempenho, mas não diferiu dos tratamentos Controle, Fipronil, Fluxapiroxade (25 e 75 g por 100 kg de sementes) e Piraclostrobina (Tabela 14 e Figura 12). Esses resultados corroboram de certa forma com os observados para índice Spad e teor de clorofila na folha (Tabela 13), pois o maior teor de nitrogênio está relacionado à maior atividade da enzima nitrato redutase.

Confore observado na Tabela 13, o tratamento com Piraclostrobina apresentou desempenho superior aos demais e na Tabela 14 este tratamento não diferiu estatisticamente do tratamento com melhor desempenho. As estrobilurinas são compostos secundários com ação mitocondrial específica e estes compostos inibem o transporte de elétrons entre o citocromo b e o citocromo $\mathbf{c}$ na cadeia transportadora de elétrons, causando diminuição na produção de ATP (ANKE, 1995). Devido à inibição na cadeia transportadora ocorre à acidificação no citoplasma, aumentando assim a atividade da enzima nitrato redutase e consequentemente da assimilação de nitrogênio

Tabela 14 - Resultados: valores médios referentes ao teor de proteína $\left(\mathrm{T}_{\mathrm{P}}, \mathrm{mg} \cdot \mathrm{mL}^{-1}\right)$, e teor de nitrogênio total $\left(\mathrm{T}_{\mathrm{N}}, \mathrm{mg} \cdot \mathrm{mL}^{-1}\right)$ aos 11 dias após a semeadura de soja e ao coeficiente de variação $(\mathrm{CV}, \%)$. Laboratório de análise de sementes. Departamento de Produção Vegetal. Escola Superior de Agricultura "Luiz de Queiroz". Universidade de São Paulo. 2013

\begin{tabular}{clcccc}
\hline $\mathrm{T}$ & Nome técnico (Dose $-\mathrm{g}$ [i.a.].[100kg sementes] $]^{-1}$ ) & $\mathrm{T}_{\mathrm{P}}$ & $\mathrm{Dc}$ & $\mathrm{T}_{\mathrm{N}}$ & $\mathrm{Dc}^{1}$ \\
\hline 1 & Controle & 8,575 & $\mathrm{AB}$ & 1,372 & $\mathrm{AB}$ \\
2 & Fipronil (50) & 7,375 & $\mathrm{ABC}$ & 1,180 & $\mathrm{ABC}$ \\
3 & Fipronil + Piraclostrobina + Tiofanato Metílico (100) & 5,503 & $\mathrm{C}$ & 0,880 & $\mathrm{C}$ \\
4 & Fluxapiroxade (15) & 6,460 & $\mathrm{BC}$ & 1,034 & $\mathrm{BC}$ \\
5 & Fluxapiroxade (25) & 8,284 & $\mathrm{AB}$ & 1,325 & $\mathrm{AB}$ \\
6 & Fluxapiroxade (50) & 9,207 & $\mathrm{~A}$ & 1,473 & $\mathrm{~A}$ \\
7 & Fluxapiroxade (75) & 7,227 & $\mathrm{ABC}$ & 1,156 & $\mathrm{ABC}$ \\
8 & Piraclostrobina (10) & 7,381 & $\mathrm{ABC}$ & 1,181 & $\mathrm{ABC}$ \\
\hline $\mathrm{CV}$ & & 17,80 & & 17,80 &
\end{tabular}

${ }^{1}$ Médias seguidas pela mesma letra maiúscula não diferem entre si pelo teste de Duncan (Dc) ao nível de significância de 5\% 


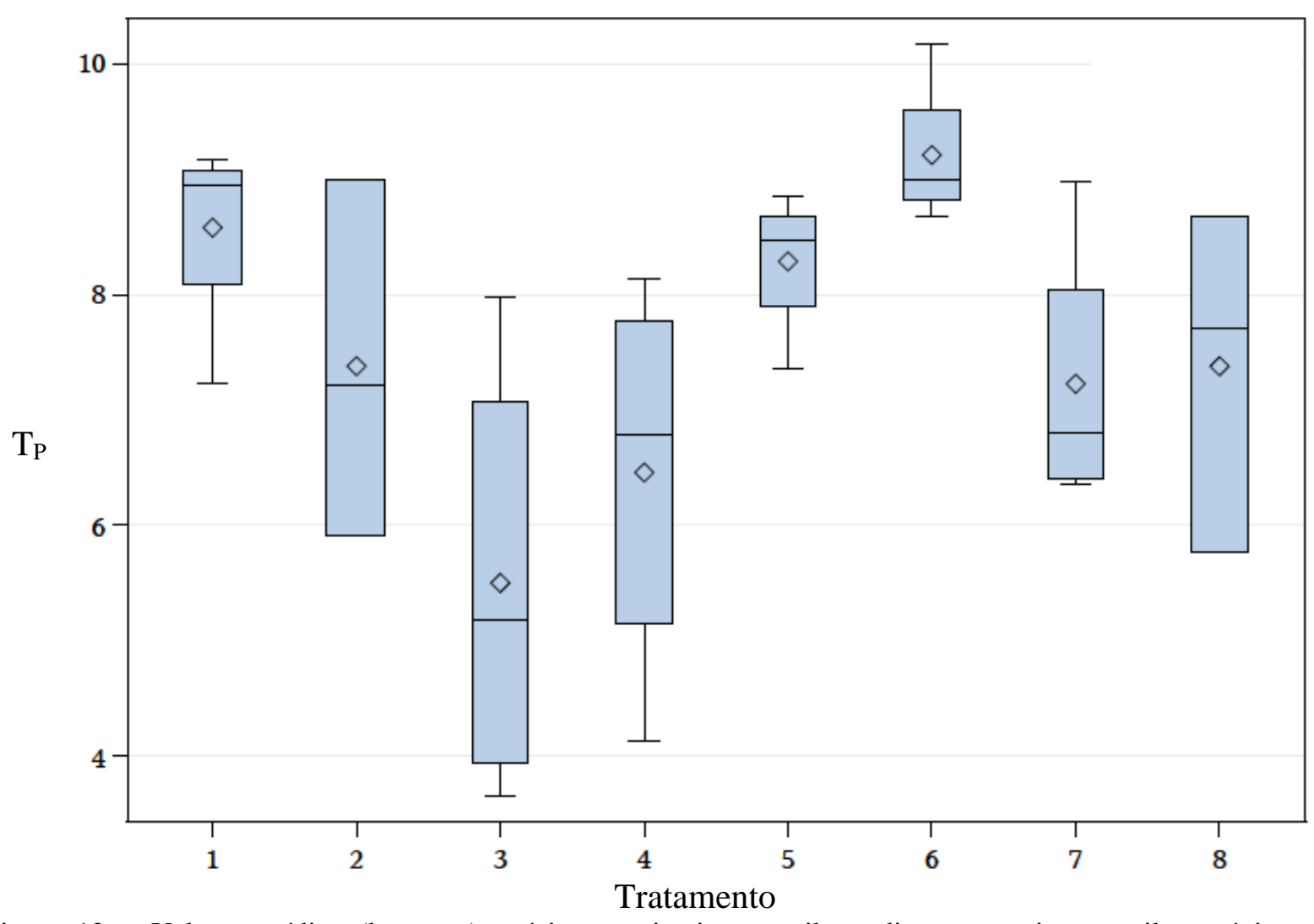

Figura 12 - Valores médios (losangos), mínimos, primeiro quartil, medianos, terceiro quartil e máximos referentes ao teor de proteína $\left(\mathrm{T}_{\mathrm{P}}, \mathrm{mg} \cdot \mathrm{mL}^{-1}\right)$ aos 11 dias após a semeadura de soja. Laboratório de análise de sementes. Departamento de Produção Vegetal. Escola Superior de Agricultura "Luiz de Queiroz”. Universidade de São Paulo. 2013

\subsection{Trocas gasosas}

\subsubsection{Assimilação de $\mathrm{CO}_{2}$}

Verificou-se na avaliação de trocas gasosas que os valores de assimilação de $\mathrm{CO}_{2}$ são negativos, ou seja, a respiração das plântulas de soja foi maior que a fotossíntese bruta. Contudo, os valores de assimilação de $\mathrm{CO}_{2}$ observados nas plântulas de soja com tratamento de sementes utilizando Piraclostrobina foram menos negativos e apresentaram desempenho melhor que o Controle e os demais tratamentos, mas não diferiram dos tratamentos Fluxapiroxade (15 e $75 \mathrm{~g}$ por $100 \mathrm{~kg}$ de sementes) (Tabela 15 e Figura 13).

Os valores de assimilação de $\mathrm{CO}_{2}$ observados foram em média de -1,217 $\mu$ mol $\left(\mathrm{CO}_{2}\right) \cdot \mathrm{m}^{-2} \cdot \mathrm{s}^{-1}$ para o tratamento Piraclostrobina e $-2,075 \mu \mathrm{mol}\left(\mathrm{CO}_{2}\right) \cdot \mathrm{m}^{-2} \cdot \mathrm{s}^{-1}$ para o tratamento Controle.

O incremento na taxa fotossintética observado para o tratamento com Piraclostrobina estaria relacionado principalmente com a inibição parcial na respiração celular ocasionada pela estrobilurina (FAGAN, 2007). As estrobilurinas são compostos químicos extraídos do fungo Strobilurus tenacellus, classificados como inibidores de quinona oxidase (QoI) e sua 
toxicidade ocorre em plantas através da inibição parcial da respiração mitocondrial bloqueando a transferência de elétrons do complexo III (complexo bc1) da cadeia transportadora de elétrons (AMMERMANN et al., 2000; GHINI; KIMATI, 2000, PARREIRA; NEVES; ZAMBOLIM, 2009), o que pode explicar os valores menos negativos na assimilação de $\mathrm{CO}_{2}$.

Tabela 15 - Resultados: valores médios referentes à fotossíntese $\left(\mathrm{FL}, \mu \mathrm{mol} . \mathrm{m}^{-2} \cdot \mathrm{s}^{-1}\right.$ ), aos 15 dias após a semeadura de soja, e ao coeficiente de variação (CV, \%). Laboratório de análise de sementes. Departamento de Produção Vegetal. Escola Superior de Agricultura "Luiz de Queiroz". Universidade de São Paulo. 2013

\begin{tabular}{clrc}
\hline $\mathrm{T}$ & Nome técnico (Dose $\left.-\mathrm{g}[\mathrm{i} . \mathrm{a}.] .[100 \mathrm{~kg} \text { sementes] }]^{-1}\right)$ & $\mathrm{FL}$ & $\mathrm{Dc}^{1}$ \\
\hline 1 & Controle & $-2,075$ & $\mathrm{BC}$ \\
2 & Fipronil (50) & $-2,627$ & $\mathrm{C}$ \\
3 & Fipronil + Piraclostrobina + Tiofanato Metílico (100) & $-1,908$ & $\mathrm{~B}$ \\
4 & Fluxapiroxade (15) & $-1,641$ & $\mathrm{AB}$ \\
5 & Fluxapiroxade (25) & $-1,891$ & $\mathrm{~B}$ \\
6 & Fluxapiroxade (50) & $-2,246$ & $\mathrm{BC}$ \\
7 & Fluxapiroxade (75) & $-1,711$ & $\mathrm{AB}$ \\
8 & Piraclostrobina (10) & $-1,217$ & $\mathrm{~A}$ \\
\hline $\mathrm{CV}$ & & $-21,11$ &
\end{tabular}

${ }^{1}$ Médias seguidas pela mesma letra maiúscula não diferem entre si pelo teste de Duncan (Dc) ao nível de significância de $5 \%$ 


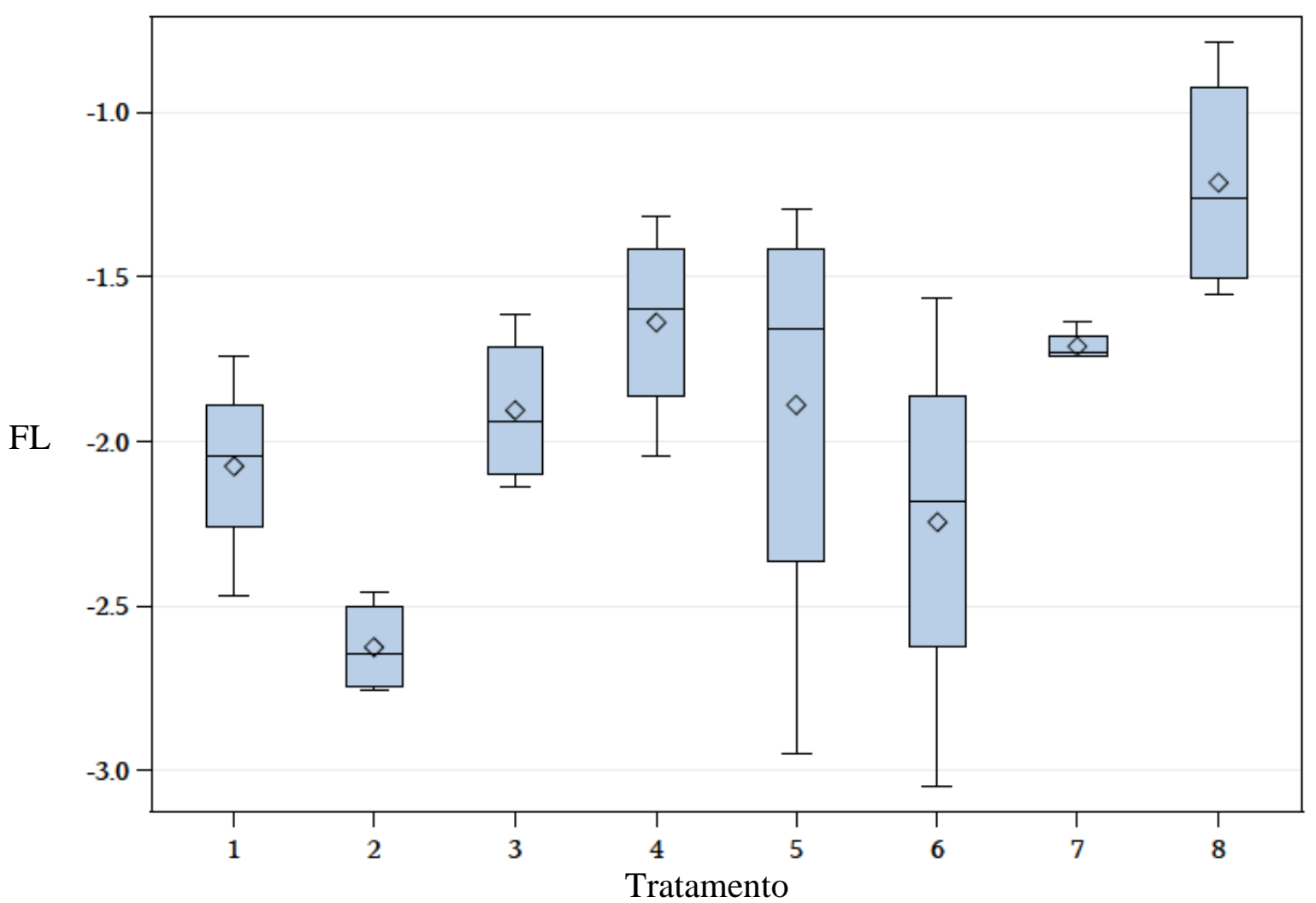

Figura 13 - Valores médios (losangos), mínimos, primeiro quartil, medianos, terceiro quartil e máximos referentes à fotossíntese $\left(\mathrm{FL}, \mu \mathrm{mol} \cdot \mathrm{m}^{-2} \cdot \mathrm{s}^{-1}\right)$ aos 15 dias após a semeadura de soja. Laboratório de análise de sementes. Departamento de Produção Vegetal. Escola Superior de Agricultura "Luiz de Queiroz”. Universidade de São Paulo. 2013

\subsubsection{Condutância estomática}

A condutância estomática foi menor nas plântulas de soja com tratamento de sementes utilizando Piraclostrobina e Fluxapiroxade (25 g por $100 \mathrm{~kg}$ de sementes) (Tabela 16). Observa-se que a condutância estomática destas plântulas foi em média de 0,034 $\mathrm{mmol}\left[\mathrm{H}_{2} \mathrm{O}\right] \cdot \mathrm{m}^{-2} \cdot \mathrm{s}^{-1}$, em ambos os tratamentos. $\mathrm{O}$ tratamento com Fipronil, em contra partida apresentou o maior em termos de condutância estomática e transpiração aos 15 dias após a semeadura (Tabela 16 e Figura 14). 
Tabela 16 - Resultados: valores médios referentes à condutância estomática $\left(\mathrm{CE}, \mu \mathrm{mol} \cdot \mathrm{m}^{-2} \cdot \mathrm{s}^{-1}\right)$, aos 15 dias após a semeadura de soja, e ao coeficiente de variação (CV, \%). Laboratório de análise de sementes. Departamento de Produção Vegetal. Escola Superior de Agricultura "Luiz de Queiroz". Universidade de São Paulo. 2013

\begin{tabular}{clcc}
\hline $\mathrm{T}$ & Nome técnico (Dose $\left.-\mathrm{g}[\mathrm{i} . \mathrm{a}.] .[100 \mathrm{~kg} \text { sementes] }]^{-1}\right)$ & $\mathrm{CE}$ & $\mathrm{Dc}^{1}$ \\
\hline 1 & Controle & 0,061 & $\mathrm{BC}$ \\
2 & Fipronil (50) & 0,122 & $\mathrm{~A}$ \\
3 & Fipronil + Piraclostrobina + Tiofanato Metílico (100) & 0,058 & $\mathrm{BC}$ \\
4 & Fluxapiroxade (15) & 0,044 & $\mathrm{BC}$ \\
5 & Fluxapiroxade (25) & 0,034 & $\mathrm{C}$ \\
6 & Fluxapiroxade (50) & 0,078 & $\mathrm{~B}$ \\
7 & Fluxapiroxade (75) & 0,048 & $\mathrm{BC}$ \\
8 & Piraclostrobina (10) & 0,034 & $\mathrm{C}$ \\
\hline $\mathrm{CV}$ & & 41,39 &
\end{tabular}

${ }^{1}$ Médias seguidas pela mesma letra maiúscula não diferem entre si pelo teste de Duncan (Dc) ao nível de significância de $5 \%$

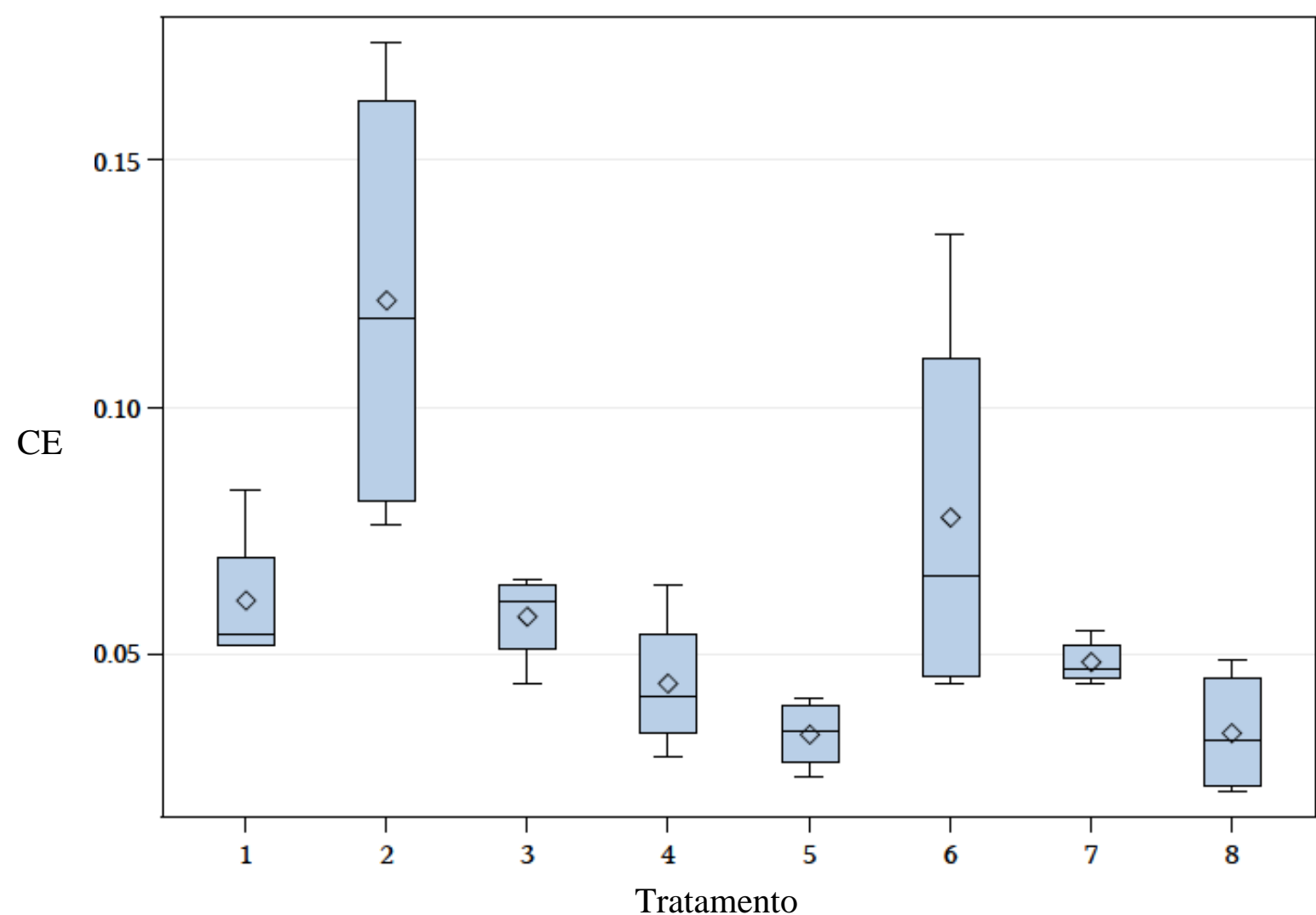

Figura 14 - Valores médios (losangos), mínimos, primeiro quartil, medianos, terceiro quartil e máximos referentes à condutância estomática $\left(\mathrm{CE}, \mu \mathrm{mol} . \mathrm{m}^{-2} \cdot \mathrm{s}^{-1}\right)$ aos 15 dias após a semeadura de soja. Laboratório de análise de sementes. Departamento de Produção Vegetal. Escola Superior de Agricultura “Luiz de Queiroz”. Universidade de São Paulo. 2013 


\subsubsection{Transpiração}

Com relação à transpiração, o tratamento de sementes com Piraclostrobina proporcionou decréscimos na taxa transpiratória das plântulas de soja (Tabela 17 e Figura 15). Nessas plantas, a transpiração foi de $1,210 \mathrm{mmol}\left[\mathrm{H}_{2} \mathrm{O}\right] \cdot \mathrm{m}^{-2} \cdot \mathrm{s}^{-1}$, verificando-se uma redução média da taxa transpiratória de $34 \%$ em relação ao tratamento Controle (Tabela 17). Estes valores não diferiram estatisticamente dos tratamentos com Fluxapiroxade (15, 25 e 75 g por 100 kg de sementes), Fipronil + Piraclostrobina + Tiofanato Metílico e Controle.

Desta forma, contatou-se que o uso da Piraclostrobina foi eficiente na redução da perda de água pelo processo transpiratório. Embora essa redução seja considerada benéfica, demonstra um fechamento parcial dos estômatos, o que poderia limitar a entrada de $\mathrm{CO}_{2}$. Contudo, comparando esses valores com os observados para fotossíntese líquida (assimilação de $\mathrm{CO}_{2}$ ) pode-se verificar que este efeito não prejudicou a taxa de assimilação de $\mathrm{CO}_{2}$. Portanto, essas plântulas podem ser consideradas como eficientes no que diz respeito ao uso da água, pois a água perdida para o ambiente foi menor quando comparadas ao tratamento Controle, sem que tenha sido comprometida a absorção de $\mathrm{CO}_{2}$ para a fotossíntese.

Tabela 17 - Resultados: valores médios referentes à transpiração $\left(\mathrm{TR}, \mathrm{mmol} \cdot \mathrm{m}^{-2} \cdot \mathrm{s}^{-1}\right)$, aos 15 dias após a semeadura de soja, e ao coeficiente de variação (CV, \%). Laboratório de análise de sementes. Departamento de Produção Vegetal. Escola Superior de Agricultura “Luiz de Queiroz". Universidade de São Paulo. 2013

\begin{tabular}{|c|c|c|c|}
\hline $\mathrm{T}$ & Nome técnico (Dose - g[i.a.].[100kg sementes $]^{-1}$ ) & TR & $\mathrm{Dc}^{1}$ \\
\hline 1 & Controle & 1,830 & $\mathrm{BC}$ \\
\hline 2 & Fipronil (50) & 3,082 & A \\
\hline 3 & Fipronil + Piraclostrobina + Tiofanato Metílico (100) & 1,703 & $\mathrm{BC}$ \\
\hline 4 & Fluxapiroxade (15) & 1,379 & $\mathrm{C}$ \\
\hline 5 & Fluxapiroxade (25) & 1,207 & $\mathrm{C}$ \\
\hline 6 & Fluxapiroxade (50) & 2,173 & $\mathrm{~B}$ \\
\hline 7 & Fluxapiroxade (75) & 1,536 & $\mathrm{BC}$ \\
\hline 8 & Piraclostrobina (10) & 1,210 & $\mathrm{C}$ \\
\hline $\mathrm{CV}$ & & 23,92 & \\
\hline
\end{tabular}




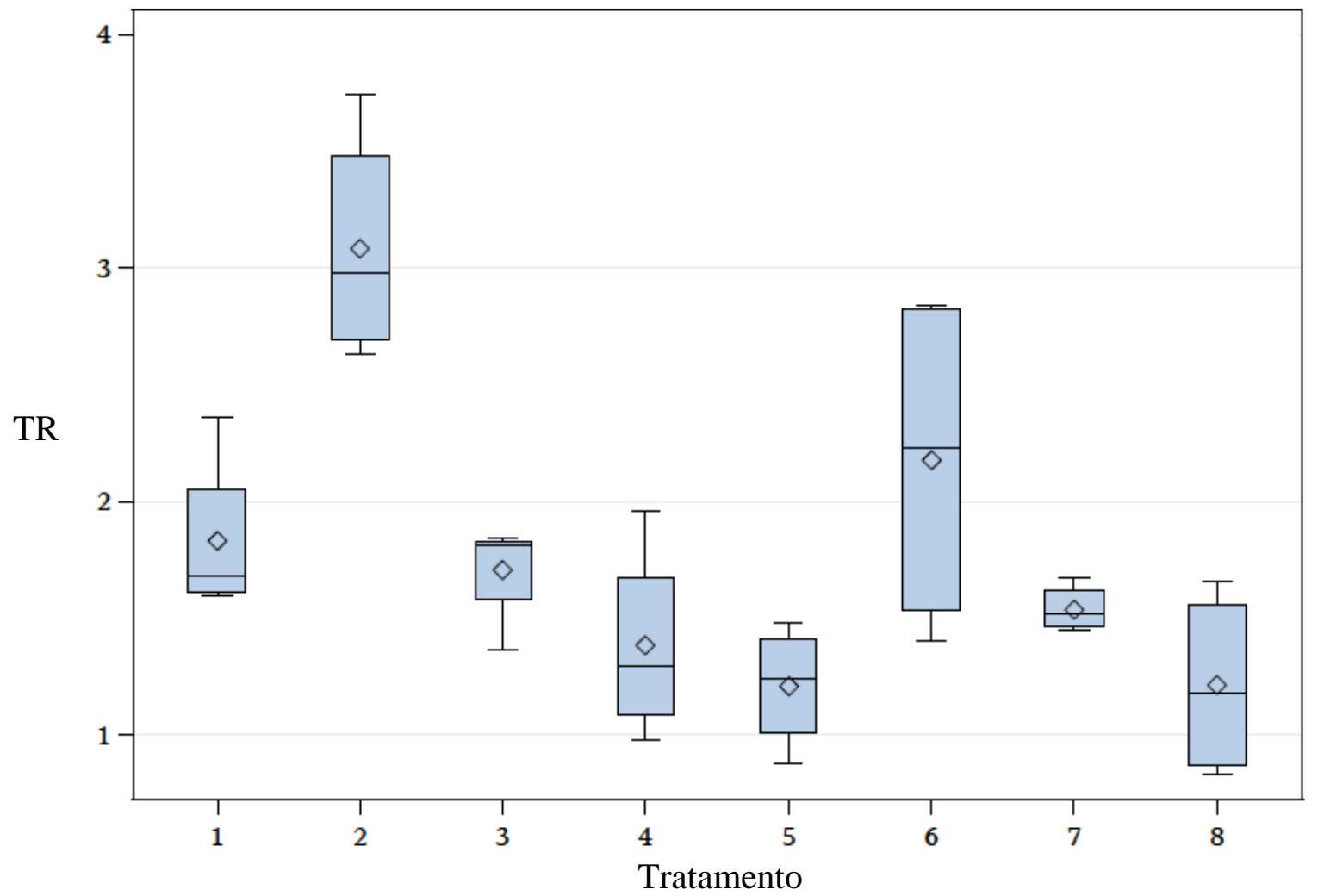

Figura 15 - Valores médios (losangos), mínimos, primeiro quartil, medianos, terceiro quartil e máximos referentes à transpiração $\left(\mathrm{TR}, \mathrm{mmol} \cdot \mathrm{m}^{-2} \cdot \mathrm{s}^{-1}\right)$ aos 15 dias após a semeadura de soja. Laboratório de análise de sementes. Departamento de Produção Vegetal. Escola Superior de Agricultura "Luiz de Queiroz". Universidade de São Paulo. 2013

\subsection{Temperatura foliar}

A temperatura da folha foi maior nas plântulas de soja com tratamento de sementes utilizando Piraclostrobina, mas não diferiu do tratamento Fluxapiroxade (25 g por 100 kg de sementes), caracterizando assim um efeito de aquecimento, nessas plantas (Tabela 18 e Figura 16). A temperatura foi em média de $2,64{ }^{\circ} \mathrm{C}$ maior quando comparadas ao tratamento Controle. Isso pode ser explicado pela baixa taxa transpiratória dessas plantas, pois a água apresenta elevado calor latente de vaporização o que durante a transpiração possibilita o arrefecimento da planta. 
Tabela 18 - Resultados: valores médios referentes à temperatura da folha $\left(\mathrm{Tf},{ }^{\circ} \mathrm{C}\right)$, aos 15 dias após a semeadura de soja, e ao coeficiente de variação $(\mathrm{CV}, \%)$. Laboratório de análise de sementes. Departamento de Produção Vegetal. Escola Superior de Agricultura "Luiz de Queiroz". Universidade de São Paulo. 2013

\begin{tabular}{clcc}
\hline $\mathrm{T}$ & Nome técnico (Dose $\left.-\mathrm{g}[\text { i.a.].[100kg sementes] }]^{-1}\right)$ & $\mathrm{Tf}$ & $\mathrm{Dc}^{1}$ \\
\hline 1 & Controle & 30,350 & $\mathrm{C}$ \\
2 & Fipronil (50) & 29,314 & $\mathrm{C}$ \\
3 & Fipronil + Piraclostrobina + Tiofanato Metílico (100) & 29,734 & $\mathrm{C}$ \\
4 & Fluxapiroxade (15) & 30,303 & $\mathrm{C}$ \\
5 & Fluxapiroxade (25) & 32,450 & $\mathrm{AB}$ \\
6 & Fluxapiroxade (50) & 29,642 & $\mathrm{C}$ \\
7 & Fluxapiroxade (75) & 31,021 & $\mathrm{BC}$ \\
8 & Piraclostrobina (10) & 32,990 & $\mathrm{~A}$ \\
\hline $\mathrm{CV}$ & & 3,89 &
\end{tabular}

${ }^{1}$ Médias seguidas pela mesma letra maiúscula não diferem entre si pelo teste de Duncan (Dc) ao nível de significância de $5 \%$

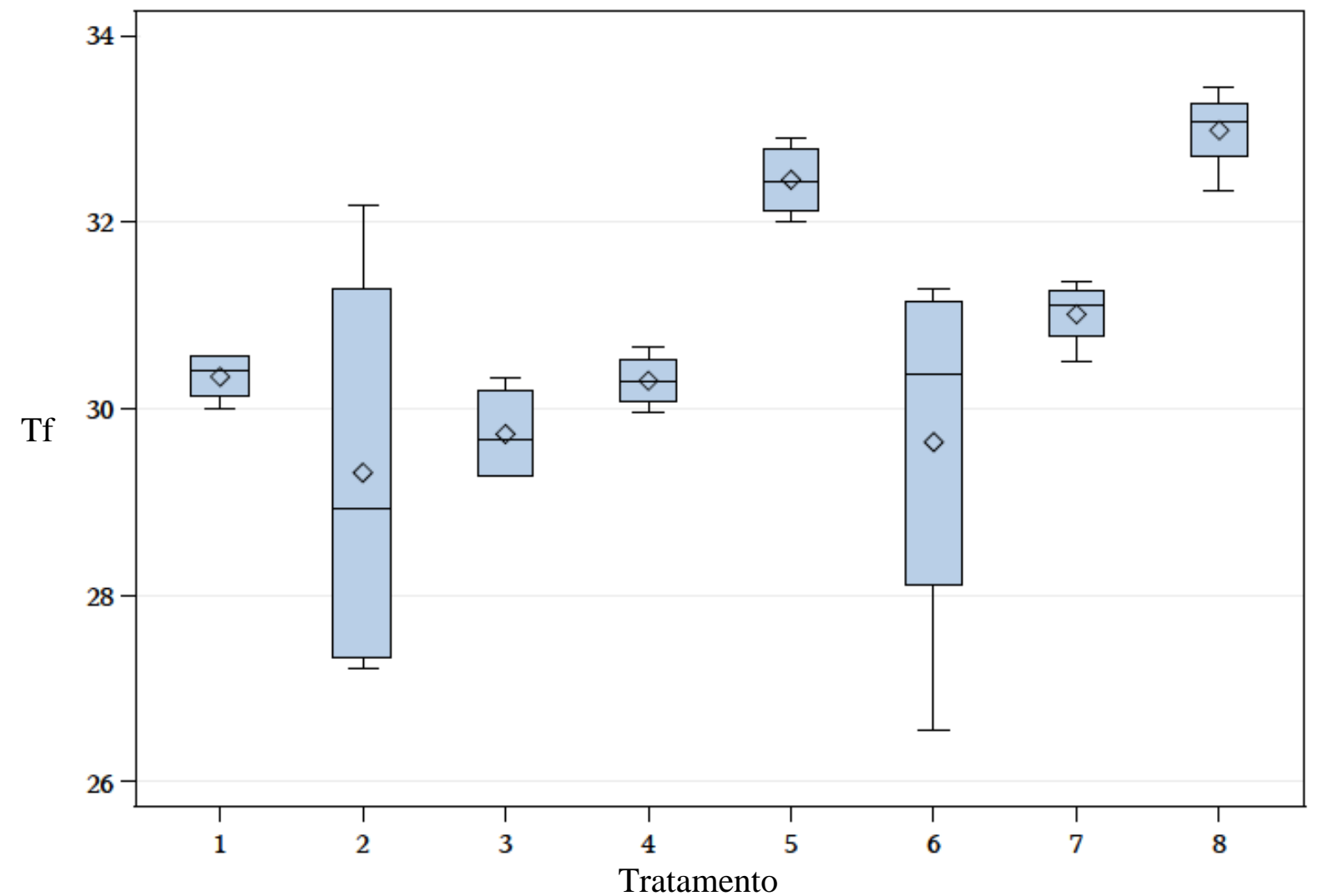

Figura 16 - Valores médios (losangos), mínimos, primeiro quartil, medianos, terceiro quartil e máximos referentes à temperatura da folha $\left(\mathrm{Tf},{ }^{\circ} \mathrm{C}\right)$ aos 15 dias após a semeadura de soja. Laboratório de análise de sementes. Departamento de Produção Vegetal. Escola Superior de Agricultura "Luiz de Queiroz”. Universidade de São Paulo. 2013 


\subsection{Peróxido de hidrogênio}

Observa-se na Tabela 19 e Figura 17 que as plântulas de soja, com tratamento de sementes utilizando Piraclostrobina e Fipronil, apresentaram maior quantidade de peróxido de hidrogênio quando comparados ao tratamento Controle, mas não diferiram dos seguintes tratamentos: Fipronil + Piraclostrobina + Tiofanato Metílico e Fluxapiroxade (25, 50 e 75 g por $100 \mathrm{~kg}$ de sementes).

O peróxido de hidrogênio é considerado um radical livre que, posteriormente, é transformado em $\mathrm{H}_{2} \mathrm{O}$ por enzimas antioxidantes, como por exemplo, a peroxidase e a catalase. Os maiores valores de peróxido de hidrogênio estão relacionados com o incremento na atividade de enzimas antioxidades, sobretudo a superóxido dismutase, que catalisa a transformação do radical $\mathrm{O}_{2}$.

Portanto, pode considerar-se que ocorreu aumento da atividade da superóxido dismutase nas plântulas de soja com tratamento de sementes utilizando Piraclostrobina, pois apresentaram elevada quantidade de peróxido de hidrogênio (Tabela 19), o que possibilitaria o incremento da tolerância dessas plantas ao estresse ambiental. Esses resultados corroboram com Rodrigues (2009), que verificou aumento na atividade da superóxido dismutase após aplicação de Piraclostrobina, em comparação ao tratamento Controle e à aplicação de um fungicida do grupo dos triazóis.

Tabela 19 - Resultados: valores médios referentes ao conteúdo de peróxido de hidrogênio $\left(\mathrm{H}_{2} \mathrm{O}_{2}\right)\left(\mathrm{P}_{\mathrm{H}}\right.$, $\mu$ mol $\left[\mathrm{H}_{2} \mathrm{O}_{2}\right] \cdot \mathrm{g}^{-1}$ de matéria fresca) aos 11 dias após a semeadura de soja e ao coeficiente de variação $(\mathrm{CV}, \%)$. Laboratório de análise de sementes. Departamento de Produção Vegetal. Escola Superior de Agricultura "Luiz de Queiroz". Universidade de São Paulo. 2013

\begin{tabular}{clcc}
\hline $\mathrm{T}$ & Nome técnico (Dose $\left.-\mathrm{g}[\mathrm{i} . \mathrm{a}.] .[100 \mathrm{~kg} \text { sementes }]^{-1}\right)$ & $\mathrm{P}_{\mathrm{H}}$ & $\mathrm{Dc}^{1}$ \\
\hline 1 & Controle & 826,740 & $\mathrm{C}$ \\
2 & Fipronil (50) & 1157,680 & $\mathrm{~A}$ \\
3 & Fipronil + Piraclostrobina + Tiofanato Metílico (100) & 964,330 & $\mathrm{ABC}$ \\
4 & Fluxapiroxade (15) & 875,630 & $\mathrm{BC}$ \\
5 & Fluxapiroxade (25) & 1038,970 & $\mathrm{AB}$ \\
6 & Fluxapiroxade (50) & 952,540 & $\mathrm{ABC}$ \\
7 & Fluxapiroxade (75) & 1062,540 & $\mathrm{AB}$ \\
8 & Piraclostrobina (10) & 1103,930 & $\mathrm{~A}$ \\
\hline $\mathrm{CV}$ & & 12,66 &
\end{tabular}

${ }^{1}$ Médias seguidas pela mesma letra maiúscula não diferem entre si pelo teste de Duncan (Dc) ao nível de significância de 5\% 


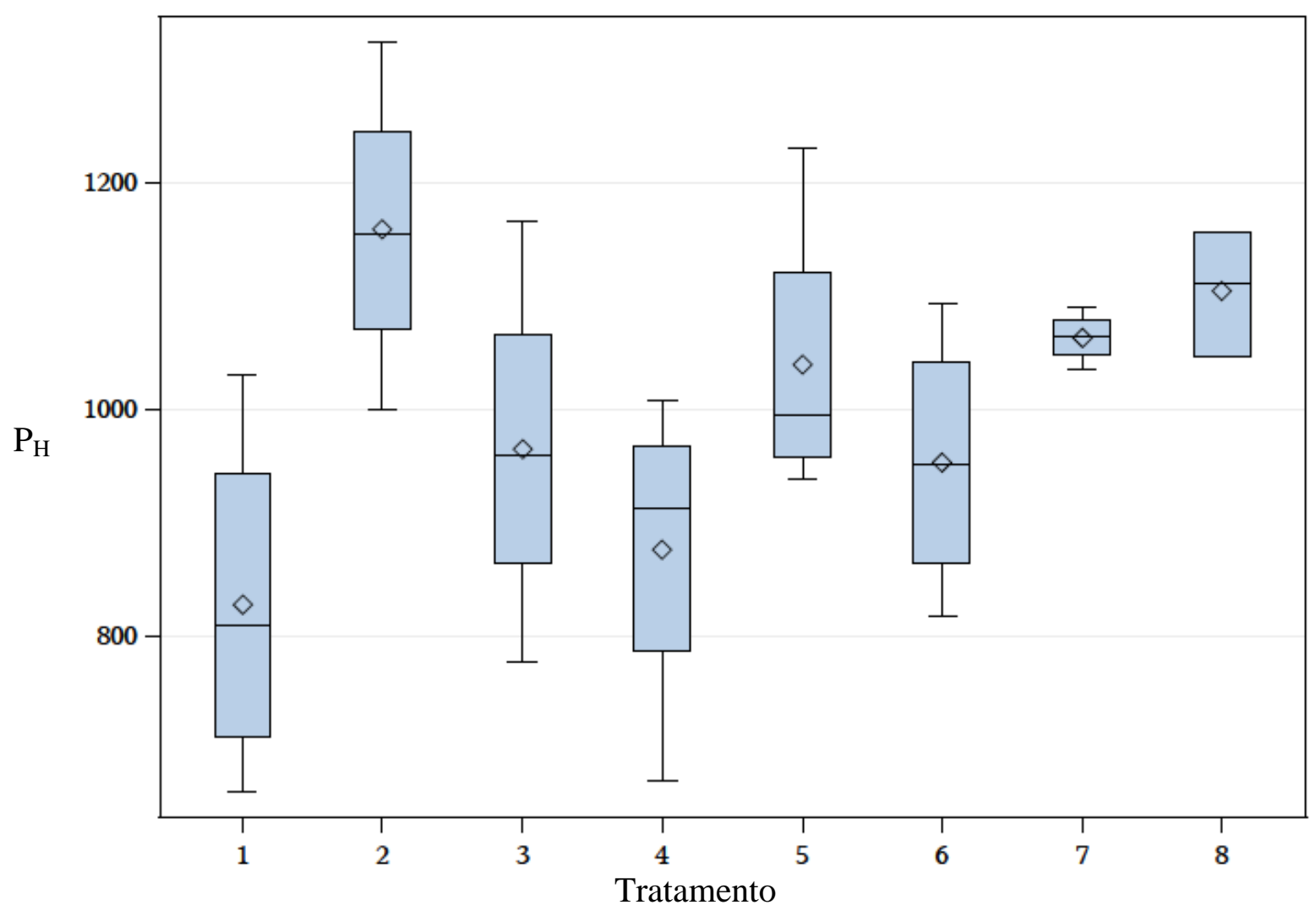

Figura 17 - Valores médios (losangos), mínimos, primeiro quartil, medianos, terceiro quartil e máximos referentes ao conteúdo de peróxido de hidrogênio $\left(\mathrm{H}_{2} \mathrm{O}_{2}\right)\left(\mathrm{P}_{\mathrm{H}}, \mu \mathrm{mol}\left[\mathrm{H}_{2} \mathrm{O}_{2}\right] \cdot \mathrm{g}^{-1}\right.$ de matéria fresca) aos 11 dias após a semeadura de soja. Laboratório de análise de sementes. Departamento de Produção Vegetal. Escola Superior de Agricultura “Luiz de Queiroz”. Universidade de São Paulo. 2013

\subsection{Catalase}

Os tratamentos com Fipronil + Piraclostrobina + Tiofanato Metílico e Fluxapiroxade (15 e $50 \mathrm{~g}$ por $100 \mathrm{~kg}$ de sementes) e Piraclostrobina apresentaram desempenho melhor que o Controle, mas não diferiram dos seguintes tratamentos: Fipronil e Fluxapiroxade (25 e 75 g por $100 \mathrm{~kg}$ de sementes) em termos da atividade da catalase aos 11 dias após a semeadura (Tabela 20 e Figura 18).

Existe uma ação conjunta da peroxidase e catalase, que reduz o risco de formação dos radicais $\mathrm{OH}^{-}$(radical hidroxila), um radical de elevada reatividade (SCANDALIOS, 1993). A catalase envolve a degradação de peróxido de hidrogênio a água e oxigênio, sendo um efetivo agente antioxidante em plantas (WILLEKENS et al., 1995). Contudo, a atividade desta enzima varia entre espécies, bem como, a duração do estresse em que a planta está sendo submetida (CHAPARZADEH et al., 2004). Estudos de Gao et al. (2008) demonstraram que o incremento da atividade da catalase esteve relacionada com alterações nas atividades 
das enzimas peroxidases e superóxido dismutase em Jatropha curcas como um mecanismo coordenado de desintoxicação celular.

A capacidade de manutenção, em níveis elevados da atividade da peroxidase e catalase sob condições de estresse ambiental, é essencial para a manutenção do equilíbrio entre a formação e a remoção de radicais livres do ambiente intracelular (ZHANG; KIRKHAM, 1996). A produção de radicais livres pelas plantas é altamente deletéria ao metabolismo.

Tabela 20 - Resultados: valores médios referentes à atividade da enzima catalase (CAT, $\mu$ mol $\left[\mathrm{H}_{2} \mathrm{O}_{2}\right] \cdot \mathrm{mg}[\text { proteína }]^{-1} \cdot \mathrm{min}^{-1}$ ) aos 11 dias após a semeadura de soja e ao coeficiente de variação $(\mathrm{CV}, \%)$. Laboratório de análise de sementes. Departamento de Produção Vegetal. Escola Superior de Agricultura "Luiz de Queiroz". Universidade de São Paulo. 2013

\begin{tabular}{clcc}
\hline $\mathrm{T}$ & Nome técnico (Dose $\left.-\mathrm{g}[\text { i.a.].[100kg sementes] }]^{-1}\right)$ & CAT & Dc $^{1}$ \\
\hline 1 & Controle & 32,360 & $\mathrm{~B}$ \\
2 & Fipronil (50) & 64,580 & $\mathrm{AB}$ \\
3 & Fipronil + Piraclostrobina + Tiofanato Metílico (100) & 90,010 & $\mathrm{~A}$ \\
4 & Fluxapiroxade (15) & 91,370 & $\mathrm{~A}$ \\
5 & Fluxapiroxade (25) & 67,920 & $\mathrm{AB}$ \\
6 & Fluxapiroxade (50) & 82,450 & $\mathrm{~A}$ \\
7 & Fluxapiroxade (75) & 60,350 & $\mathrm{AB}$ \\
8 & Piraclostrobina (10) & 76,070 & $\mathrm{~A}$ \\
\hline CV & & 31,86 &
\end{tabular}

${ }^{1}$ Médias seguidas pela mesma letra maiúscula não diferem entre si pelo teste de Duncan (Dc) ao nível de significância de 5\%. 


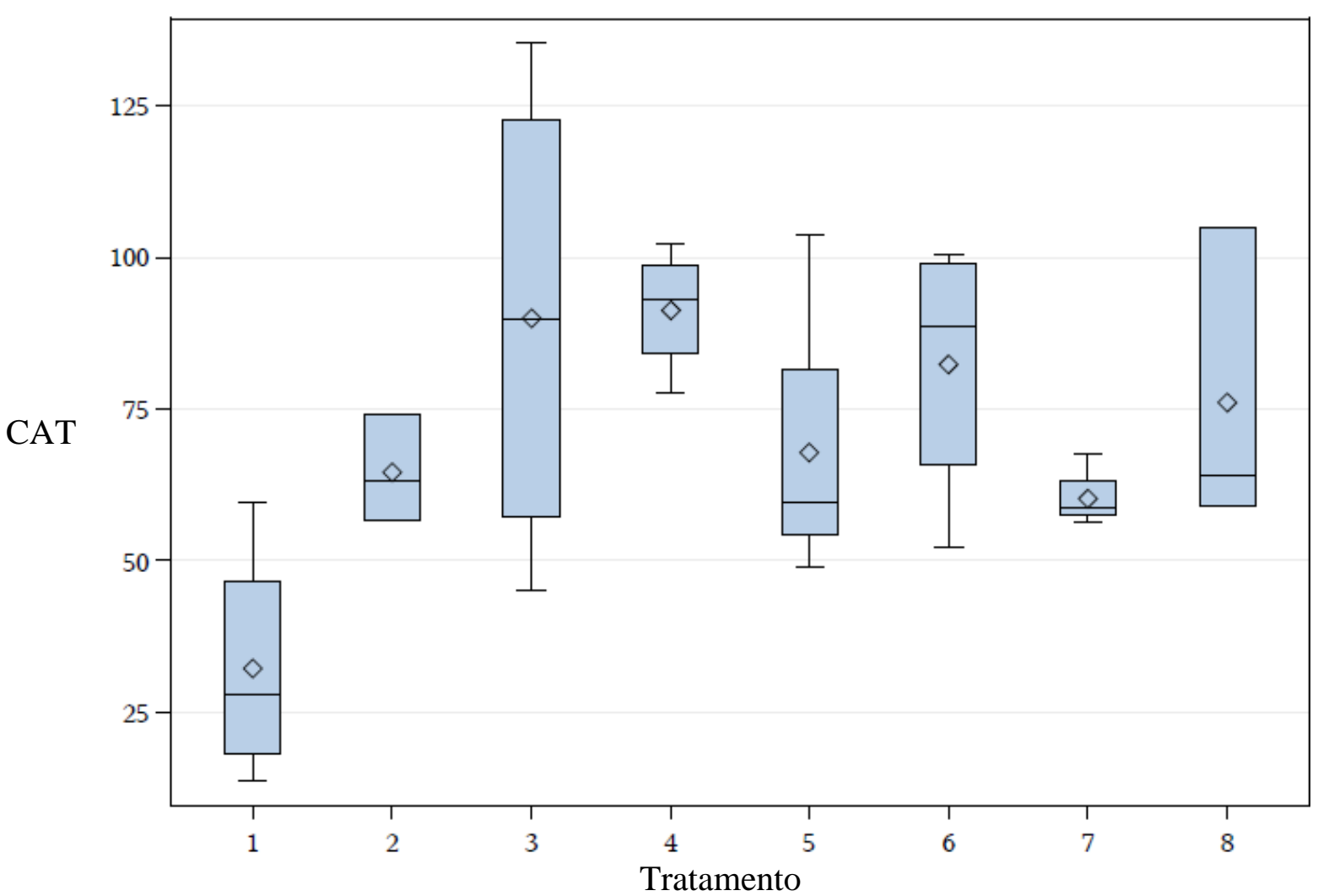

Figura 18 - Valores médios (losangos), mínimos, primeiro quartil, medianos, terceiro quartil e máximos referentes à atividade da enzima catalase $\left(\mathrm{CAT}, \mu \mathrm{mol}\left[\mathrm{H}_{2} \mathrm{O}_{2}\right] \cdot \mathrm{mg}[\text { proteína }]^{-1} \cdot \mathrm{min}^{-1}\right)$ aos 11 dias após a semeadura de soja. Laboratório de análise de sementes. Departamento de Produção Vegetal. Escola Superior de Agricultura “Luiz de Queiroz”. Universidade de São Paulo. 2013

\subsection{Peroxidação lipídica (MDA)}

Com relação à peroxidação de lipídeos, observa-se na Tabela 21 e Figura 19 que não houve diferença estática entre os tratamentos. No entanto, observou-se que em todos os tratamentos onde as sementes foram submetidas à aplicação de agroquímico ocorreu um estresse quando comparado ao tratamento Controle.

Além disso, apesar de ter sido observado maior atividade das enzimas antioxidantes no tramento de sementes utilizando Piraclostrobina, observa-se que o estresse foi mais acentuado nessas plantas, pois o produto utilizado nesse caso não possui formulação adequada para o tratamento de sementes.

Este estresse aparentemente gerado pelo tratamento das sementes, entretanto, não interferiu na germinação e desenvolvimento das plântulas de soja, conforme observado nas avaliações de germinação e vigor, discutidas anteriormente neste trabalho. 
Tabela 21 - Resultados: valores médios referentes à concentração de malondialdeído (MDA) $(C, \mathrm{mM}$ [MDA] por g de massa de matéria fresca) (peroxidação de lipídeos) aos 11 dias após a semeadura e ao coeficiente de variação $(\mathrm{CV}, \%)$. Laboratório de análise de sementes. Departamento de Produção Vegetal. Escola Superior de Agricultura "Luiz de Queiroz". Universidade de São Paulo. 2013

\begin{tabular}{llrc}
\hline $\mathrm{T}$ & Nome técnico (Dose $-\mathrm{g}\left[\right.$ i.a.].[100kg sementes] $\left.{ }^{-1}\right)$ & $\mathrm{C}$ & $\mathrm{Dc}^{1}$ \\
\hline 1 & Controle & 31,429 & $\mathrm{~A}$ \\
2 & Fipronil (50) & 33,010 & $\mathrm{~A}$ \\
3 & Fipronil + Piraclostrobina + Tiofanato Metílico (100) & 31,832 & $\mathrm{~A}$ \\
4 & Fluxapiroxade (15) & 32,828 & $\mathrm{~A}$ \\
5 & Fluxapiroxade (25) & 32,265 & $\mathrm{~A}$ \\
6 & Fluxapiroxade (50) & 36,167 & $\mathrm{~A}$ \\
7 & Fluxapiroxade (75) & 31,340 & $\mathrm{~A}$ \\
8 & Piraclostrobina (10) & 37,606 & $\mathrm{~A}$ \\
\hline
\end{tabular}

$\mathrm{CV}$

15,79

${ }^{1}$ Médias seguidas pela mesma letra maiúscula não diferem entre si pelo teste de Duncan (Dc) ao nível de significância de $5 \%$

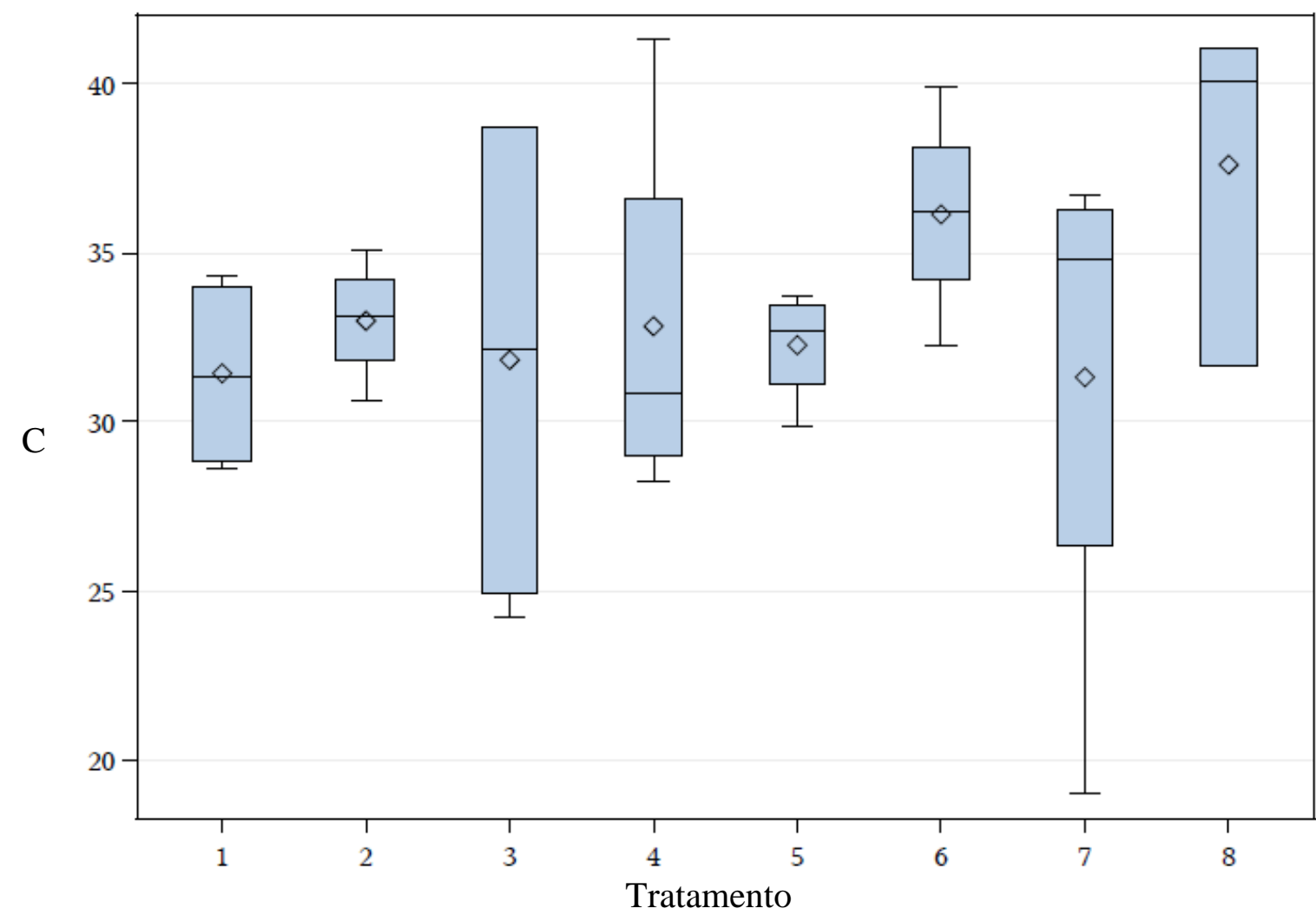

Figura 19 - Valores médios (losangos), mínimos, primeiro quartil, medianos, terceiro quartil e máximos referentes à concentração de malondialdeído (MDA) $(C, \mathrm{mM}$ [MDA] por g de massa de matéria fresca) (peroxidação de lipídeos) aos 11 dias após a semeadura de soja. Laboratório de análise de sementes. Departamento de Produção Vegetal. Escola Superior de Agricultura "Luiz de Queiroz". Universidade de São Paulo. 2013 


\section{CONCLUSÕES}

Com os resultados avaliados neste trabalho, conclui-se que o tratamento de sementes com os produtos testados constitui prática agronômica eficiente não só no que diz respeito ao controle de doenças e pragas veiculadas pelas sementes e presentes no solo, mas também apresenta benefícios no que diz respeito à fisiologia das plântulas de soja. Esses benefícios favorecem um melhor estabelecimento das plântulas no campo, assegurando uma população adequada na colheita.

Com base nos resultados discutidos, nota-se que não houve prejuízo à germinação ou vigor das sementes, aferido nos testes de índice de velocidade de germinação, envelhecimento acelerado, teste de frio, comprimento e massa de matéria seca de plântulas de soja e análise computadorizada de imagens.

O tratamento de sementes com Piraclostrobina favorece a atividade de enzimas antioxidantes e a assimilação de dióxido de carbono no desenvolvimento de plântulas de soja.

Em relação aos tratamentos com diferentes doses de Fluxapiroxade, parece haver também alguma tendência fisiológica que minimize o estresse oxidativo e favoreça a fotossíntese líquida, mas esta precisa ser estudada de forma mais aprofundada. 


\section{REFERÊNCIAS}

ALEXIEVA, V.; SERGIEV, I.; MAPELLI, S.; KARANOV, E. The effect of drought and ultraviolet radiation on growth and stress markers in pea and wheat. Plant, Cell and Environment, Oxford, v.24, p.1337-1344, 2001.

ALIYEV, J.A. Photosynthesis, photorespiration and productivity of wheat and soybean genotypes. Proceedings of the National Academy of Sciences of the USA, Washington, v.65, n.5/6, p.7-48, 2010.

ALIYEV, J. A.; MIRZOYEV, R. S. Photosynthesis and productivity of soybean [Glycine max (L.) Merrill]. Proceedings of the National Academy of Sciences of the USA, Washington, v.65, n.5-6, p.60-70, 2010.

ALMEIDA, A.S.; LAUXEN, R.L.; VILLELA, F.A.; MENEGHELLO, G.E.; TILLMANN, M.A.A. Physiological performance of wheat and barley seeds treated with bioactivator. American Journal of Experimental Agriculture, New Delhi, v.2, n.1, p.90-101, 2012.

AMMERMANN, E.; LORENZ, G.; SCHELBERGER, K.; MUELLER, B.; KIRSTGEN, R.; SAUTER, H. BAS $500 \mathrm{~F}$ - the new broad-spectrum strobilurin fungicide. In: BRIGHTON CROP PROTECTION CONFERENCE, PEST AND DISEASES, 2., 2000, Brighton. Proceedings... Brighton: BCPC, 2000. p.541-548.

ANDERSON, J.D.; BAKER, J.E. Deterioration of seeds during aging. Phytopathology, Saint Paul, v.73, n.2, p.321-325, 1983.

ANKE, T. The antifungal strobilurins and their possible ecological role. Canadian Journal Botany, Ottawa, v.73 (Suppl. 1), p.940-945, 1995.

AZEVEDO, R.A.; ALAS, R.M.; SMITH, R.M.; LEA, P.J. Response of antioxidant enzymes to transfer from elevated carbon dioxide to air and ozone fumigation, in the leaves and roots of wild-type and a catalase-deficient mutant of barley. Physiologia Plantarum, Copenhagen, v.104, p.280-292, 1998.

BARTLETT, D.W.; CLOUGH, J.M.; GODWIN, J.R.; HALL, A.A.; HAMER, M.; PARRDOBRZANSKI, B. The strobilurin fungicides. Pest Management Science, London, v.58, n.7, p.649-662, 2002.

BENATTO, J.C.; BARROS, C.S.A.A.; TAVARES, C.L.;RUFINO, C.A.; TUNES, L.V.M.; MENEGHELLO, G.E. Physiological quality of soybeans seeds treated with fungicide and coating with polymers. Revista Brasileira de Ciências Agrárias, Recife, v.7, n.2, p.269-273, 2012.

BRADFORD, M.M. A rapid and sensitive method for the qualification of microgram quantities of protein utilize the principle of protein dye binding. Analytical Biochemistry, New York, v.7, p.248-254, 1976.

BRAND, S.C.; ANTONELLO, L.M.; MUNIZ, M.F.B.; BLUME, E.; SANTOS, V.J.; REINIGER, L.R.S. Qualidade sanitária e fisiológica de sementes de soja submetidas a tratamento com bioprotetor e fungicida. Revista Brasileira de Sementes, Brasília, v.31, n.4, p.87-94, 2009. 
BRASIL. Ministério da Agricultura Pecuária e Abastecimento. Regras para análise de sementes. Brasília: MAPA/ACS, 2009. 399p.

BRENT, K.J.; HOLLOMON, D.K. Fungicide resistance in crop pathogens: how can it be managed? 2. ed. Bruxelas: FRAC, 2007. 60p.

CÂMARA, G.M.S.; HEIFFIG, L.S. Fisiologia, ambiente e rendimento da cultura da soja. In: CÂMARA, G.M.S. (Ed.). Soja: tecnologia de produção II. Piracicaba: ESALQ, LPV, 2000. cap. 5, p.81-119.

CAMARGO, M.B.P. Relações entre produtividade e exigências bioclimáticas. Visão Agrícola, Piracicaba, v.3, n.5, p.67-69, 2006.

CASTRO, P.R.C.; KLUGE, R.A.; PEPES, L.E.P. Manual de fisiologia vegetal: Fisiologia de cultivos. Piracicaba: Agronômica Ceres, 2008. 864p.

CHAPARZADEH, N.; AMICO, M. .; NEJAD, R. K.; IZZO, R.; IZZO, F. N. Antioxidative responses of Calendula officinalis under salinity conditions. Plant Physiology and

Biochemistry, Paris, v.42, n.9, p.695-701, 2004.

CHRISTENSEN, C.M. Germinability of seeds free of and invaded by storage fungi.

Proceedings Association of Official Seed Analysts, Lincoln, v.57, p.141-143, 1967.

CHRISTENSEN, C.M. Microflora and seed deterioration. In: ROBERTS, E.H. (Ed.).

Viability of seed. New York: Syracuse University Press, 1972. p.59-149.

CHRISTENSEN, C.M. Loss of viability in storage: microflora. Seed Science and Technology, Zurich, v.1, p.547-562, 1973.

CHRISTENSEN, C.M.; KAUFMAN, H.H. Grain storage: the role of fungi in quality loss. Minneapolis: University of Minnesota Press, 1969. 153p.

COMPANHIA NACIONAL DE ABASTECIMENTO. Acompanhamento da safra brasileira: grãos. Brasília, 2013. 30p. (12 levantamento).

COUTINHO, C.F.B.; TANIMOTO, S.T.; GALLI, A.; GARBELLINI, S.G.; TAKAYAMA, M.; AMARAL, R.B.; MAZO, L.H.; AVACA, L.A.; MACHADO, S.A.S. Pesticidas: mecanismo de ação, degradação e toxidez. Revista de Ecotoxicologia e Meio Ambiente, Curitiba, v.15, p.65-72, 2005.

DAN, L.G.M.; DAN, H.A.; PICCININ, G.G.; RICCI, T.T.; ORTIZ, A.H.T. Tratamento de sementes com inseticida e a qualidade fisiológica de sementes de soja. Revista Caatinga, Mossoró, v.25, n.1, p.45-51, 2012.

DELOUCHE, J.C. Planting seed quality. In: Proc. 1969. Beltwide Cotton Production Mechanization Conference. New Orleans, 1969. p.16-18.

DELOUCHE, J.C.; BASKIN, C.C. Accelerated aging techniques for predicting the relative storability of seed lots. Seed Science and Technology, Zurich, v.1, n.2, p.427-452, 1973. 
DIAS, M.A.N.; PINTO, T.L.F.; MONDO, V.H.V.; CICERO, S.M.; PEDRINI, L.G. Direct effects of soybean seed vigor on weed competition. Revista Brasileira de Sementes, Brasília, v.33, n.2, p.346-351, 2011.

EMBRAPA. Ecofisiologia da soja. Londrina: EMBRAPA Soja, 2007. 9p. (Circular Técnica, 48).

Tecnologias de produção de soja região central do Brasil 2011. Londrina: EMBRAPA Soja, 2010. 247p. (Sistemas de Produção, 14).

FAGAN, E.B.; DOURADO NETO, D.; VIVIAN, R.; FRANCO, R.B.; YEDA, M.P.; MASSIGNAM, L.F.; OLIVEIRA, R.F.; MARTINS, K.V. Efeito da aplicação de Piraclostrobina na taxa fotossintética, respiração, atividade da enzima nitrato redutase e produtividade de grãos de soja. Bragantia, Campinas, v.69, n.4, p.771-777, 2010.

FAGAN, E.B. A cultura da soja: modelo de crescimento e aplicação de estrobilurina. 2007. 84 p. Tese (Doutorado em Fitotecnia) - Escola Superior de Agricultura "Luiz de Queiroz", Universidade de São Paulo, Piracicaba, 2008.

FESSEL, S.A.; PANOBIANCO, M.; SOUZA, C.R.; VIEIRA, R.D. Teste de condutividade elétrica em sementes de soja armazenadas sob diferentes temperaturas. Bragantia, Campinas, v.69, n.1, p.207-214, 2010.

FIESP. Outlook Fiesp 2023: projeções para o agronegócio brasileiro. São Paulo: FIESP, 2013. 115p.

FLOSS, E. Fisiologia das Plantas Cultivadas: o estudo do que está por trás do que se vê. 5. Ed. Passo Fundo: UFP, 2011. 751p.

FRAC. FRAC Code List 2013: Fungicides sorted by mode of action. 2013. 10p.

FRANÇA NETO, J.B.; HENNING, A.A. Qualidade fisiológica e sanitária de sementes de soja. Londrina: EMBRAPA, 1984. 39p. (Circular Técnica, 9).

GAO, S.; YAN, R.; CAO, M.; YANG, W.; WANG, S.; CHEN, F. Effects of copper on growth, antioxidant enzymes and phenylalanine ammonia-lyase activities in Jatropha curcas L. seedling. Plant Soil Environment, Orono, v.54, p.117-22, 2008.

GLAAB, J.; KAISER, W.M. Increased nitrate reductase activity in leaf tissues after application of the fungicide Kresoxim-methyl. Planta, Berlin, v.207, n.3, p.442-448, 1999.

GHINI, R.; KIMATI, H. Resistência de fungos a fungicidas. Jaguariúna: EMBRAPA Meio Ambiente, 2000. 78p.

GOMES JÚNIOR, R.; GRATÃO, P.L.; GAZIOLA, S.A.; MAZZAFERA, P.; LEA, P.J.; AZEVEDO, R.A. Selenium-induced oxidativa stress in coffee cell suspension cultures. Functional Plant Biology, Victoria, v.34, p.449-456, 2007.

GOULART, A.C.P. Tratamento de sementes de soja com fungicidas: recomendações técnicas. Dourados: EMBRAPA CPAO, 1998. 32 p. (Circular Técnica, 8). 
GOULART, A.C.P.; PAIVA, E.A.; ANDRADE, P.J.M. Qualidade sanitária de sementes de soja (Glycine max (L.) Merrill) produzidas no Mato Grosso do Sul. Fitopatologia Brasileira, Brasília, v.20 (suplemento). p.292. 1995.

HEATH, R.L.; PACKER, L. Photoperoxidation in isolated chloroplasts. I. Kinetics and stoichiometry of fatty acid peroxidation. Archives of Biochemistry and Biophysics, New York, v.125, p.189-198, 1968.

HENNING, A.A. Patologia de sementes. Londrina: EMBRAPA-CNPSo, 1994. (Documentos, 90).

HENNING, A.A. Patologia e tratamento de sementes: noções gerais. Londrina: Embrapa Soja, 2005. 51p. (Documentos, 264).

HENNING, A.A.; YUYAMA, M.M. Levantamento da qualidade sanitária de sementes de soja produzidas em diversas regiões do Brasil, entre as safras 1992/93 e 1996/97. Revista Brasileira de Sementes, Londrina, v.21, n.1, p.18-26, 1999.

HENNING, A.A.; FRANÇA NETO, J.B.; KRZYZANOWSKI, F.C.; LORINI, I.

Importância do tratamento de sementes de soja com fungicidas na safra 2010/2011, ano de "La Niña". Londrina: Embrapa Soja, 2010. 8p. (Circular Técnica, 82).

HOFFMASTER, A.L.; FUJIMURA, K.; MACDONALD, M.B.; BENNET, M.A. An automated system for vigor testing three-day-old soybean seedlings. Seed Science and Technology, Zurich, v.31, n.3, p.701-713, 2003.

JYIOTI; MALIK, C.P. Seed deterioration: a review. International Journal of Life Sciences Biotechnology and Pharma Research, Hyderabad, v.2, n.3, p.374-385, 2013.

KANDIL, A.A.; SHARIEF, A.E.; SHETEIWY, M.S. Effect of seed storage periods, conditions and materials on seed quality of some soybean cultivars. International Journal of Agriculture Sciences, Brooklyn, v.5, n.1, p.339-346, 2013.

KÖHLE, H.; GROSSMANN, K.; RETZLAFF, G.; AKERS, A. Physiologische Einflüsse des neuen Getreidefungizides Juwel auf die Ertragsbildung. Gesunde Pflanzen, Berlin, v.49, p.267-271, 1997.

KÖHLE, H.; GROSSMANN, K.; JABS, T.; GERHARD, M.; KAISER, W.; GLAAB, J.; CONRATH, U.; SEEHAUS, K.; HERMS, S. Physiological effects of the strobilurin fungicide F500 on plants. In: Modern Fungicides and Antifungal Compounds III: $13^{\text {th }}$ International Reinhardsbrunn Symposium, 2003, Germany. Proceeding... Germany: IRS, 2003.

KRAUS, T.E.; MCKERSIE, B.D.; FLETCHER, R.A. Paclobutrazol-induced tolerance of wheat leaves to paraquat may involve increased antioxidant enzyme activity. Journal of Plant Physiology, Stuttgart, v.145, n.4, p.570-576, 1995.

LIMA FILHO, O.F.; MALAVOLTA, E.; CABRAL, C.P. Avaliação preliminar de um medidor portátil de clorofila como ferramenta para o manejo da adubação nitrogenada do cafeeiro. Arquivos de Biologia e Tecnologia, Curitiba, v.40, n.3, p.642-650, 1997.

MAGUIRE, J.D. Speed of germination-aid in relation evaluation for seedling emergence vigor. Crop Science, Madison, v.2, p.176-177, 1962. 
MARCOS FILHO, J. Fisiologia de sementes de plantas cultivadas. Piracicaba: Fealq, 2005. 495p.

MARCOS FILHO, J. Testes de vigor: importância e utilização. In: KRZYZANOWSKI, F.C.; VIEIRA, R.D.; FRANÇA NETO, J.B. (Ed.). Vigor de sementes: conceitos e testes. Londrina: ABRATES, cap. 1, p.1-21. 1999.

MARCOS FILHO, J.; KIKUTI, A.L.P.; LIMA, L.B. Métodos para avaliação do vigor de sementes de soja, incluindo a análise computadorizada de imagens. Revista Brasileira de Sementes, Brasília, v.31, n.1, p.102-112, 2009.

MBOFUNG, G.C.Y; GOGGI, A.S.; LEANDRO, L.F.S.; MULLEN, R.E. Effects of storage temperature and relative humidity on viability and vigor of treated soybean seeds. Crop Science, v.53, p.1086-1095, 2013.

MENTEN, J.O.; MORAES, M.H.D. Tratamento de sementes: histórico, tipos, características e benefícios. Informativo ABRATES, Brasília, v.20, n.3, p.52-71, 2010.

MIHARA, M.; UCHIYAMA, M.; FUKAZAWA, K. Thiobarbituric acid value on fresh homogenate of rat as a parameter of lipid peroxidation in aging, $\mathrm{CCl}_{4}$ intoxication, and vitamin E deficiency. Biochemical Medicine, v.23, p.302-311, 1980.

MORAN, R. Formulae for determination of chlorophyll as pigments extracted with Ndimethylformamide. Plant Physiology, Rockville, v.69, p.1376-1381, 1982.

MORAN, R.; PORATH, D. Chlorophyll determination in intact tissues using N, NDimethylformamide. Plant Physiology, Rockville, v.65, p.478-479, 1980.

NDIMANDE, B.N.; WIEN, H.C.; KUENEMAN, E.A. Soybean seed deterioration in the tropics. I. The role of physiological factors and fungal pathogens. Field Crops Research, Amsterdam, v.4, p.113-121, 1981.

NEERGAARD, P. Seed Pathology. New York: John Wiley and Sons. 1977. 839p.

PARREIRA, D.F.; NEVES, W.S.; ZAMBOLIM, L. Resistência de fungos a fungicidas inibidores de quinona. Revista Trópica - Ciências Agrárias e Biológicas, Chapadinha, v.3, n.2, p.24-34, 2009.

PASSARDI, F.; COSIO, C.; PENEL, C.; DUNAND, C. Peroxidases have more functions than a Swiss army knife. Plant Cell Reports, Berlin, v.24, p.255-265, 2005.

POPINIGIS, F. Fisiologia da semente. Brasília: AGIPLAN, 1977. 289p.

PRITCHARD, S.G.; JU, Z.; SANTEN, E.; QIU, J.; WEAVER, D.B.; PRIOR, S.A.;

ROGERS, H.H. The influence of elevated $\mathrm{CO}_{2}$ on the activities of antioxidative enzymes in two soybean genotypes. Australian Journal of Plant Physiology, Washington, v.27, p.10611068, 2000.

RIGON, L. Anuário brasileiro da soja. Santa Cruz do Sul: Gazeta Santa Cruz, 2007. 136p. 
RODRIGUES, M.A.T. Avaliação do efeito fisiológico do uso de fungicidas na cultura da soja. 2009, 198p. Tese (Doutorado em Fitotecnia) - Escola Superior de Agricultura "Luiz de Queiroz”, Universidade de São Paulo, Piracicaba, 2009.

SANTOS, J.F.; ALVARENGA, R.O.; TIMÓTEO, T.S.; CONFORTO, E.C.; MARCOS FILHO, J.; VIEIRA, R.D. Avaliação do potencial fisiológico de lotes de sementes de soja. Revista Brasileira de Sementes, Brasília, v.33, n.4 p.743-751, 2011.

SAS INSTITUTE. The SAS system, release 9.3. Cary, 2010.

SCANDALIOS, J.G. Oxygen stress and superoxide dismutase. Plant Physiology, Washington, v.101, p.7-12, 1993.

SCHUCH, L.O.B.; KOLCHINSKI, E.M.; FINATO, J.A. Qualidade fisiológica da semente e desempenho de plantas isoladas em soja. Revista Brasileira de Sementes, Londrina, v.31, n.1, p.144-149, 2009.

SCHUCH, L.O.B.; NEDEL, J.L.; ASSIS, F.N.; MAIA, M.S. Emergência em campo e crescimento inicial de aveia preta em resposta ao vigor das sementes. Revista Brasileira de Agrociência, Londrina, v.6, n.2, p.97-101, 2000.

SCHUCH, L.O.B.; NEDEL, J.L.; ASSIS, F.N. Vigor de sementes e análise de crescimento de aveia preta. Scientia Agricola, Piracicaba, v.57, n.2, p.305-312, 2000.

SUDISHA, J.; AMRUTHESH, K.H.; DEEPAK, S.A.; SHETTY, N.P.; SAROSH, B.R.; SHETTY, H.S. Comparative efficacy of strobilurin fungicides against downy mildew disease of pearl millet. Pesticide Biochemistry and Physiology, San Diego, v.81, p.188-197, 2005.

SUDISHA, J.; NIRANJANA, S.R.; SUKANYA, S.L.; GIRIJAMBA, R.; LAKSHMI-DEVI, N.; SHETTY, H.S. Relative efficacy of strobilurin formulations in the control of downy mildew of sunflower. Pesticide Biochemistry and Physiology, San Diego, v.83, p.461-470, 2010.

TAIZ, L.; ZEIGER, E. Plant physiology. 5. ed. Sunderland: Sinauer Associates, 2010. 782p.

TATIPATA, A. Effect of seed moisture content packaging and storage period on mitochondria inner membrane of soybean seed. Journal of Agricultural Technology, Bangkok, v.5, n.1, p.51-64, 2009.

TEKRONY, D.M.; EGLI, D.B. Relationship of seed vigor to crop yield: a review. Crop Science, Madison, v.31, p.816-822, 1991.

TEKRONY, D.M.; EGLI, D.B.; WICKHAM, D.A. Corn seed vigor on no-tillage field performance. II. Plant growth and grain yield. Crop Science, Madison, v.29, p.1528-1531, 1989.

USDA. World Agricultural Production. 2013. 25 p. (Circular Series).

VANZOLINI, S.; CARVALHO, N.M. Efeito do vigor de sementes de soja sobre o seu desempenho em campo. Revista Brasileira de Sementes, Brasília, v.24, n.1, p.33-41, 2002. 
VENÂNCIO, W.S.; RODRIGUES, M.T.R.; BEGLIOMINI, E.; SOUZA, N.L. de. Physiological effects of strobilurin fungicides on plants. Ciências Exatas e da Terra, Ciências Agrárias e Engenharia, Ponta Grossa, v.9, n.3, p.59-68, 2003.

VERNETTI, F.J. (Coord.). Soja: planta, clima, pragas, moléstias e invasoras. Campinas: Fundação Cargill, 1983. 463p.

VIEIRA, R.D.; BITTENCOURT, S.R.M.; PANOBIANCO, M. Seed vigour: an important component of seed quality in Brazil. Seed Testing International, Zurich, n.126, p.21-22, 2003.

WALL, M.T.; MCGEE, D.C.; BURRIS, J.S. Emergence and Yield of Fungicide-Treated Soybean Seed Differing in Quality. Alliance of Crop, Soil and Environmental Science Societies, Ames, v.75, n.6, p.969-973, 1983.

WEISZ, R.; COWGER, C.; AMBROSE, G.; GARDNER, A. Multiple Mid-Atlantic field experiments show no economic benefit to fungicide application when fungal disease is absent in winter wheat. Disease Control and Pest Management, Ames, v.101, n.3, p.323-333, 2011.

WILLEKENS, H.; INZE, D.; VAN MONTAGU, M.; VAN CAMP, W. Catalase in plants. Molecular Breeding, Oxford, v.1, n.3, p.207-228, 1995.

YAN, Y.; GONG, W.; YANG, W.; WAN, Y.; SHEN, X.; SHEN, Z.; WANG, L. Seed treatment with uniconazole powder improves soybean seedling growth under shading by corn in relay strip intercropping system. Plant Production Science, Tokio, v.13, n.4, p.367-374, 2010.

YASSEN, Y.M.; BARRINGER, S.A.; SPLITTSTOESSER, W.E.; CONSTANZA, S. The role of seed coats in seed viability. The Botanical Review, New York, v.60, n.4, p.426-435, 1994.

YORINORI, J.T. Doenças de soja no Brasil. In: Fundação Cargill. A Soja no Brasil Central. 3. Ed. Campinas: Fundação Cargill, 1986. Cap. 8.

YORINORI, J.T. Importância do aspecto sanitário em programas de produção de sementes. In: SIMPÓSIO BRASILEIRO DE PATOLOGIA DE SEMENTES, 3., Lavras, 1888. Anais... Campinas, Fundação Cargill, 1988, p.24-47.

ZAMBOLIM, L.; VENÂNCIO, W.S.; OLIVEIRA, S.H.F. Manejo da resistência de fungos a fungicidas. Viçosa: UFV, 2007. 168p.

ZHANG, J.; KIRKHAM, M.B. Lipid peroxidation in sorghum and sunflower seedlings as affected by ascorbic acid, benzoic acid, and propyl gallate. Journal of Plant Physiology, Stuttgart, v.149, p.489-493, 1996.

ZUCARELI, C. Teste de deterioração controlada para avaliação do vigor de sementes de milho (Zea mays L.). 2002. 125p. Dissertação (Mestrado em Agronomia) - Faculdade de Ciências Agronômicas, Universidade Estadual Paulista "Júlio de Mesquita Filho", Botucatu, 2002. 
ANEXOS 
ANEXO 1

a

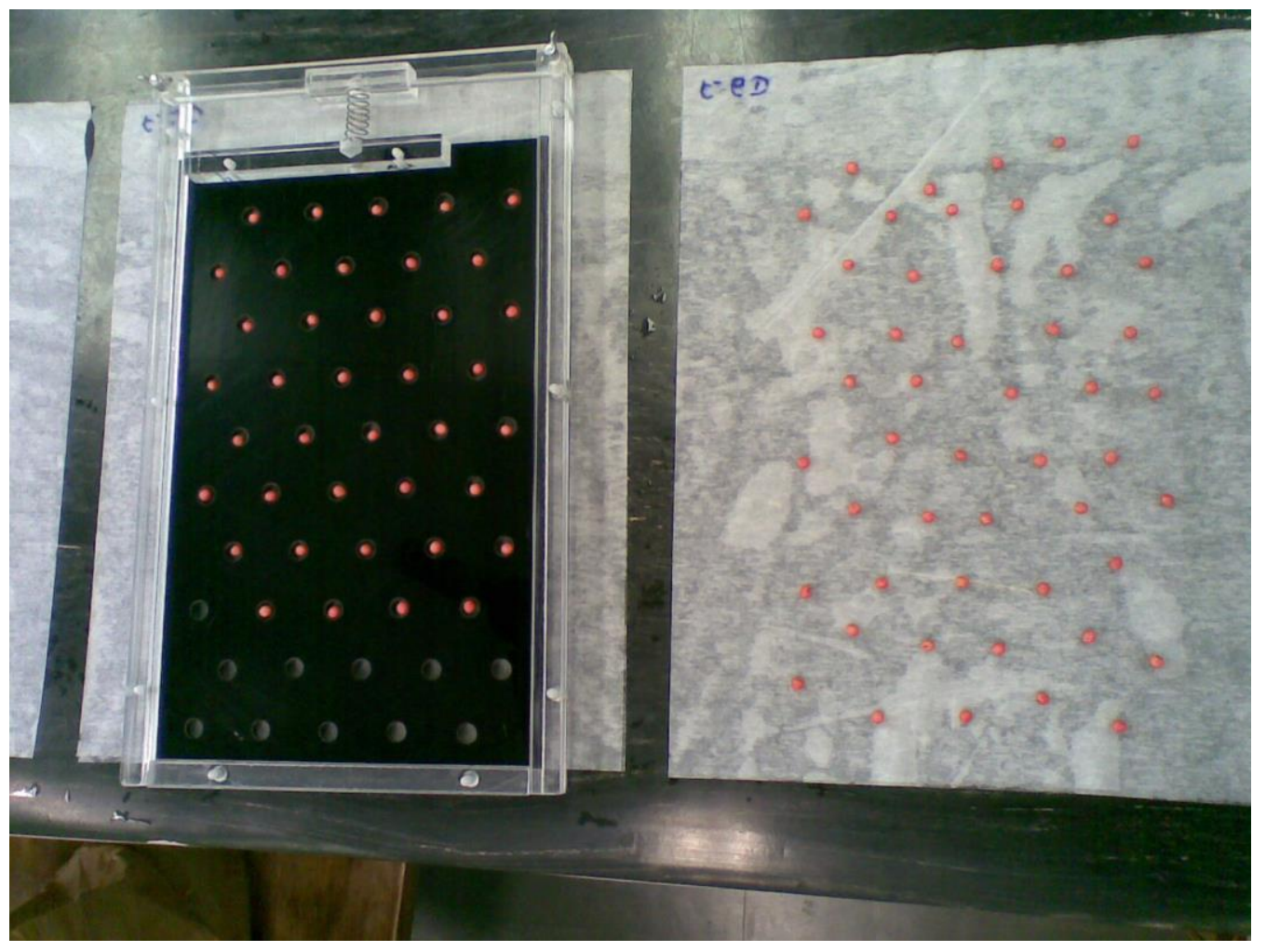

b

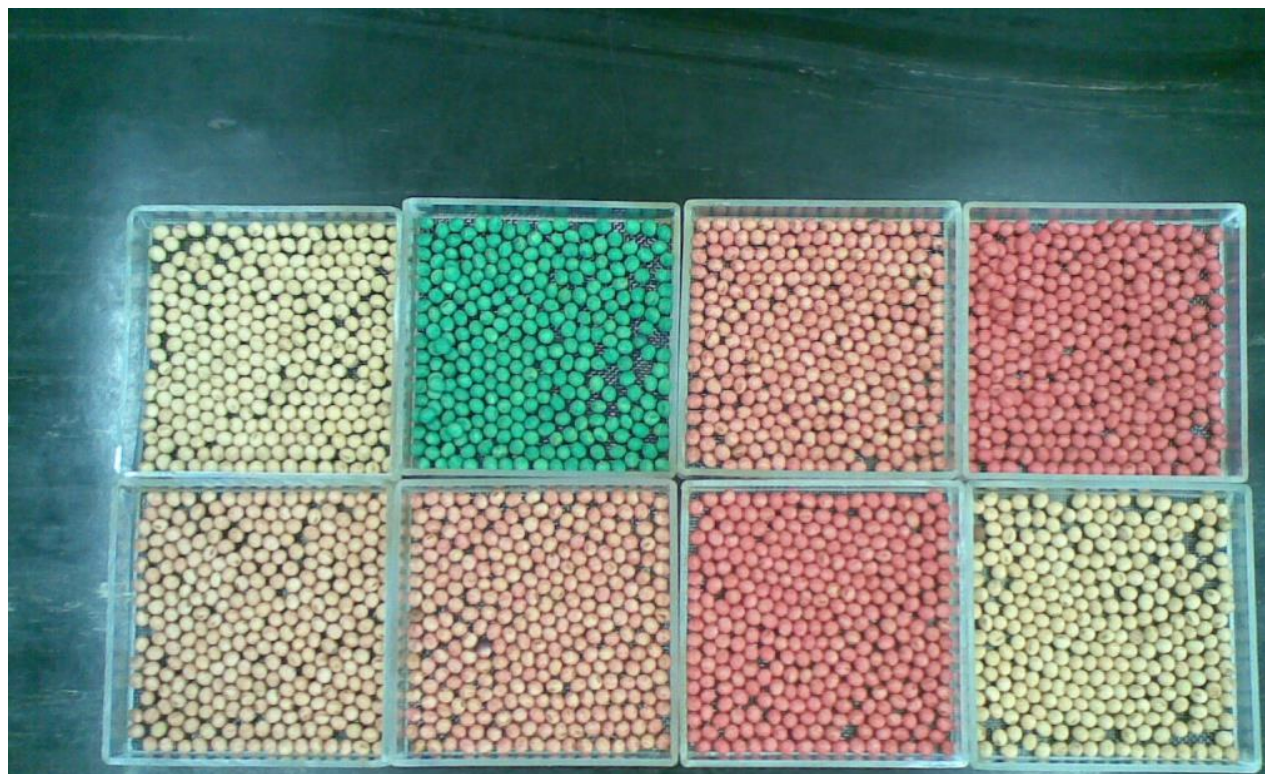

Figura 20 - (A) Teste de germinação e (B) Teste de vigor (envelhecimento acelerado). Laboratório de análise de imagem. Departamento de Produção Vegetal. Esalq, USP. 2013 


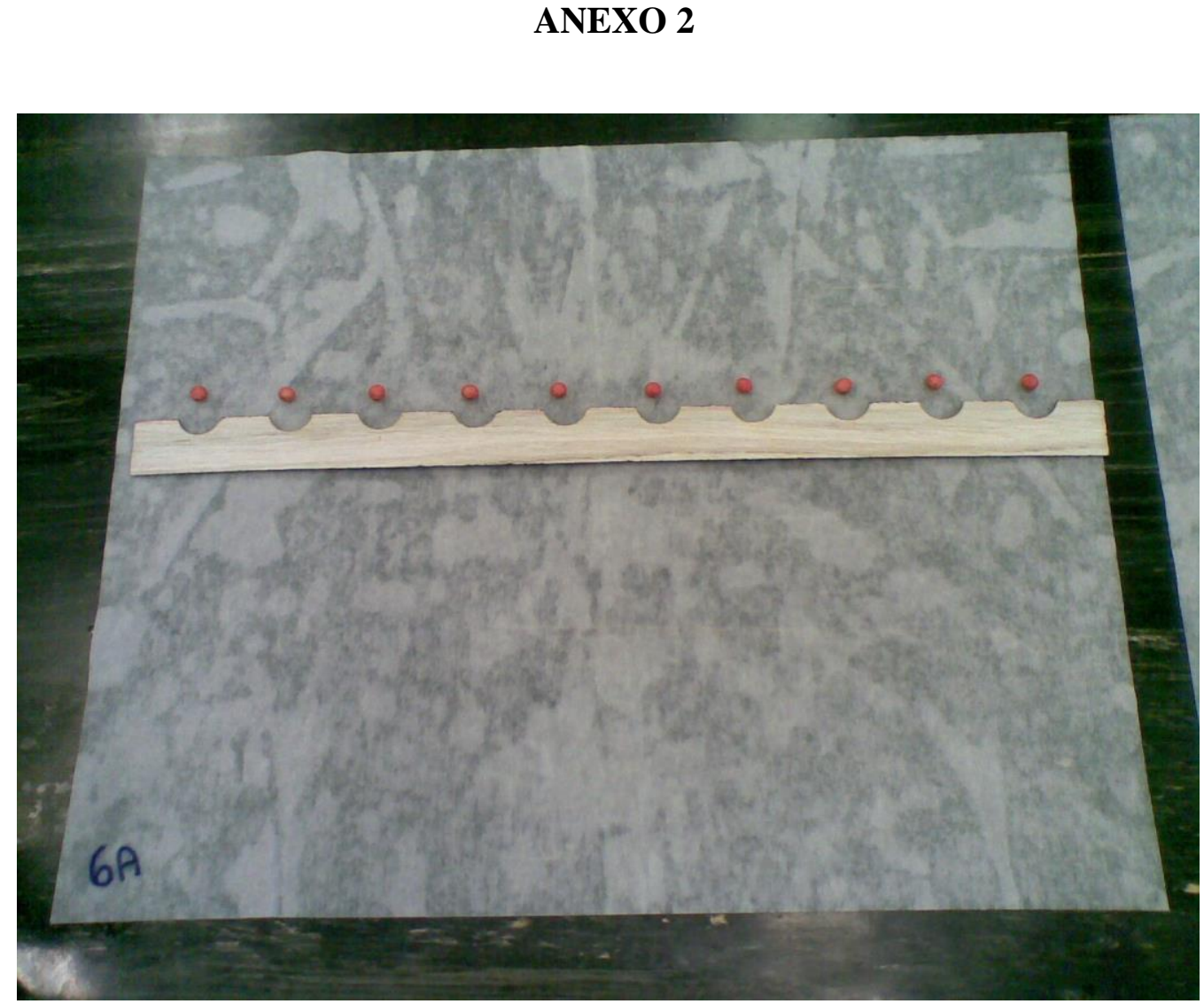

Figura 21 - Teste de vigor (comprimento de plântula). Laboratório de análise de imagem. Departamento de Produção Vegetal. Esalq, USP. 2013 


\section{ANEXO 3}

$\mathrm{T}$

1

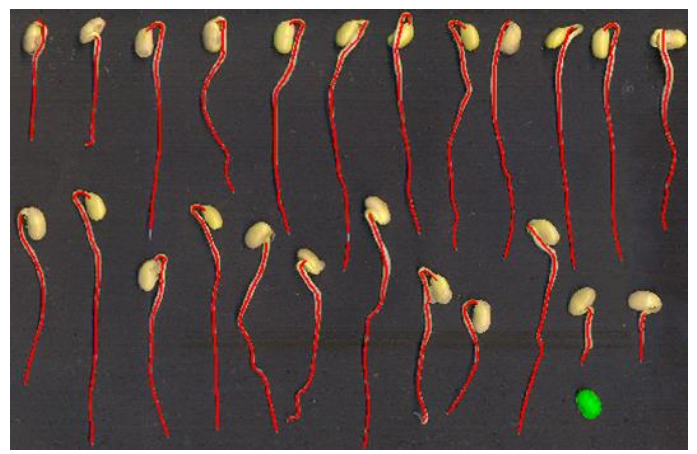

2

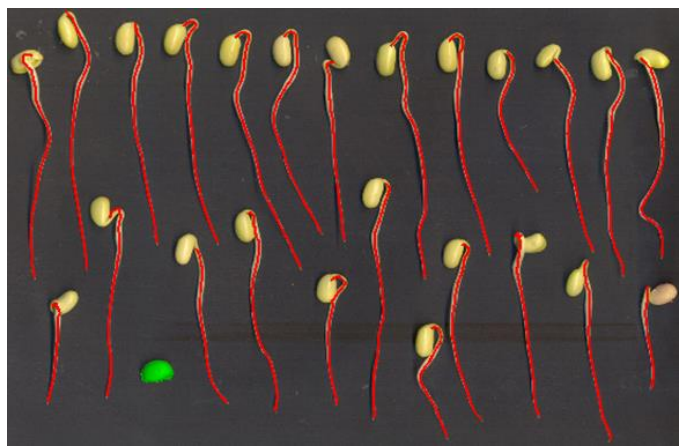

3

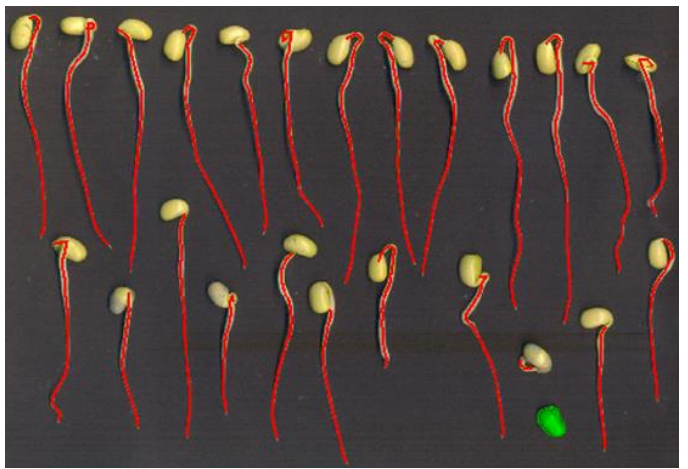

4

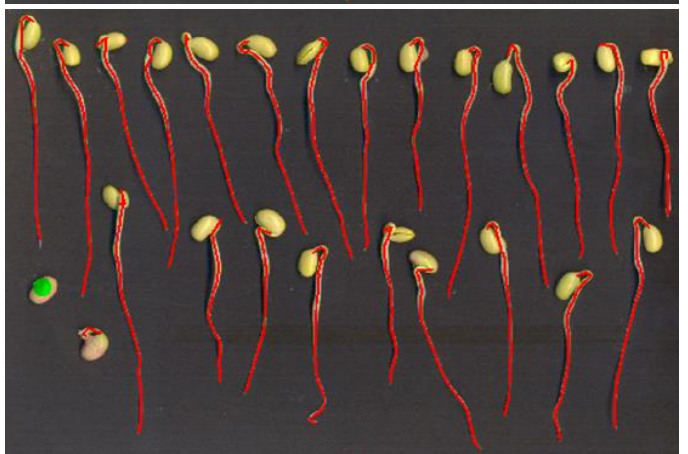

$\mathrm{T}$

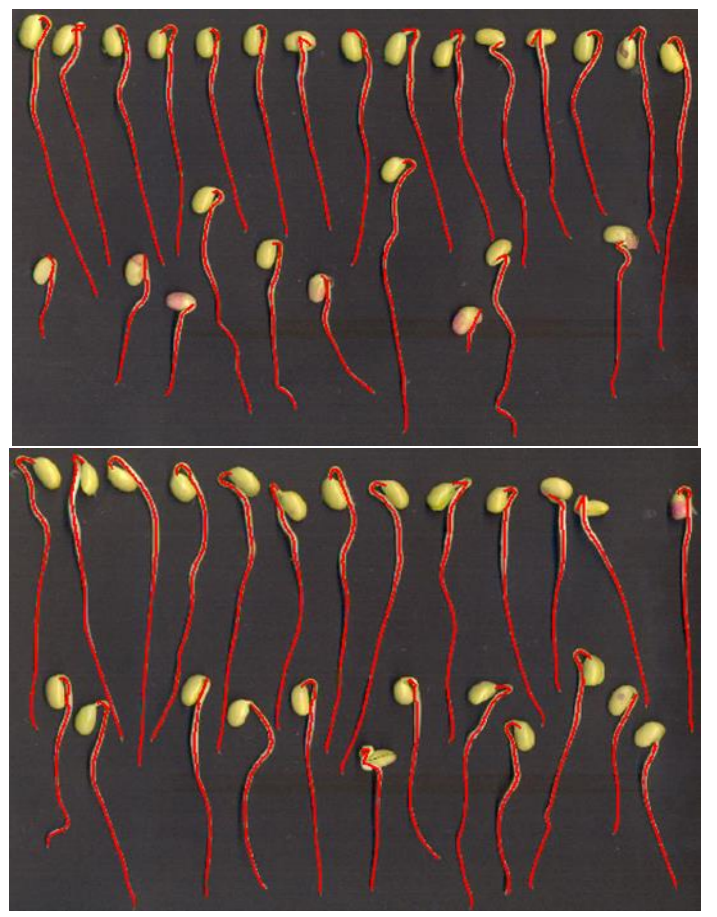

7

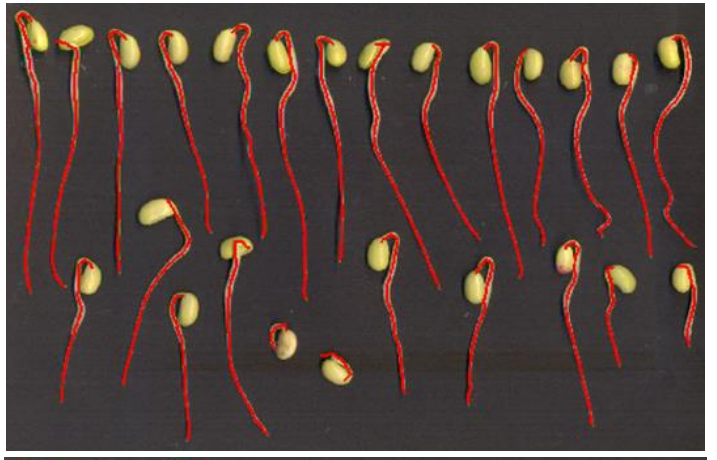

8

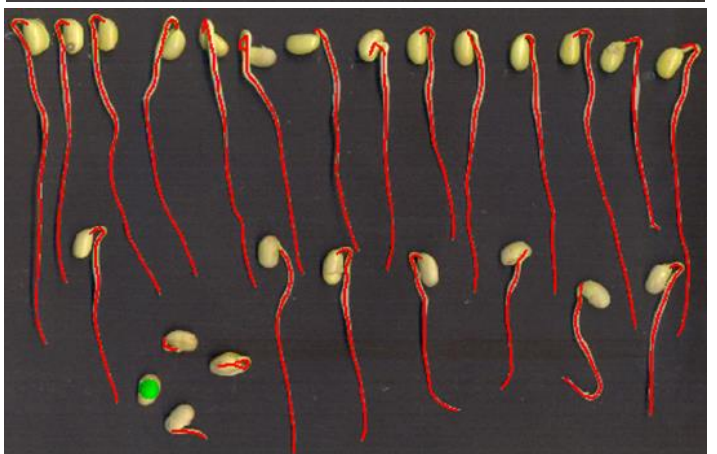

Figura 22 - Resultados da análise computadorizada de imagens por intermédio do Software SVIS (Seed Vigor Image System) referentes à primeira parcela dos tratamentos (T): (1) 830 (índice de crescimento), 848 (índice de uniformidade) e 835 (índice de vigor), (2) 833, 864 e 842, (3) 821, 854 e 830, (4) 947, 889 e 929, (5) 911, 894 e 905, (6) 1000, 917 e 975, (7) 818, 884 e 837 e (8) 890, 851 e 878. Laboratório de análise de imagem. Departamento de Produção Vegetal. Esalq, USP. 2013 